Journal of the Scientific Agricultural Society of Finland Vol. 51: $79-148,1979$

Maataloustieteellinen Aikakauskirja

\title{
DRIED POULTRY MANURE AS A FEED INGREDIENT FOR DAIRY COWS
}

Selostus: Kananlanta lypsylehmien rehuna

\author{
MATTI NÄSI \\ Department of Animal Husbandry \\ University of Helsinki \\ SF-00710 Helsinki 71, Finland
}

To BE PRESENTED, WITH THE PERMISSION OF

the Faculty of Agriculture and Forestry OF THE UNIVERsity OF Helsinki, For PUblic CRITICISM IN AUditoriUM VIIKKI B3 ON JUNE 15, 1979 Ат 12 о'сLоск. 


\section{Preface}

The present investigation was carried out at the Department of Animal Husbandry, University of Helsinki and at the Department of Animal Hygiene, College of Veterinary Medicine.

I wish to express my gratitude to my teacher, Professor Esko Poutiainen and I am greatly indebted to him for his continual interest, encouragement and criticism in the progress of this work. I extend also sincere thanks to Professor KaArlo Kallela for many stimulating discussions and constructive suggestions. It is my pleasure to thank Dr. Maija-LiISA Salo, Dr. LiIsa SyrJäLÄ and Dr. Eero TANhUANpää for checking the manuscript and giving me valuable constructive criticism.

My colleagues have been interested in this work and have given their help on many occassions during the investigation. I would like to experss my gratitude for this assistance. The lingvistic revision has been made by Dr. Kathleen Ahonen and Miss Diane Barnes, who are gratefully acknowledged.

The study was supported by grants from the August Joнannes and Aino Tiura Agricultural Research Foundation and the Finnish Cultural Foundation. I am grateful to the Scientific Agricultural Society of Finland for including this study in their series of publication.

Finally, I wish to thank my wife PIRJo and daughter ANNA for their encouraging support and never failing patience during my work. 



\section{CONTENTS}

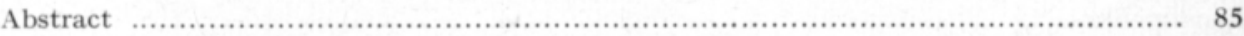

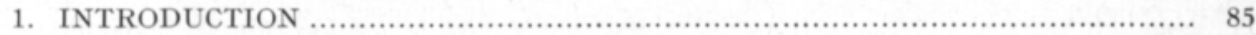

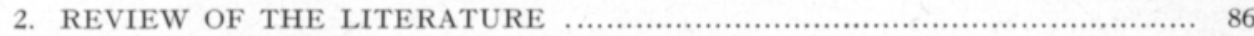

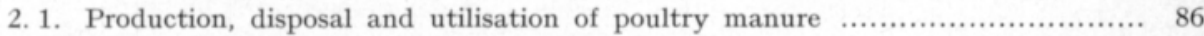

2. 1. 1. Production of poultry manure .......................................... 86

2. 1. 2. Disposal and utilisation of poultry manure ............................ 87

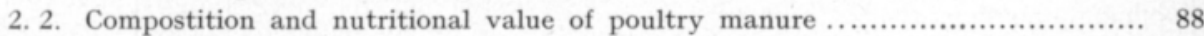

2. 2. 1. Composition and factors affecting the composition of poultry manure 88

2. 2. 2. Chemical composition of poultry manure ............................... 88

2. 2.3. Nitrogen components of poultry manure …............................. 89

2. 2. 4. Digestibility of poultry manure ....................................... 89

2. 2. 5. Energy value of poultry manure ......................................... 90

2. 3. Utilisation of poultry manure as feed for animals ............................. 90

2. 3. 1. Poultry manure and uric acid as a nitrogen source for ruminants ..... 90

2. 3. 2. DPM as protein supplement for lactating cows ........................ 91

2. 3. 3. Feeding DPM for beef and sheep production ......................... 92

2. 3. 4. Feeding recycled wastes to non-ruminants ............................ 93

2. 4. Health aspects of recycling poultry manure .................................. 94

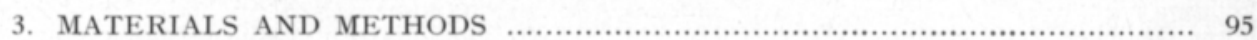

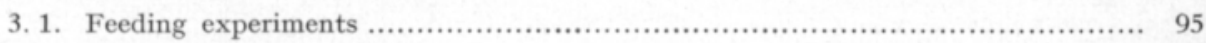

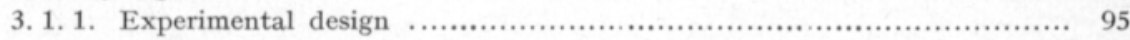

3. 1. 2. Experimental feeds and feeding ........................................ 96

3. 1. 3. Sampling and analyses ................................................... 96

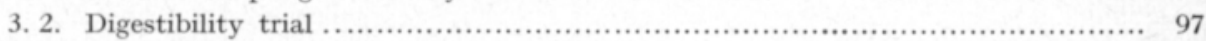

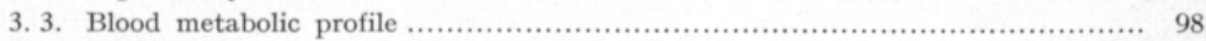

3. 4. Metabolism trials ...................................................................... 98

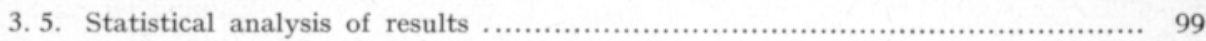

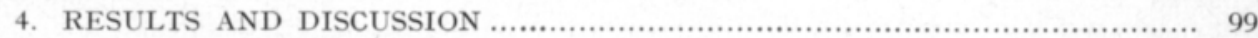

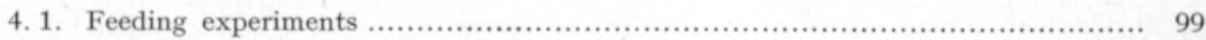

4.1.1. Feed composition and consumption ..................................... 99

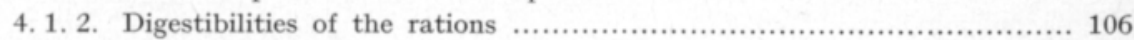

4. 1. 3. Milk yield and feed utilisation ............................................ 107

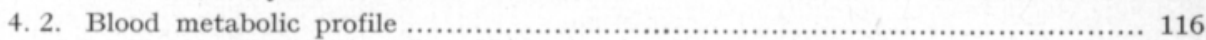

4. 3. Rumen fermentation .................................................................... 123

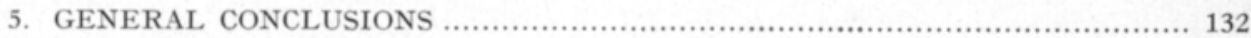

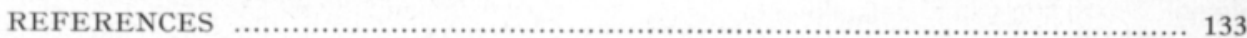

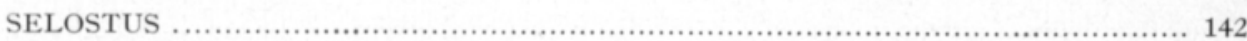

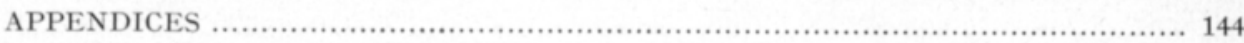



NÄsI, M. 1979. Dried poultry manure as a feed ingredient for dairy cows J. Scient. Agric. Soc. Finl. 51: 79-000.

\begin{abstract}
The study investigated the utilisation of dried poultry manure as a protein source for lactating cows and its influence on the blood metabolic profile and rumen fermentation.

Two consecutive feeding trials were carried out for the comparison of dried poultry manure (DPM) $20 \%$, soybean meal (SBM) $10 \%$ and urea $1.5 \%$ as protein supplement in a concentrate mixture. Eighteen cows were used in each of the two experiments. The experimental period was 13 weeks in Expt. 1 and 15 weeks in Expt. 2. The apparent DM digestibilities of the DPM, SBM and UREA rations were 69.9, 72.0 and $74.0 \%$ $(\mathrm{P}<0.05)$ and crude protein digestibilities were $72.0,71.8$ and $76.0 \% \quad(\mathrm{P}<0.01)$. The FU-value of the DPM ration was lower $(\mathrm{P}<0.01)$ than the SBM and UREA rations. The palatability of the concentrate including DPM was depressed $(\mathrm{P}<0.05)$. The differences in milk yield and milk constituents between groups were not statistically significant. Feed utilisation was equal in Expt. $10.37 \mathrm{FU} / \mathrm{kg}$ FCM but in Expt. 2 value of 0.39 for the DPM group was lower than 0.45 for the SBM or 0.43 for the UREA group $(\mathrm{P}<0.05)$.

The values obtained in hematological and blood chemical analyses were within normal ranges. The blood metabolic parameters indicate that DPM can be used as feed for dairy cows without any detrimental effect on health.

The rumen fermentation was investigated with rumen fistulated cows in two experiments. With a constant feeding level and the DPM inclusion adjusted to $0,10,20$ and $40 \%$ of concentrate mixture, the rumen fluid ammonia- $\mathrm{N}$ increased with the increasing amount of DPM in the diet $(\mathrm{P}<0.05)$. The $\mathrm{NH}_{3}-\mathrm{N}$ concentration was still lower $(\mathrm{P}<0.05)$ in the isonitrogenous SBM diet. Furthermore, with increasing DPM inclusion the molar percentage of acetic acid of the total volatile fatty acids increased $(\mathrm{P}<0.05)$, the percentages of propionic acid and butyric acid decreased. The total volume of microbial mass was $10-20 \%$ higher with the SBM diet than the various DPM diets.
\end{abstract}

\title{
1. Introduction
}

The problem of poultry manure disposal has become acute with the intensification of production into efficient and highly mechanized systems. Traditionally the manure has been recycled as fertilizer, but the large quantities generated by the new systems often exceed the capacity of the nearby cropland to accept. The increased public consciousness of environmental 
pollution occuring at the same time has compelled a search for new and efficient disposal methods.

The feeding of dried poultry manure to livestock has recently become economically feasible as the costs of conventional protein supplements for livestock diets have increased. Poultry manure contains a relatively high concentration of crude protein and is rich in minerals. Nutrients from poultry manure have been shown to be efficiently used for the productive functions of ruminant animals.

The possibility of disease transmission and health hazards to the animals fed the wastes or the humans eating products from those animals is a problem requiring clarification.

The chief objective of the experiments performed was to evaluate the feeding value and utility of dried poultry manure as a protein supplement in a concentrate rich diet for high producing dairy cows in the early stages of lactation. The comparative sources of protein were soybean meal and urea. Furthermore, the experiments were conducted to study the digestibility of the poultry manure and the effect on the blood metabolic profile with a view to clarifying the utilisation of the nutrients in poultry manure and the possible health hazards due to manure feeding. The utilisation of nitrogen and the rumen fermentation was investigated with rumen fistulated cows.

The present study is the continuation of investigations conducted and published earlier on waste utilisation; chemical composition and digestibility of poultry manure (NÄsI 1975, SALO et al. 1975, NÄsı 1976), utilisation of DPM as a protein source for beef cattle (NÄsI 1976), fermentation of poultry manure for poultry diets (VUORI and NäsI 1977), and dehydrated mink manure as a protein source for growing pigs and its effect on blood profile of pigs (NÄsI et al. $1978 \mathrm{a}, \mathrm{b})$.

\section{Review of the literature}

\section{1. Production, disposal and utilisation of poultry manure}

\subsubsection{Production of poultry manure}

Statistics on the amount of manure produced by poultry under various conditions have been collected by several workers. According to the literature a laying hen of Leghorn type excretes 99-136 $\mathrm{g}$ of faeces per day (НАsнimoto 1974, Jönsson 1976), or 60-70 kg manure per year. YoshoK and BEAR (1943) have reported that 1000 hens produce 72 tonnes of manure in a year and that the weight of manure voided is about twice that of the feed consumed. These figures agree closely with the data of WARDEN (1963), 80 tonnes, and RUHLAND (1968), 60 tonnes annually. In Finland the total number of poultry in 1978 was 9.4 million omit and the production of poultry manure based on the figures above is approximately 137 million $\mathrm{kg}$ annually.

Laying hens are currently managed in caged, Pennsylvania and deep litter poultry houses. In broiler production the litter method is most common 
and the caged method is being further developed. Caged layer manure is pure excreta, in which litter seldom is mixed. In its dried form this is henceforth referred to as dried poultry manure (DPM). Deep litter consiting of sawdust, straw and peat as well as excreta is designated poultry litter (PL), and manure from broilers is designated broiler litter (BL).

In Finland the intensification of farming is regulated by law (ANON. 1975) and generally the units are small compared with those of Great Britain, Central Europe and America. With increasing public awareness of environmental pollution and new pressures and restrictions on farming, the manure disposal problem can expected to worsen.

\subsubsection{Disposal and utilisation of poultry manure}

Manure in large quantities is an unavoidable product of intensified poultry production. Traditionally it has been used as fertilizer, but economic considerations as well as land shortage in some areas inhibit its return to the soil. Since poultry manure contains many more plant nutrients than other manures (STEINECK 1974, WILKINSON 1979), an area of 7.5 hectares is required to spread the waste produced by 1000 laying hens (Jönsson 1976). The use of excessive amounts of poultry manure as fertilizer can cause nitrate accumulation in soil (Howes 1968). Handling and scattering the wet manure is costly and technical problems exist as well. Fly and odour problems arise where there are large accumulations of poultry manure.

Several types of waste processing systems are currently available. In digestive systems, bacteria, yeast (SINGH and Anthony 1968, JACKson et al. 1970, Vuori and Näsi 1977, Calvert 1979), algae (Kiefer 1971, Calvert 1974 ) or chemicals are used to treat the manure in oxidation ditches or aerobic lagoons or to convert it to fuel for methane generators (Essig 1975). Mechanical drying systems convert the waste to a product suitable for either feed or fertilizer (ARNDT et al. 1979). The standard types are the rotating drum dryer, the conveyor dryer system, the vibration or shaker dryer and the spray system for materials high in moisture content. Other waste processing systems involve the ensiling of the waste product either separatively or in combination with forage to obtain a forage waste fermented product suitable for cattle (HARMON et al. $1975 \mathrm{a}, \mathrm{b}, \mathrm{CASWELL}$ et al. 1978). With the increasing cost of fossil fuel the mechanical drying of wastes is becoming almost prohibitively expensive. Under certain management conditions, wet poultry excreta can be fed to ruminants without drying but the product must be stabilized to minimize nitrogen losses and its odour controlled by chemical treatment, eg. organic acids or formaldehyde (McNiven et al. 1976, Evans et al. 1978 b, Koenig et al. 1978, Sмrтн et al. $1978 \mathrm{a}$ ).

The idea of refeeding poultry wastes to other animals as one way of meeting the waste problem is relatively new. Many research reports indicate that poultry excreta can be effectively utilised by ruminants as a source of nitrogen and minerals (eg. El-SABban et al. 1970, Tinnimit et al. 1972, Fontenot and Webb 1974, Cullison et al. 1976, Smith and Calvert 1976, Smith and WHEELER 1979). 


\section{2. Composition and nutritional value of poultry manure}

\subsubsection{Composition and factors affecting the composition of poultry manure}

Poultry excreta is composed of undigested food residues, mainly structural carbohydrates and unabsorbed food constituents, together with metabolic faecal and urinary components. It includes also cells and micro-organisms from the alimentary tract. Poultry manure is variable in composition, even on a dry matter (DM) basis. The main causes of variability are probably variation in the composition of the feed, variable feed spillage into the manure, differences in the stage of lay of hens, and feather shedding (PERKINS and PARKER 1971, Young and Nesheim 1972, Vogt 1973, Blair 1974, Evans et al. 1978 a).

The age of the manure at the time of drying is extremely critical to its feed value. Manure should be held no longer than three days after voiding and is best dried on a daily basis, as the crude protein content decreases with the age of the manure. The crude protein content may vary from as high as $33 \%$ in dry matter (DM) when dried the day voided, to as low as $11 \%$ if allowed to stand and ferment, so that the nitrogen losses may increase to up to $60 \%$ of total nitrogen (SURBRook et al. 1971, FLEGAL et al. 1972, Couch 1972, KuBEnA et al. 1973).

The efficiency of dehydration influences the composition of DPM. In particular, the temperature and duration of drying process affect the content of nitrogen compounds. Manoukas et al. (1964) reported losses of gross energy and nitrogen ranging from 1.2 to $2.2 \%$ and 7.1 to $15.2 \%$ respectively, when layer exreta were dried in a convection oven at $65^{\circ} \mathrm{C}$ for 24 hours. The mean losses of nitrogen due to drying in a forced-air oven increased from 4 to $10 \%$ and the energy decreased from 6 to $3 \%$ as the temperature increased from 60 to $120^{\circ} \mathrm{C}$ (Wittenberg and Chudy 1967, Shannon and Brown 1969). SHEPPARD et al. (1971) observed an inverse relationship between the temperature of treatment and resulting crude protein content in DPM. Acidifying broiler litter to $\mathrm{pH} 6$ prior to drying reduced the nitrogen loss (FonTENoT et al. $1971 \mathrm{~b}$ ). Certain organic acids and formaldehyde treatments have also been successful in preventing nitrogen losses (Evans et al. 1978 b, KoENIG et al. 1978, Sмітн et al. 1978 a).

The digestibility of crude protein is reportedly decreased with heating, too (BRUgman et al. 1967).

\section{2. 2. Chemical composition of poultry manure}

The average compositions of dried poultry manure, poultry litter and broiler litter obtained from different sources are presented in Appendix 1 . Poultry manure in fresh state contains $13-26 \%$ dry matter; after drying the dry matter percentage increases to $82-96$ (Vogt 1973, LoEHR 1974, NÄsI 1976). Poultry litter contains 52-75\% dry matter (Yoshoк and BEAR 1943, PARKER et al. 1959). The carbon content of DPM is $34-35 \%$ in DM. The available carbohydrates are digested fully by fowl. A great proportion of the undigested carbohydrates is made up of grain hulls, consisting of pentosanes cellulose and lignin (Vogt 1973). The ash content of DPM is high, $19-40 \%$. Poultry feeds are supplemented with different minerals and any unabsorbed 
minerals go into the manure. Poultry manure is rich in minerals, especially calcium and phosphorus (Appendix 1).

\section{2.3. Nitrogen components of poultry manure}

Poultry manure has a high nitrogen content - between 3 and $8 \%$ of DM - and the crude protein content usually makes up over $30 \% \quad(20-45 \%)$ (BHATTACHARYA and TAYLOR 1975). The percent of nitrogen in the feed recovered in the manure of laying hens is $71-86$ (YosHoK and BEAR 1943, Dugan et al. 1970, Hashimoto 1974) and the faecal protein content varies between 10.1 and $14.8 \%$ on a dry matter basis (SHANNON et al. 1973). In broiler litter $45 \%$ or more of the total nitrogen is in the from of true protein (BнAтTAChARyA and Fontenot 1966, Fontenot et al. 1966). Of the nitrogoen in caged layer manure $24-41 \%$ is in the form of amino acids (Lie вHolz 1969, Böнме 1972, TERPSTra and DEHART 1974). About $18 \%$ of the faecal nitrogen is bound in free amino acids and therefore not presipitable (TERPSTRA and DEHART 1974). The amino acid composition of DPM, PL and BL is presented in Appendix 1. The composition and quantity of amino acids present in poultry manure are comparable to cereals (BöHme 1972, Tüller 1972). Their availability is not known.

Uric acid and urates are the most abundant nitrogen compounds in urine of fowl, while ammonia and urea are present in much smaller amounts. The uric acid content of DPM varies, usually between 2.3 and $11.4 \%$ on a dry matter basis (Shannon et al. 1973, McNab et al. 1974, Terpstra and deHart 1974). There is general agreement that uric acid nitrogen constitutes 60 to $82 \%$ of the total urinary nitrogen. Ammonia nitrogen $\left(\mathrm{NH}_{3}-\mathrm{N}\right)$ has been reported to comprise 6 to $23 \%$ and urea-N 2 to $10 \%$ of the total urinary nitrogen (O'Dell et al. 1960, Sykes 1971, McNabB and McNabB 1975).

\section{2. 4. Digestibility of poultry manure}

Poultry waste has substantial nutritional value, especially for cattle and sheep wich can digest fibre and utilise nonprotein nitrogen (NPN). The digestibility of the dry matter in DPM has been calculated to be about 60 percent for ruminants. The amount of DPM and the composition of the rations as well as the composition of DPM itself varies in different digestibility trials, however, and the exact comparison of literature results is difficult.

The apparent digestibility of supplemental DPM is usually a little lower than that of the basic ration. DPM was found to be $25 \%$ units less digestible in DM and $15 \%$ units less in organic matter than a concentrate carrier mix used as the feed for DPM. The amount of digestible DM in DPM is about the same as in low quality alfalfa hay but digestible organic matter is about $\mathbf{1 . 2 5}$ times greater (Tinnimit et al. 1972).

The five diets of Lowmann and KNIGHT (1970) fed to sheep ranged from 0 to $100 \%$ DPM in steps of $25 \%$, the remainder of the ration being barley. The dry matter digestibility of the diets gradually fell from that of $100 \%$ barley to that of $100 \%$ DPM in a highly significant straight line. The groups of sheep fed $100 \%$ DPM digested $57 \%$ of the DM. Thомas (1970) found the 
digestibility of DPM to be $58 \%$ when $32 \%$ of a basic ration was replaced with DPM. PARIGI-Bini (1969) replaced $32 \%$ of a barley-soy diet with DPM and found the DM digestibility of the diet to be $80.5 \%$ which is considerably higher than the previously cited figures. The extrapolation to $100 \%$ gives an average dry matter digestibility of $65 \%$. The digestibility of plant cell walls in DPM as determined by a in vivo method was found to be 60 to $76 \%$ (Smith 1974).

The crude protein of DPM has been reported to be about $53 \%$ digestible when fed as a main source of protein for sheep (Tinnimit et al. 1972). However, other reports have assigned a higher protein digestibility of $73-77 \%$ (Lowman and Knight 1970, Bull and Reid 1971, Salo et al. 1975). Smith and Calvert (1972) reported no difference in crude protein digestibility in diets where DPM was substituted for 0,50 or $100 \%$ of the soybean meal in sheep ration.

\subsubsection{Energy value of poultry manure}

The energy content of DPM is highly variable due to its variable composition and digestibility. The overall energy value is low owing to the high ash and NPN content and low amount of fat and available carbohydrates.

The gross energy of DPM varies from 12.5 to $14.6 \mathrm{MJ} / \mathrm{kg}$ DM (Low MAN and Knight 1970, Bull and Reid 1971, Polin et al. 1971, Tüller 1972, Vogt 1973). The digestible energy content is $8.4 \mathrm{MJ} / \mathrm{kg}$ DM for sheep and cattle making it approximately equivalent to low quality hay (Lowman and KNIGHT 1970, Bull and REID 1971, SALO et al. 1975, NÄSI 1976). Metabolizable energy (ME) values have ranged from 4.6 to $6.7 \mathrm{MJ} / \mathrm{kg}$ DM (PRYOR and Connor 1964, Yoshida and Hoshin 1968, Oliphant 1974). The corresponding ME values for poultry are lower, 3.2-5.6 MJ/kg DM (Hodgetts et al. 1971, Nesheim 1972, Polin et al. 1972, Shannon et al. 1973, Harnisch 1974). With ruminants the net energy value has been reported to be $0.35-0.52$ starch units per $\mathrm{kg}$ DM (PARigi-Bini 1969, Böhme 1972, Blair and Knight $1973 \mathrm{a}$, b) and the feed unit (FU) value 0.42 (Poppe and Grugel 1971, Kristensen et al. 1976).

The digestible energy value of broiler litter for sheep has been found to be 10.0 MJ/kg DM and the ME value $9.2 \mathrm{MJ} / \mathrm{kg}$ DM (Bhattacharya and Fontenot 1966). The digestible energy of wood shawings containing poultry litter was found to be about $8.4 \mathrm{MJ} / \mathrm{kg}$ with cattle (BRUGMan et al. 1964).

\section{3. Utilisation of poultry manure as feed for animals}

\subsubsection{Poultry manure and uric acid as a nitrogen source for ruminants}

Poultry manure has a high crude protein content and is a potential source of nitrogen for ruminants. Over $60 \%$ of the nitrogen in DPM is NPN, mainly uric acid. Uric acid is utilised by rumen micro-organisms in vitro (BELAsco 1954, Jurtshuk et al. 1958, Koenig et al. 1978). Oltjen et al. $(1968,1972)$ found in vivo that uric acid is degraded by rumen micro-organisms more slowly than urea suggesting a more favorable ruminal ammonia pattern for

afficient N utilisation. SLYTER et al. (1968) reported higher concentrations of cellulolytic bacteria in steers receiving supplemental $\mathrm{N}$ from uric acid than 
those receiving urea or urea phosphate. Steers gained weight more rapidly and efficiently on diets containing $40 \%$ of their dietary nitrogen in the form of uric acid or sodium urate than on diets containing similar percentages of $\mathrm{N}$ as urea or biuret (Oltjen and Dinius 1976).

OLtJEn et al. (1968) found that when uric acid was fed as the sole source of nitrogen in a purified diet, the apparent digestibility of the uric acid was $68 \%$ and the retention of the ingested nitrogen $23 \%$. In that study steers consumed $140 \mathrm{~g}$ of uric acid and excreetad only $0.6 \mathrm{~g}$ in their urine daily. The results indicate that uric acid is readily degraded in the digestive tract. OLTJEN and Dinius (1976) noted similar digestibilities when uric acid supplied $50 \%$ of the dietary nitrogen, $34 \%$ of the ingested nitrogen being retained.

Tinnimit et al. (1972) evaluated DPM nitrogen by replacing $45 \%$ of the soy protein nitrogen in a sheep ration fed in restricted or ad libitum amounts and observed a significant $10 \%$ depression in protein digstibility of the DPM ration. However, nitrogen retention and percent of absorbed nitrogen retained with the DPM ration were equal to the control in the restricted study, and $10 \%$ higher than the control in the ad libitum study. When DPM provided $88 \%$ of the ration's nitrogen, both total nitrogen retained and percentage of absorbed nitrogen reained dropped a significant $30 \%$.

\section{3. 2. DPM as a protein supplement for lactating cows}

Low levels of poultry manure have been used successfully in the diets of dairy cattle (Thomas and ZINDEL 1971) and DPM has been substituted as a protein supplement in the rations of high producing dairy cows totally or in high proportions with satisfactory results (BULL and REID 1971, THOMAs et al. 1972, Smith and Fries 1973, Smith and Wheeler 1979). Some reports indicate that an individual animal will not consume enough of the manure and an adaptation period is necessary (BULL and REID 1971, Thomas et al. 1972, Smith et al. 1976). However, Claesson and Ahlström (1974) reported that most animals will consume DPM 5-6 kg/day without difficulties.

In Sweden trials have been performed in which the cows were fed DPM during the whole lactation period. Milk production was over $5000 \mathrm{~kg} / \mathrm{year}$ the concentrate mixture included $40 \%$ of DPM. The substitution value of the poultry manure was $116 \%$ of cereal and $60 \%$ of the soybean meal (CLAEsson and Ahlström 1974). Тномаs et al. (1972) showed equal production and feed utilisation in feeding experiments when DPM was compared with soybean meal or urea but significantly more when the cows were receiving inadequate protein. In a 90-day trial SMITH and FrIES (1973) found that cows fed a poultry excreta concentrate consumed less maize silage and concentrate dry matter, gained less weight and produced less milk than cows fed a control concentrate. Lower milk productions by cows on DPM diets have also been reported by KNEALE and Garstang (1975), Kristensen et al. (1976), Silva et al. (1976) and Smith et al. (1976). The lower milk production was due primarily to lower consumption of feed and the lower energy value of rations containing DPM (Appendix 2).

In some trials the ash content of DPM has been very high: $30-40 \%$ on a dry matter basis (KRISTEnsen et al. 1976, Silva et al. 1976), which lowered 
the energy value of the ration. Supplementing the DPM concentrate mixture with animal fat was found to have favourable results (KRISTENSEN et al. 1976).

The limiting factor in the use of dried poultry waste in dairy rations appears to be the impaired energy value of the feed when this material is included, not the utilisation of NPN. Even when $20 \%$ of the ration is in the form of dried waste, half of the total crude protein is supplied by the cereal. Hence, poultry waste should not be detrimental to the production when supplying the equivalent of $15-20 \%$ of the dietary protein of ruminants unless energy is deficient. The complete replacement of soybean meal by DPM tended to reduce milk production of cows but at the same time reduced the cost of the production (KNEALE and Garstang 1975).

In supplementing a concentrate mixture with DPM, most of the mineral requirements are satisfied at the same time, owing to the rich mineral content of DPM.

\subsubsection{Feeding poultry waste in beef and sheep production}

Beef cattle and sheep are traditionally not given the same high quality proteins included in dairy cattle rations. A cheap, low quality protein such as poultry waste would be expected to have an even greater potential value in beef cattle and sheep fattening diets. Rations containing cheap cereals and cheap DPM for cattle are an attractive commercial proposition and are already manufactured and marketed by animal feed compounders in Britain (BLAIR and Knight 1973 b, Blair 1974, Oliphant 1973, 1974).

Many research reports indicate the satisfactory use of dried poultry manure and poultry litter in beef production. The average daily gain and feed conversion efficiency has been comparable to that obtained with soybean or sunflower meal in fattening rations (Noland et al. 1955, Southwell et al. 1958, Fontenot et al. 1963, 1966, BRUgman et al. 1964, Rusnak et al. 1966, Long et al. 1969). Different litter materials have not been found to have any effect on the gains of steers at 25 or $40 \%$ supplemental levels of PL (DRAKE et al. 1965).

Large proportions of DPM as protein supplement have sometimes had significant negative effects on daily gains of beef steers. In some cases the depression of the gain was probably due to the inadequate consumption of DPM (Bucholtz et al. 1971, PopPe and Grugel 1971). In a two-year trial OLIPHANT (1974) found that average daily gain did not change as a result of incorporating $\mathbf{1 7 . 5} \%$ DPM as a complete nitrogen replacement for soybean meal and fish meal in a barley ration. The dry matter intake, average daily gain, feed efficiency and nutrient utilisation were not found to be different between cattle fed corn meal containing $12.8 \%$ cotton sead meal or $20.5 \%$ DPM (Smith 1974). Moreover Cullison et al. (1976) observed that the performance of steers receiving broiler faeces as 0,50 and $100 \%$ of their supplemental protein in place of soybean, was similar when daily gain, feed intake and feed efficiency were considered, however. In a Danish study Urimix $(90 \%$ DPM, $5 \%$ animal fat and $5 \%$ molasses) was included in the rations of beef cattle and because of the low energy content in the manure the daily gain decreased and the intake of dry matter increased with the increasing amount 
in the ration. Daily live weight gain and carcass gain decreased $40 \mathrm{~g}$ and $30 \mathrm{~g}$ respectively for every $10 \%$ of Urimix included in the ration (REFSSGAARDANDERSEn et al. 1976). Using a DPM supplement NÄSI (1975) found a $40 \mathrm{~g}$ decrease in daily gain compared with a soybean meal supplement and in feed conversion efficiency of $0.12 \mathrm{FU} / \mathrm{kg}$ live weight gain.

Likewise DPM has been fed as a protein supplement to growing sheep, with mixed results. Thomas et al. (1972) observed that sheep fed $19 \%$ crude protein rations containing 61 or $90 \%$ total protein from DPM gained significantly less than sheep fed a control soybean meal ration: 160 and $210 \mathrm{~g} / \mathrm{d}$, respectively. On the other hand, Sмiтн et al. (1973) reported gains of $180-190$ $\mathrm{g} / \mathrm{d}$, which were not significantly different, for sheep fed pelleted rations in which 0 to $40 \%$ of the crude protein was provided by DPM. The acceptability of DPM has been found to be good when fed to growing sheep as 20 to $80 \%$ of the mixed ration, DPM furnishing 40 to $90 \%$ of the ration nitrogen (Tinnimit et al 1972). And broiler faeces were used successfully for lambs in a wheat ration (McInnes et al. 1968). Milking ewes failed to show any changes in quantity or quality of milk production when the concentrate mixture fed included $50 \%$ DPM (Zorita et al. 1968). Fontenot et al. (1972) concluded long-term studies on gestating ewes fed rations containing 0,25 and $\mathbf{5 0} \%$ broiler litter. Their results indicated that all three rations produced equal body weight in the ewes until the end of lactation.

\section{3. 4. Feeding recycled DPM to non-ruminants}

The feed value of DPM for poultry and pigs is lower than that for ruminants because they are unable to utilise the uric acid and crude fibre fractions. For this class of livestock DPM is broadly equivalent, in terms of protein and amino acids, to a cereal such as barley (BLAIR and KNIGHT 1973 a).

Growth trials with chicks have indicated that the true protein in DPM is highly available to the bird (LEE and BLAIR 1972, 1973, McNAB et al. 1972, 1974, HARNISCH 1974). DPM is low in available carbohydrates and fat so that the energy value is low, between 3.2 and 5.6 MJ ME $/ \mathrm{kg} \mathrm{DM}$, about one third of the value for barley. DPM is a very useful source of readily available calcium and phosphorus (PARKer et al. 1959, McNAB et al. 1974).

Dried poultry excreta has been successfully included at levels of up to $20 \%$ in diets for layers and broilers (FLEGAL and ZINDEL 1970, BIELY et al. 1972, Lee and Blair 1973, Sloan and Harms 1973, Vogt 1973, Biely and Stapleton 1976). Where the birds require high density diets, for example broilers, fat must be used to maintain an adequate dietray energy and thereby maintain satisfactory growth rates. In practice DPM is normally suited to low density diets, in which case the daily feed allowance should be increased.

The proportion of manure that can actually be used by birds is quite low owing to the low digestibility of excreta DM: 10-24.4\% (Nesheim 1972, ShANNON et al. 1973, McNAB et al. 1974). Recycling poultry manure through poultry could be expected to achieve a reduction of about $20-25 \%$, and Young and Nesherm (1972) have achieved a reduction of about $16 \%$ with a continuous recycling system in a battery layer unit. 
While pigs are able to tolerate large amounts of DPM in the diet, the nutritive value is low. Perez-Aleman et al. (1971) found that DPM acted as a diluent. GERI (1968) fed pigs 7-10\% DPM and found that generally the growth rate was similar on the manure diet and on the control diet, although feed conversion efficiency was poorer with manure in the diet. No digestibility data are presented but in view of the effects of manure inclusion on feed conversion efficiency it is reasonable to conclude that the pig utilises manure to the same extent as do poultry. From the data reported it would appear that no more than $5 \%$ DPM can be included in swine rations without influencing growth rate, feed conversin efficiency and carcass quality.

\section{4. Health aspects of recycling poultry manure}

Recycling of animal wastes by feeding opens the way for the transfer pathogenic bacteria, fungi, and residues of pesticides, feed additives, hormones, heavy metals and medicinal drugs. For this reason the commercial production of DPM for feed is prohibited in many European countrieas and in theUnited States (McCaskey and Anthony 1979, Taylor and Geyer 1979). Detrimental effects have occasionally been noted in animals, for example, in sheep fed broiler litter or DPM containing high level of copper (LowMAN and KNIGHT 1970, Fontenot et al. 1971 a, WebB et al. 1973, Suttle et al. 1978); and abortion in cattle has been linked to the feeding of poultry litter (GRIEL et al. 1969). However, there is no indication yet of harmful effects in humans consuming meat, milk and eggs from animals fed this waste material (SYRETT 1977).

Most of the contaminating substances have on some occasions been detected in poultry manure (BRUgman et al. 1964, Fontenot et al. 1971 a, Messer et al. 1971, WEвB and Fontenot 1975). But in general no harmful levels of those substances tested have been found in edible tissues of animals fed DPM (Brugman et al. 1968, Griel et al. 1969, Thomas et al. 1972, VArghese and FLEGAL 1972).

It would seem that the greatest risk is in the transmission of pathogens and parasites, both between animals and to man (Shannon et al. 1973). Most of the microbes present in poultry manure belong to the normal flora of the alimentary tract of fowl or their environment. The population of microbes is relatively constant at $10^{9}-10^{10} / \mathrm{g}$ excreta (HALBROoK et al. 1961, SCHEFFERLE 1965). The count is not dependent on environmental factors, pH, age, temperature or the humidity of the manure. Bacterial types and densities have been studied in poultry manure and litter (AlEXANDER et al. 1968, KRAFT et al. 1969, Zindel 1970, Lovett et al. 1971, Messer et al. 1971) and a variety of different pathogenic bacteria and fungi detected. Kraft et al. (1969) performed a quantitative test for Salomonella in excreta samples from 91 poultry houses and found that $29 \%$ were positive. Lovert et al. (1971), however, did not detect any Salmonella organisms in samples of poultry litter. Pathogenic bacteria were isolated from 31 out of 44 different field samples of DPM, of which 26 were being used for feeding livestock (ALEXANDER et al. 1968). The risk of transmission of bacteria can be diminished if the manure is recycled on the same farm as it is produced (Alexander et al. 1968, LovetT et al. 1971). 
Fortunately the majority of the disease organisms present in the unprocessed manure are destroyed by heat treatment. Accordingly it is essentilal that the manure be adequately heated throughout the whole mass when being dried, and that the processed manure does not become recotaminated by contact with unprocessed manure or with contaminated equipment. The pathogenic species Salmonella sp. and Arizona sp. are not resistant to heating treatment Messer et al. (1971) but Escherichia coli cannot be considered as an indicator of the heating treatment (PLATZ 1975). The application of dry heat at $150^{\circ} \mathrm{C}$ for $4 \mathrm{~h}$ or longer apperars to sterilize broiler litter according to FONTENOT et al. (1971 b).

Recent research has indicated that ensiling litter with added water (GREGER et al. 1973), corn forage (HARMon et al. $1975 \mathrm{a}, \mathrm{b}$ ) or high moisture corn (CASWELL et al. 1978) results in reduction or complete elimination of pathogens. In some studies satisfactory results have been obtained by adding organic acids or formaldehyde as preservant and to destroy microbes (Evans et al. 1978 b, Sмiтн et al. 1978 a, b, Koenig et al. 1978).

Clearly potential disease problems do exist. While sterilization of manure, though feasible, is not a viable propostition, processes used for recycling can at least reduce the numbers of relevant pathogens to harmless proportions. Tests need to be developed for microbial and fungal toxins, pathogenic organisms and parasites in the finished product. Also needed is a detailed description of the manufacturing process, in which all materials added are specified.

In the light of present knowledge, however, dried poultry manure that has been properly processed appears to present no serious health dangers when fed to ruminants. In England, for example, DPM has been used commercially as a feedstuff for several years, and no cases of failure due either to contamination with microorganisms or feed additives have been reported (BLAIR 1975).

\section{Materials and methods}

\section{1. Feeding experiments}

\section{1. 1. Experimental desing}

Two consecutive feeding experiments were carried out, in which dried poultry manure (DPM), soybean meal (SBM) and urea were used as protein supplements in a concentrate-rich diet for high producing dairy cows in the stage of early lactation. Both experiments involved 18 dairy cows randomly divided into three groups equivalent in regard to milk yield during the standardization period, days post partum, number of lactations, live weight and breed. Sixteen of the cows were Ayrshires and two were Friesians. One cow with severe mastitis had to be withdrawn from the soybean meal group in Expt. 2. The groups are referred to as DPM1, SBM1 and UREA1 in Experiment 1 and DPM2, SBM2 and UREA2 in Experiment 2 according to the protein supplement supplied. 
Mean weight, number of calvings, day from calving at the beginning of the experimental period and milk yield in the standardization period for each group were as follows:

\begin{tabular}{|c|c|c|c|c|c|c|}
\hline Experiment & Group & $\begin{array}{c}\text { Number of } \\
\text { calvings }\end{array}$ & $\begin{array}{l}\text { Days from } \\
\text { calving }\end{array}$ & $\begin{array}{l}\text { Milk yield } \\
\text { kg }\end{array}$ & $\begin{array}{c}4 \% \mathrm{FCM} \\
\mathrm{kg}\end{array}$ & $\begin{array}{l}\text { Live weight } \\
\text { kg }\end{array}$ \\
\hline \multirow[t]{3}{*}{$\underline{1}$} & DPM1 & 1.33 & 30.3 & 18.3 & 20.6 & 532 \\
\hline & SBM1 & 2.00 & 28.0 & 18.4 & 19.5 & 502 \\
\hline & UREA1 & 1.83 & 26.8 & 19.9 & 19.7 & 483 \\
\hline \multirow[t]{3}{*}{$\underline{2}$} & DPM2 & 2.17 & 33.3 & 20.5 & 22.4 & 534 \\
\hline & SBM2 & 2.20 & 38.4 & 20.3 & 21.8 & 547 \\
\hline & UREA2 & 2.30 & 34.5 & 20.3 & 21.4 & 516 \\
\hline
\end{tabular}

After a two-week standardization period, in which all the animals received a feeding regimen consisting of $2 \mathrm{~kg}$ hay, grass silage ad libitum and a grain concentrate mixture according to milk production, the cows were gradually accustomed to the experimental feeds over a period of one week. The experimental periods lasted 13 and 15 weeks in Expts. 1 and 2 respectively.

\subsubsection{Experimental feeds and feeding}

The cows were kept in separate stalls and fed individually according to the feeding scheme twice daily. Refusals were collected daily after the morning feeding. Cows were weighed on two consecutive days at the beginning and end of the experimental period and every second week during the trial after the morning feeding.

All cows were fed $6.0 \mathrm{~kg}$ and $7.0 \mathrm{~kg}$ of hay in Expts. 1 and 2 respectively, and a concentrate mixture according to milk production. The rations were adjusted every week according to requirements on the basis of the previous week's fat corrected milk yield and live weight. The calculations of requirements for energy $(\mathrm{FU}=0.7 \mathrm{~kg}$ starch) and digestible crude protein were based on the current Finnish standard: for maintenance $4 \mathrm{FU}$ and $300 \mathrm{~g}$ DCP per $500 \mathrm{~kg}$ live weight plus $0.4 \mathrm{FU}$ and $60 \mathrm{~g}$ DCP per $4 \%$ fat corrected milk (FCM).

The groups were fed a grain concentrate mixture supplemented with one of the protein sources (DPM) $20 \%$ dried poultry manure

(SBM) $10 \%$ soybean meal

(UREA) $\quad 1.5 \%$ urea

The composition of the concentrate mixtures and calculated energy and protein values are shown in Table 1 .

The poultry manure was collected from a caged layer house and rotary drum dried and ground. The cows were fed $20 \mathrm{~g}$ sodium chloride a day plus for DPM1 and DPM2 groups $5 \mathrm{~g}$ and for SBM1, SBM2, UREA1 and UREA2 groups $10 \mathrm{~g} / \mathrm{kg}$ milk produced of a commercial mineral supplement $(\mathrm{g} / \mathrm{kg}, \mathrm{Ca}$ 83.8, P 50.4, Mg 36.8, Na 100.1, K 0.8, Fe 4.69, Cu 0.33, Zn 1.62).

\section{1.3. Sampling and analyses}

The milk yield of each cows was recorded at every milking and samples of the day's milk were taken twice a week for analysis. Milk fat, protein and 
Table 1. Composition of concentrate mixtures and calculated energy and protein values.

\begin{tabular}{|c|c|c|c|}
\hline Supplements & $\begin{array}{c}\text { DPM } \\
\% \\
\end{array}$ & $\begin{array}{c}\text { SBM } \\
\% \\
\end{array}$ & $\begin{array}{c}\text { UREA } \\
\%\end{array}$ \\
\hline 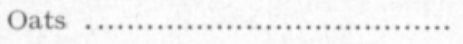 & 35 & 40 & 44 \\
\hline 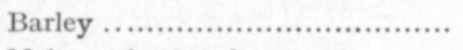 & 35 & 40 & 44 \\
\hline Molasses-beet pulp ................... & 10 & 10 & 10 \\
\hline Dried poultry manure $. . . \ldots \ldots \ldots . .$. & 20 & - & - \\
\hline Soybean meal ......................... & - & 10 & - \\
\hline 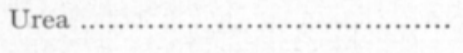 & - & - & 1.5 \\
\hline Experiment $\underline{1}$ & DPM1 & SBM1 & UREA1 \\
\hline 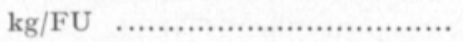 & 1.16 & 1.01 & 1.02 \\
\hline 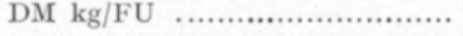 & 1.02 & 0.88 & 0.89 \\
\hline DCP $\%$ in DM & 13.5 & 14.5 & 14.0 \\
\hline DCP g/kg ........................... & 121 & 127 & 123 \\
\hline 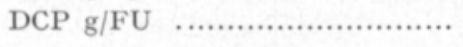 & 138 & 128 & 126 \\
\hline Experiment $\underline{2}$ & DPM2 & SBM2 & UREA2 \\
\hline 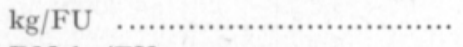 & 1.21 & 1.04 & 1.06 \\
\hline DM kg/FU ......................... & 1.07 & 0.93 & 0.94 \\
\hline DCP $\%$ in DM $\ldots \ldots \ldots \ldots \ldots \ldots \ldots \ldots \ldots \ldots$ & 11.0 & 13.8 & 13.6 \\
\hline 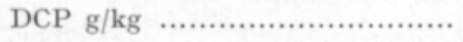 & 100 & 123 & 120 \\
\hline 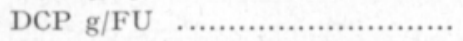 & 121 & 128 & 127 \\
\hline
\end{tabular}

lactose contents of the samples were analysed with an infrared analyser (IRMA) in the laboratory of Valio Company. Total solids were determined by oven heating at $103^{\circ} \mathrm{C}$ and ashed at $600^{\circ} \mathrm{C}$ overnight.

The components of the concentrate mixtures were sampled before mixing every week and pooled into one sample for two weeks. Samples of hay were taken every day. The chemical composition of feeds was determined from the pooled samples. Dry matter contents were determined by oven heating at $103^{\circ} \mathrm{C}$ and samples for feed analysis were dried in a vacuum oven at $50^{\circ} \mathrm{C}$. The feed analyses were made on the dried samples by standard methods ( $\mathrm{PA}_{\mathrm{A}}$ LOHEIMo 1969) and sugar analyses were made according to Somogyi (1945) as modified by SALO (1965). Uric acid was determined as suggested by PrAETORIUS and POULSEN (1953) before and after oxidation by uricase at $293 \mathrm{~nm}$. Mineral composition of the feeds was determined by atomic absorption spectrophotometer (Varian Techtron AA 1000) and phosphorus by the method of TAUSSKY and SHORR (1953).

\section{2. Digestibility trial}

During Experiment 1 all cows were used to obtain digestibility values for the experimental rations. Ten grams of chromic oxide paper $\left(37.48 \% \mathrm{Cr}_{2} \mathrm{O}_{3}\right)$ was fed directly into the oesophagus twice daily for fourteen days. There was a five-day collection period, during which grab samples of faeces were obtained from the rectum twice daily.

Faeces were dried under vacuum at $50^{\circ} \mathrm{C}$ and subsequently analyzed by standard methods as in the feed analyses. Chromic oxide was determined by the method described by Kimura and Miller (1957). 


\section{3. Blood metabolic profile}

Blood samples were collected by puncturing of Vena jugularis at the start of the feeding trials and at two-week intervals thereafter. Samples were taken two hours post feeding. In Expt. 1119 samples were taken and in Expt. 2, 128. During the metabolism experiment 2 blood samples were collected from the same two cows three times a day $0.5,2.5$ and 5.5 hours after feeding on three days of each period, for a total of 90 samples. The samples for chemical analyses were transferred to heparinized test tubes and those intended for hematological determinations to EDTA tubes. The heparainized tubes were immediately centrifuged and the plasma decanted. Determinations of plasma glucose, urea and protein in plasma were carried out immediately. Plasma was stored deep frozen, and determinations of minerals and trace elements were made at a later date. The following assay methods were used:

Hemoglobin by the cyanomethomoglobin method, hematocrit (PCV) by centrifuging for $5 \mathrm{~min}$ at $1500 \mathrm{rpm}$, plasma glucose by the o-toluidine method (Hultman 1959, modified by Hyvärinen and Nikkilä 1962), plasma urea-N by the Berthold phenolhypochlorite method (Chaney and Marbach 1962), total plasma protein by the biuret method (REINHold 1953) and uric acid by the method described by CARAwaY and HaLd (1963). Inorganic phosphorus was determined by reaction with ammonium molybdate and reduction with ferrous chloride (HENRY et al. 1974). Contents of calcium, magnesium, sodium and potassium were determined by atomic absorption spectrophotometer after dilution of the plasma with lanthanum oxide solution, and iron, copper and zinc were analysed direct with Varian Techtron AA 1000 equipment.

\section{4. Metabolism trials}

Two metabolism experiments were carried out with four cows, two in each trial. The cows had permanent rumen fistulas inserted. In both experiments the effect of different amounts of dried poultry manure as a protein source on rumen fermentation was studied. All experimental periods were of two weeks duration. The cows in Expt. 1 were fed $6 \mathrm{~kg}$ hay and $6 \mathrm{~kg}$ of a concentrate mixture and those in Expt. $2,7 \mathrm{~kg}$ hay and $7 \mathrm{~kg}$ concentrate mixture. All animals received as well 100 grams of mineral mixture and $20 \mathrm{~g}$ of sodium chloride daily. DPM comprised $0,10,20$ or $40 \%$ of the concentrate mixture. The rumen fluid samples were taken 3,5 and 8 hours post feeding in Expt. 1 and 0.5, 2.5 and 5.5 hours post feeding Expt. 2, on three consecutive days in each period. Ninety rumen fluid samples were obtained, 18 for each of the diets, in both experiments. Samples of the rumen content taken through the fistula were collected into a glass jar. $\mathrm{pH}$-measurements were made immediately. The samples were centrifuged for $10 \mathrm{~min}$ at $2000 \mathrm{rpm}$ and ammonia nitrogen $\left(\mathrm{NH}_{3}-\mathrm{N}\right)$ and volatile fatty acids (VFA) determinations were made on the supernatant. $\mathrm{NH}_{3}-\mathrm{N}$ analyses were made calorimetrically by modification of the method of McCullough (1967). The VFA determinations were made by gas chromatography method (Huida 1973). Samples for the determination of rumen microbiota, $5 \mathrm{ml}$ of rumen content, were transferred 
to a glass bottle containing $45 \mathrm{ml}$ of $10 \%$ formalin. The total numbers and identification of the ciliates were established as described by SYRJÄLÄ et al. (1976). The bacterial cells were counted using a counting chamber of dimension $1 \times 1 \mathrm{~mm}$ and $0.2 \mathrm{~mm}$ depth. Three preparations were made of each rumen sample for the counts.

\subsection{Statistical analysis of results}

The results obtained were processed with a UNIVAC 1108 computer using the HYLPS statistical systems (Anon. 1976). The weekly data of feed and nutrient consumption and milk yield were calculated for each cow. Energy requirements for maintenance and production were calculated using Finnish standards, live weight change being taken as requiring $2 \mathrm{FU} / \mathrm{kg}$. Average yields and nutrient consumption data were calculated for cow and tested by one-way variance analysis. Metabolism data from blood and rumen fluid analyses were tested by two-way variance analysis. The differences between treatment means were tested by the Tukey-test (STEEL and Torrie 1960). The effect of time is excluded in the calculation of correlations.

\section{Results and discussion}

\section{1. Feeding experiments}

\subsubsection{Feed composition and consumption}

The average chemical composition, calculated energy and digestible crude protein values of the feeds are given in Table 2. The amino acid composition

Table 2. Composition of feeds and calculated feed values.

\begin{tabular}{|c|c|c|c|c|c|c|c|c|}
\hline \multirow{2}{*}{$\begin{array}{c}\text { Dry } \\
\text { matter } \\
\%\end{array}$} & \multicolumn{4}{|c|}{ In dry matter, $\%$} & \multirow[b]{2}{*}{ Sugars } & \multirow{2}{*}{$\begin{array}{l}\text { Uric } \\
\text { acid }\end{array}$} & \multirow{2}{*}{$\begin{array}{l}\text { FU } \\
/ \mathrm{kg} \\
\mathrm{DM}\end{array}$} & \multirow{2}{*}{$\begin{array}{l}\text { DCP } \\
\mathrm{g} / \mathrm{kg} \\
\mathrm{DM}\end{array}$} \\
\hline & Ash & $\begin{array}{ll}\text { Crude } & \text { Ether } \\
\text { protein } & \text { extract }\end{array}$ & $\begin{array}{l}\text { Crude } \\
\text { fibre }\end{array}$ & NFE & & & & \\
\hline
\end{tabular}

\begin{tabular}{|c|c|c|c|c|c|c|c|c|c|c|}
\hline Hay .............. & 84.0 & 7.5 & 11.5 & 2.6 & 31.3 & 47.1 & 6.1 & \multirow{6}{*}{9.5} & 0.66 & 83 \\
\hline Oats ...... & 87.4 & 2.9 & 14.2 & 6.6 & 9.8 & 66.4 & 2.0 & & 1.16 & 117 \\
\hline Barley ..................... & 87.6 & 2.6 & 14.3 & 1.9 & 5.2 & 76.1 & 3.1 & & 1.15 & 108 \\
\hline Molasses-beet pulp ............ & 87.1 & 6.9 & 13.4 & 0.5 & 14.2 & 64.9 & 24.6 & & 0.97 & 74 \\
\hline Dried poultry manure ........ & 92.7 & 21.8 & 33.1 & 2.0 & 18.4 & 24.7 & 0.7 & & 0.35 & 248 \\
\hline Soybean meal ................... & 85.2 & 6.1 & 53.1 & 1.1 & 6.1 & 33.6 & 9.1 & & 1.12 & 483 \\
\hline \multicolumn{11}{|l|}{ Experiment 2} \\
\hline Hay ............ & 86.9 & 6.8 & 9.1 & 1.8 & 31.3 & 51.1 & 12.4 & \multirow{6}{*}{1.2} & 0.62 & 60 \\
\hline Oats ......... & 89.5 & 3.0 & 15.0 & 5.7 & 11.1 & 65.2 & 2.1 & & 1.02 & 117 \\
\hline Barley ..................... & 88.6 & 2.4 & 13.1 & 2.3 & 5.0 & 76.8 & 3.7 & & 1.16 & 98 \\
\hline Molasses-beet pulp ............. & 87.5 & 7.3 & 13.1 & 0.5 & 15.6 & 63.9 & 22.9 & & 1.02 & 72 \\
\hline Dried poultry manure ........ & 90.9 & 33.5 & 17.9 & 2.9 & 19.2 & 26.5 & 0.3 & & 0.34 & 136 \\
\hline Soybean meal .................... & 87.7 & 6.0 & 49.5 & 1.3 & 6.1 & 37.0 & 10.6 & & 1.12 & 451 \\
\hline
\end{tabular}


of the dried poultry manure is shown in Table 3 and the mineral content of the experimental feeds in Table 4 . The mean feeding values of the different rations are given in Table $\mathbf{5}$.

Table 3. Amino acid composition of dehydrated poultry manure used in experiments.

\begin{tabular}{|c|c|c|}
\hline $\begin{array}{c}\text { Amino acid } \\
\mathrm{g} / 16 \mathrm{~g} \text { nitrogen }\end{array}$ & $\begin{array}{c}\text { Experiment } \\
1\end{array}$ & $\begin{array}{c}\text { Experiment } \\
2\end{array}$ \\
\hline Alanine ......................... & 2.5 & 4.1 \\
\hline 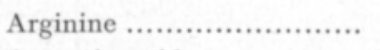 & 1.3 & 1.8 \\
\hline Aspartic acid ................ & 3.6 & 5.0 \\
\hline 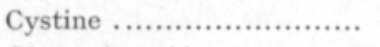 & 0.5 & 0.7 \\
\hline Glutamic acid ............... & 4.9 & 7.4 \\
\hline 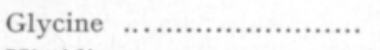 & 5.9 & 3.9 \\
\hline Histidine ..................... & 0.6 & 0.5 \\
\hline Isoleucine $. . . \ldots \ldots \ldots \ldots \ldots \ldots . . . . . . . .$. & 1.7 & 2.6 \\
\hline Leucine ......................... & 2.5 & 3.9 \\
\hline Lysine ........................... & 0.7 & 1.0 \\
\hline Methionine . ................... & 0.5 & 0.8 \\
\hline Phenylalanine ................ & 1.5 & 2.4 \\
\hline 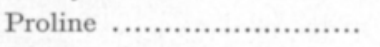 & 2.1 & 3.1 \\
\hline 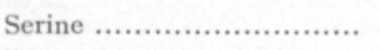 & 1.0 & 1.6 \\
\hline Threonine ........................ & 1.5 & 2.5 \\
\hline 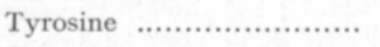 & 1.8 & 2.8 \\
\hline Valine ............................ & 2.1 & 3.4 \\
\hline
\end{tabular}

Table 4. Mineral composition of the experimental feeds.

\begin{tabular}{|c|c|c|c|c|c|c|c|c|c|}
\hline \multirow[t]{2}{*}{ Experiment $\underline{1}$} & \multicolumn{3}{|c|}{$\mathrm{g} / \mathrm{kg} \mathrm{DM}$} & \multicolumn{6}{|c|}{$\mathrm{mg} / \mathrm{kg} \mathrm{DM}$} \\
\hline & $\mathrm{Ca}$ & $\mathbf{P}$ & $\mathrm{Mg}$ & K & $\mathrm{Na}$ & $\mathrm{Fe}$ & $\mathrm{Cu}$ & $\mathrm{Zn}$ & Mn \\
\hline Hay ............ & 2.73 & 2.62 & 0.70 & 25.24 & 1.93 & 149 & 9 & 48 & 43 \\
\hline Oats ............................ & 0.75 & 3.74 & 1.08 & 4.06 & 0.10 & 98 & 4 & 55 & 43 \\
\hline Barley ........................ & 0.49 & 3.55 & 1.10 & 5.21 & 0.13 & 88 & 7 & 66 & 21 \\
\hline Molasses-beet pulp .... & 6.51 & 0.85 & 4.05 & 17.68 & 1.66 & 325 & 7 & 24 & 46 \\
\hline Dried poultry manure & 58.73 & 17.96 & 5.41 & 13.41 & 4.84 & 995 & 12 & 305 & 251 \\
\hline Soybean meal ............. & 2.82 & 6.76 & 3.00 & 24.70 & 0.10 & 117 & 17 & 63 & 56 \\
\hline
\end{tabular}

Experiment 2

\begin{tabular}{|c|c|c|c|c|c|c|c|c|c|}
\hline & $\mathrm{Ca}$ & $\mathbf{P}$ & $\mathrm{Mg}$ & K & $\mathrm{Na}$ & $\mathrm{Fe}$ & $\mathrm{Cu}$ & $\mathrm{Zn}$ & Mn \\
\hline Hay .. & 2.55 & 2.47 & 0.73 & 26.56 & 4.88 & 112 & 21 & 50 & 44 \\
\hline 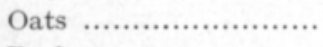 & 0.83 & 2.97 & 0.89 & 4.51 & 0.09 & 83 & 8 & 64 & 42 \\
\hline Barley ......................... & 0.72 & 3.17 & 1.12 & 5.80 & 0.18 & 100 & 8 & 71 & 24 \\
\hline Molasses-beet pulp .... & 4.44 & 0.84 & 3.54 & 18.79 & 0.47 & 288 & 10 & 27 & 43 \\
\hline Dried poultry manure & 69.11 & 25.74 & 6.20 & 18.52 & 5.62 & 2334 & 145 & 486 & 463 \\
\hline Soybean meal ............. & 2.63 & 6.72 & 3.00 & 22.50 & 0.19 & 296 & 20 & 64 & 44 \\
\hline
\end{tabular}


Table 5. The average feeding values of the different diets.

Experiment 1

\begin{tabular}{|c|c|c|c|c|c|c|c|}
\hline \multirow{2}{*}{ Group } & \multicolumn{2}{|c|}{ DPM1 } & \multicolumn{2}{|c|}{ SBM1 } & \multicolumn{2}{|c|}{ UREA1 } & \multirow[b]{2}{*}{ SEM } \\
\hline & $\overline{\mathrm{x}}$ & S.D. & $\overline{\mathbf{x}}$ & S.D. & $\overline{\mathbf{x}}$ & S.D. & \\
\hline FU/100 kg DM ................. & $86.22^{\mathrm{e}}$ & 1.07 & $95.71^{\mathrm{d}}$ & 2.40 & $94.42^{\mathrm{d}}$ & 2.00 & 4.33 \\
\hline kg DM/FU ....................... & $1.16^{\mathrm{d}}$ & 0.01 & $1.06^{\mathrm{e}}$ & 0.03 & $1.06^{\mathrm{e}}$ & 0.02 & 0.05 \\
\hline $\mathrm{DCP}, \%$ in $\mathrm{DM}$ & $11.8^{\mathrm{a}}$ & 0.2 & $11.9^{\mathrm{a}}$ & 0.3 & $11.8^{\mathrm{a}}$ & 0.2 & 0.24 \\
\hline DCP, g/FU ................. 1 & $137^{d}$ & 0.6 & $124^{\mathrm{e}}$ & 0.1 & $125^{\circ}$ & 0.04 & 5.6 \\
\hline Crude fibre, $\%$ in DM ....... & $17.5^{\mathrm{a}}$ & 0.7 & $16.6^{\mathrm{a}}$ & 1.2 & $16.8^{\mathrm{a}}$ & 1.0 & 1.00 \\
\hline Sugars, $\%$ in DM .............. & $5.0^{\mathrm{ae}}$ & 0.07 & $5.8^{\mathrm{d}}$ & 0.05 & $5.2^{\mathrm{ae}}$ & 0.06 & 0.32 \\
\hline Urea, $\%$ in DM $\ldots \ldots \ldots \ldots . . .$. & & & & & 1.06 & 0.08 & \\
\hline DCP, $\%$ of urea .............. & & & & & 1.75 & 0.11 & \\
\hline DCP, g of urea $\ldots \ldots \ldots \ldots \ldots$ & & & & & 273 & 53 & \\
\hline Experiment $\underline{2}$ & DP & & SB. & & UR & $\mathrm{A} 2$ & \\
\hline FU/100 kg DM ................. & $81.82^{\mathrm{e}}$ & 0.49 & $90.72^{\mathrm{d}}$ & 0.57 & $88.30^{\mathrm{d}}$ & 1.26 & 3.73 \\
\hline 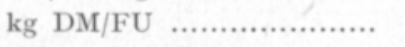 & $1.22^{\mathrm{d}}$ & 0.01 & $1.10^{\mathrm{e}}$ & 0.01 & $1.13^{\mathrm{e}}$ & 0.05 & 0.05 \\
\hline $\mathrm{DCP}, \%$ in $\mathrm{DM} \ldots \ldots \ldots \ldots \ldots$ & $9.1^{\mathrm{c}}$ & 0.09 & $10.7^{\mathrm{d}}$ & 0.1 & $10.4^{\mathrm{d}}$ & 0.2 & 0.69 \\
\hline DCP, g/FU .................. 1 & $111^{\mathrm{e}}$ & 0.4 & $118^{d}$ & 0.3 & $117^{\mathrm{d}}$ & 0.7 & 3.0 \\
\hline Crude fibre, $\%$ ib DM ..... & $18.5^{\mathrm{ab}}$ & 0.3 & $17.4^{\mathrm{ac}}$ & 0.3 & $18.9^{\mathrm{bd}}$ & 0.6 & 0.63 \\
\hline Sugars, $\%$ in DM .............. & $7.5^{\mathrm{e}}$ & 0.14 & $8.4^{\mathrm{d}}$ & 0.11 & $8.1^{\mathrm{d}}$ & 0.23 & 0.41 \\
\hline Urea, $\%$ in DM .............. & & & & & 0.99 & 0.08 & \\
\hline DCP, $\%$ of urea ............... & & & & & 1.84 & 0.11 & \\
\hline DCP, $g$ of urea ............... & & & & & 274 & 48 & \\
\hline
\end{tabular}

Means with different letters were significantly different.

a, b $(\mathrm{P}<0.05)$, c, d, e $(\mathrm{P}<0.01)$

$\mathrm{SEM}=$ standard error of means

In Expt. 1 the DPM had a high uric acid content averaging $9.5 \%$ of DM, and in Expt. 2 a very low value of $1.2 \%$. During storage or dehydration there may have been losses of nitrogen due to fermentation or high temperatures. Moreover the energy (FU) and digestible crude protein (DCP) value of the DPM in Expt. 1 were also better than that in Expt. 2 because of the high ash content, $33.5 \%$ in the latter. In both cases the DPM was of poorer mutritive value than that analysed earlier (NÄsI 1976), but comparable in composition to DPMs described in the literature (Appendix 1).

The amino acid contents of the poultry manures expressed as $\mathrm{g} / 100 \mathrm{~g}$ crude protein were quite similar in both experiments. These correspond with values reported by FLEgAL and ZINDEL (1970), BIELY et al. (1973), Blair and Knight (1973 a), McNAB et al. (1974), NÄsi (1976). The ash content was high and the mineral composition rich: $\mathrm{Ca} 58.7-69.1, \mathrm{P} 18.0-25.7, \mathrm{Mg}$ $5.4-6.2 \mathrm{~g} / \mathrm{kg}$ DM and Fe $995-2334 \mathrm{mg} / \mathrm{kg}$ DM.

The average energy value, $\mathrm{FU} / 100 \mathrm{~kg} \mathrm{DM}$ of the experimental rations was significantly lower $(\mathrm{P}<0.01)$ in groups DPM1 and DPM2 than in the other groups, owing to the low energy values of the $20 \%$ DPM included in the concentrate mixture. The precent of digestible crude protein in the DM was the same, 11.8-11.9\%, in all groups in Expt. 1 but in Expt. 2 the DPM group had a significantly $(\mathrm{P}<0.01)$ lower value of $9.1 \%$, as against 10.7 
and 10.4 for SBM2 and UREA2, respecvitely. The crude fibre content in DPM1 and DPM2 was higher than in the other groups and significantly different $(\mathrm{P}<0.01)$ between DPM2 and SBM2.

The sugar content of the DM was lower in the DPM groups than in the other groups and in Expt. 2 the difference was significant $(\mathrm{P}<0.01)$.

Urea content was on average $1.06 \%$ in UREA1 and $0.99 \%$ in UREA2 groups.

Averages $(\overline{\mathbf{x}})$ and standard deviations (S.D.) of consumption of different feedstuffs in kg DM, calculated according to FU and DCP supply, are presented in Tables 6 and 7, and total intake of DM and this as a percentage of live weight are presented in Figures 1 and 2 . The feed refusals for the concentrate were quite small during the experiment except with the DPM1 and DPM2 groups, which refused the concentrate particularly during the first part of the experiment. The intake of the concentrate mixture in group DPM1, as a percentage of the feed offered, was significantly $(\mathrm{P}<0.01)$ lower than SBM1 and UREA1, and DPM2 lower than SBM2 $(\mathrm{P}<0.01)$ and UREA2 $(\mathrm{P}<0.05)$. Palatability of UREA2 was lower $(\mathrm{P}<0.05)$ than that of SBM2. The average percents of concentrate mixture intake were $90.7,97.5,98.8$ for DPM1, SBM1 UREA1 and 85.5, 97.8, 92.4 for DPM2, SBM2 and UREA2, respectively (Figures 1 and 2). The quantities of hay offered were the same for all groups. The palatability of hay was found to be higher $(\mathrm{P}<0.01)$ for UREA1 than the other groups of Expt. 1, the perscentages being 94.2, 95.0, 97.2\% for DPM1, SBM1 and UREA1; in Expt. 2 the palatabilities were alike at 96.0, 96.9 and $96.3 \%$ for DPM2, SBM2 and UREA2. At the beginning of Expt. 1 the palatability of the DPM concentrate was $84.6 \%$ and at the end $93.0 \%$, calculated as two weekly averages. During the experimental period one cow consumed only $63.7-75.8 \%$. The palatability fluctuated throughout Expt. 2. Two cows in group DPM2 ate, on average, less than $80 \%$ of their ration during the experimental period. The palatability of the urea concentrate was good in both experiments for all except one cow in the UREA2 group which consumed on average only $74.3 \%$ of feed offered during the trial.

Table 6. The mean daily intake of different feeds in the experimental period $\mathrm{kg}$ DM/cow. Experiment 1

\begin{tabular}{|c|c|c|c|c|c|c|c|c|c|}
\hline \multirow{2}{*}{ Groups } & \multicolumn{3}{|c|}{ DPM1 } & \multicolumn{3}{|c|}{ SBM1 } & \multicolumn{3}{|c|}{ UREA1 } \\
\hline & $\overline{\mathbf{x}}$ & S.D. $\%$ & of DM & $\overline{\mathbf{x}}$ & S.D. $\%$ & of DM & $\bar{x}$ & S.D. & pf DM \\
\hline 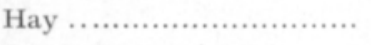 & 4.75 & 0.11 & 34.4 & 4.78 & 0.13 & 36.2 & 4.90 & 0.04 & 37.9 \\
\hline Concentrate mixture ........ & 9.27 & 1.40 & 65.6 & 8.50 & 1.79 & 63.8 & 8.22 & 1.53 & 62.1 \\
\hline 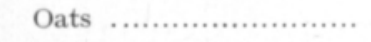 & 3.21 & 0.49 & 22.7 & 3.41 & $0.72-$ & 25.6 & 3.63 & 0.68 & 27.4 \\
\hline Barley ......................... & 3.21 & 0.49 & 22.7 & 3.41 & 0.72 & 25.6 & 3.63 & 0.68 & 27.4 \\
\hline Molasses-beet pulp ...... & 0.91 & 0.14 & 6.4 & 0.93 & 0.19 & 7.0 & 0.82 & 0.15 & 6.2 \\
\hline Dried poultry manure & 1.94 & 0.36 & 13.8 & - & & & - & & \\
\hline Soybean meal .............. & - & & & 0.75 & 0.17 & 5.6 & - & & \\
\hline Urea $\ldots \ldots \ldots \ldots \ldots \ldots \ldots . . . . . . . . . .$. & - & & & - & & & 0.14 & 0.03 & 1.1 \\
\hline Total dry matter, kg ....... & 14.03 & 1.39 & 100.0 & 13.27 & 1.74 & 100.0 & 13.11 & 1.53 & 100.0 \\
\hline
\end{tabular}


Experiment 2

\begin{tabular}{|c|c|c|c|c|c|c|c|c|c|}
\hline \multirow{2}{*}{ Groups } & \multicolumn{3}{|c|}{ DPM2 } & \multicolumn{3}{|c|}{ SBM2 } & \multicolumn{3}{|c|}{ UREA2 } \\
\hline & $\bar{x}$ & S.D \% & of DM & $\overline{\mathrm{x}}$ & S.D. $\%$ & of DM & $\overline{\mathrm{x}}$ & S.D. $\%$ & of DM \\
\hline Hay & 5.90 & 0.17 & 37.5 & 5.94 & 0.07 & 39.2 & 5.90 & 0.18 & 41.7 \\
\hline Concentrate mixture & 9.90 & 0.77 & 62.5 & 9.24 & 0.39 & 60.8 & 8.34 & 0.95 & 58.3 \\
\hline Oats ............ & 3.47 & 0.26 & 22.0 & 3.73 & 0.16 & 24.5 & 3.71 & 0.42 & 25.9 \\
\hline Barley ....................... & 3.44 & 0.26 & 21.7 & 3.69 & 0.16 & 24.3 & 3.67 & 0.13 & 25.6 \\
\hline Molasses-beet pulp ...... & 0.96 & 0.08 & 6.1 & 0.91 & 0.04 & 6.0 & 0.82 & 0.09 & 5.8 \\
\hline Dried poultry manure & 2.00 & 0.18 & 12.7 & - & & & - & & \\
\hline Soybean meal .............. & - & & & 0.91 & 0.04 & 6.0 & - & & \\
\hline 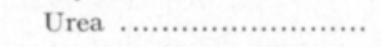 & - & & & - & & & 0.14 & 0.02 & 1.0 \\
\hline Total dry matter, kg ....... & 15.77 & 0.85 & 100.0 & 15.19 & 0.33 & 100.0 & 14.25 & 0.96 & 100.0 \\
\hline
\end{tabular}

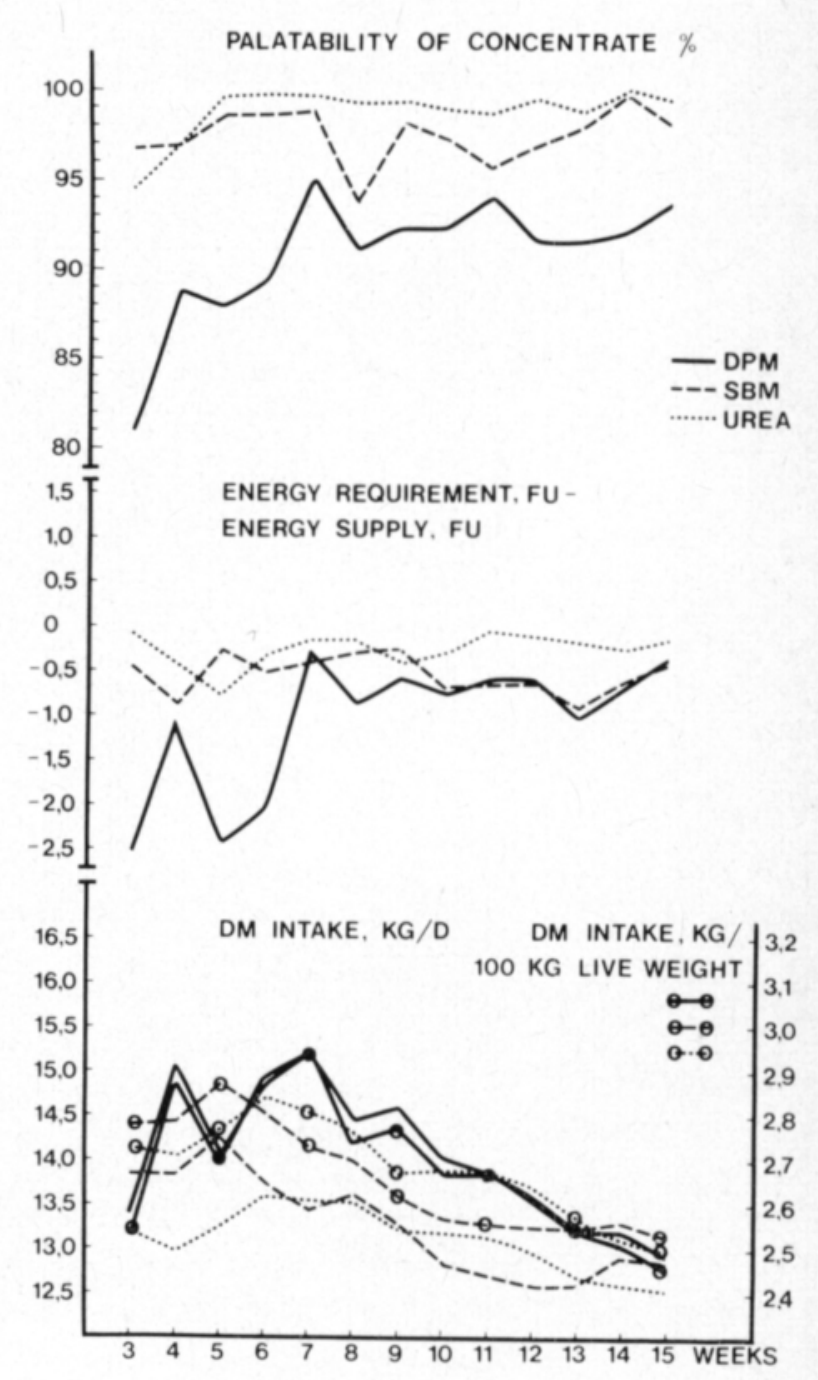

Fig. 1. Palatability of concentrate mixture, energy supply and dry matter intake. Experiment 1. 


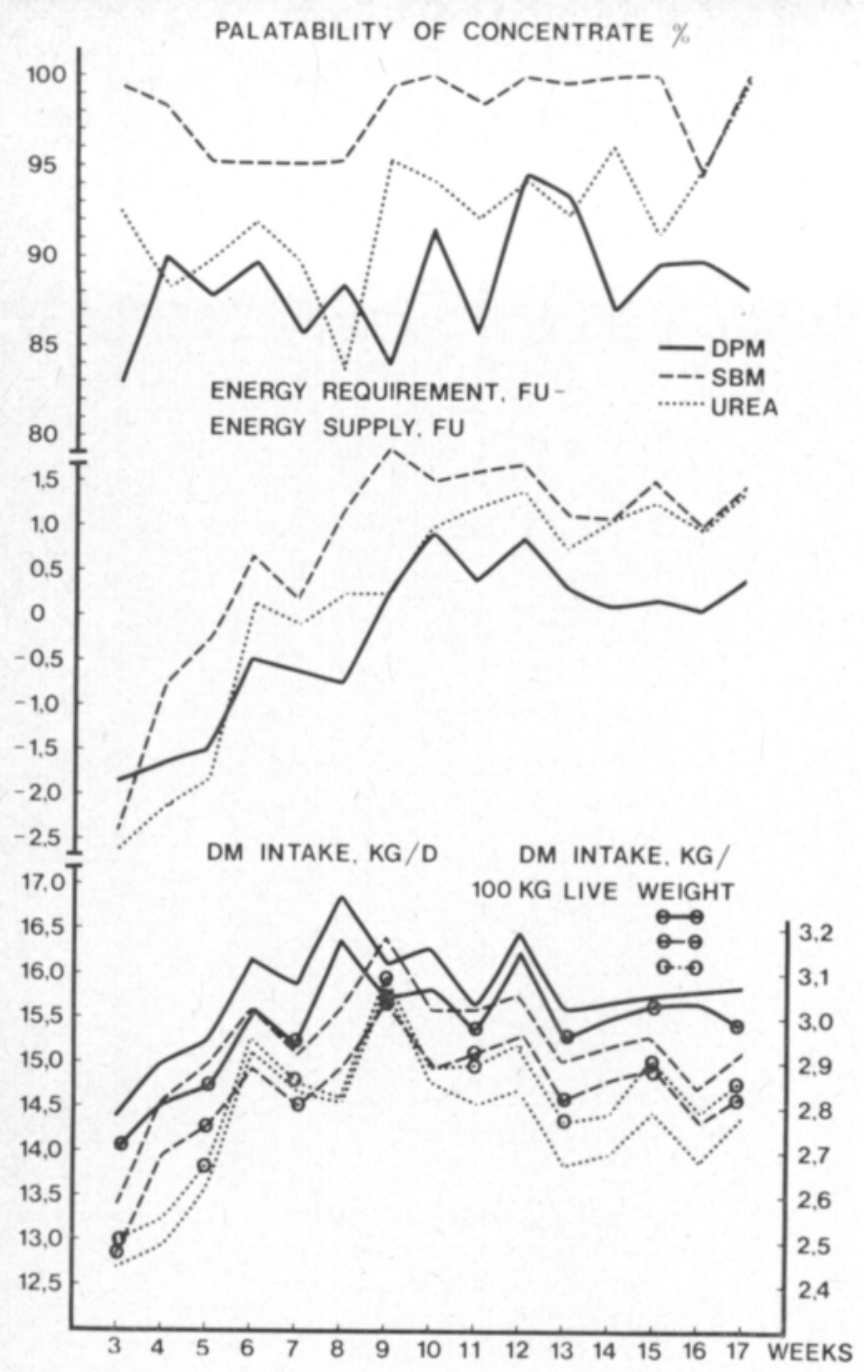

Fig. 2. Palatability of concentrate mixture, energy supply and dry matter intake. Experiment 2 .

High level voluntary intake is of equal importance to other factors in achieving satisfactory animal performance. Difficulties have sometimes been reported in achieving adequate levels of consumption with rations containing DPM (Bucholtz et al. 1971, Bull and Reid 1971, Tinnimit et al. 1972, Thomas et al. 1972, Silva et al. 1976, Sмith et al. 1976). Here adaptation periods of 1-3 weeks were necessary before maximal levels of intake were achieved. Bucholtz et al. (1971) observed that steers descriminated against DPM and sorted out maize silage. Such sorting and adaptation difficulties can be eliminated by pelleting combinate rations (SILvA et al. 1976, Sмiтн et al. 1976).

The average DPM intake in $\mathrm{kg}$ DM/day was 1.94 and 2.00 in Experiments 1 and 2 . The maximum intake of DPM was $2.85 \mathrm{~kg} \mathrm{DM} /$ day/cow, and the average uric acid intake was $186 \mathrm{~g}$ and $24 \mathrm{~g} /$ day in DPM1 and DPM2 respec- 
tively. By comprison, the average urea intake in Expts. 1 and 2 was 140 g/day/cow. The DPM intakes are comparable with the $2 . \overline{2} \mathrm{~kg}$ reported by Thomas et al. (1972) and $2.5-3.08 \mathrm{~kg}$ by Silva et al. (1976) but lower than the values reported by Bull and Reid (1971), Claesson and Ahlström (1974) and Kristensen et al. (1976).

The percentages of roughage and concentrate were, on average, 36 and 64 in Expt. 1 and 39 and 61 in Expt. 2 calculated on a DM basis.

The average nutrient intakes are presented in Table 7. On average, total DM intakes were $14.0,13.3$ and $13.1 \mathrm{~kg}$ in DPM1, SPM1 and UREA1 and the differences were not significant. The corresponding values for Expt. 2 were 15.8, 15.2 and 14.3 in DPM2, SBM2 and UREA2, the difference between DPM2 and SBM2 and between DPM2 and UREA2 being significant at $\mathrm{P}<0.05$ and $\mathrm{P}<0.01$, respectively. DM intakes expressed as percentages of the liveweight did not differ $(\mathrm{P}>0.05)$ between groups. Energy supply, FU, and protein supply, DCP, did not differ $(\mathrm{P}>0.05)$ between groups. The protein proportion provided by the DCP was $29.0,22.5$ and $17.5 \%$ in DPM1, SBM1 and UREA1 and 19.0, 25.2 and $18.4 \%$ in DPM2, SBM2 and UREA2. Differences between groups were significant $(\mathrm{P}<0.05, \mathrm{P}<0.01)$. Crude fibre intake was higher in DPM1 and DPM2 $(\mathrm{P}<0.05, \mathrm{P}<0.01)$ than in the other groups. The intake of sugars, $\mathrm{g} /$ day was higher $(\mathrm{P}<0.01)$ in SBM2 than in DPM2 and UREA2.

Calculated intakes of minerals and trace elements are given in Table 8 .

The mineral supplement for the DPM groups was $5 \mathrm{~g} / \mathrm{kg}$ milk and $10 \mathrm{~g} / \mathrm{kg}$ milk for the SBM and UREA groups. The calcium provision was about for times as great and phosphorus almost twice as great with the DPM diet as with the other diets. Provisions of iron, zinc and manganese were likewise greater for the DPM diets than the others. The mineral content of DPM was rich.

Table 7. Nutrient consumption during the experimental period.

\begin{tabular}{|c|c|c|c|c|c|c|c|}
\hline \multirow{2}{*}{ Experiment $\underline{1}$} & \multicolumn{2}{|c|}{ DPM1 } & \multicolumn{2}{|c|}{ SBM1 } & \multicolumn{2}{|c|}{ UREA1 } & \multirow{2}{*}{ SEM } \\
\hline & $\overline{\mathbf{x}}$ & S.D. & $\overline{\mathbf{x}}$ & S.D. & $\overline{\mathbf{x}}$ & S.D. & \\
\hline Total dry matter intake, $\mathrm{kg}$ & $14.03^{\mathrm{a}}$ & 1.39 & $13.27^{\mathrm{a}}$ & 1.74 & $13.11^{\mathrm{a}}$ & 1.53 & 1.50 \\
\hline $\mathrm{kg} \mathrm{DM} / 100 \mathrm{~kg}$ live weight ... & $2.68^{a}$ & 0.18 & $2.66^{\mathrm{a}}$ & 0.29 & $2.68^{\mathrm{a}}$ & 0.29 & 0.24 \\
\hline Energy supply, FU ............. & $12.12^{\mathrm{a}}$ & 1.35 & $12.76^{\mathrm{a}}$ & 1.99 & $12.41^{\mathrm{a}}$ & 1.71 & 1.61 \\
\hline forages, $\%$ & $26.4^{\mathrm{a}}$ & 3.0 & $25.5^{\mathrm{a}}$ & 4.1 & $26.6^{\mathrm{a}}$ & 3.6 & 3.4 \\
\hline concentrates, $\%$................. & $73.6^{\mathrm{a}}$ & 3.0 & $74.5^{\mathrm{a}}$ & 4.1 & $73.4^{\mathrm{a}}$ & 3.6 & 3.4 \\
\hline Digestible crude protein, $g$... & $1666^{\mathrm{a}}$ & 192 & $1588^{\mathrm{a}}$ & 249 & $1553^{\mathrm{a}}$ & 249 & 209 \\
\hline forages, $\%$...................... & $23.8^{\mathrm{a}}$ & 2.8 & $25.4^{\mathrm{a}}$ & 4.1 & $26.4^{\mathrm{a}}$ & 3.6 & 3.4 \\
\hline 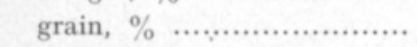 & $47.2^{\mathrm{ac}}$ & 1.7 & $52.2^{\mathrm{b}}$ & 2.8 & $56.2^{\mathrm{bd}}$ & 2.8 & 4.1 \\
\hline protein supplement, $\% \ldots \ldots$ & $29.0^{\mathrm{e}}$ & 1.0 & $22.4^{\mathrm{d}}$ & 1.2 & $17.4^{\mathrm{e}}$ & 0.8 & 4.5 \\
\hline Crude fibre, $g$................... & $2450^{b}$ & 146 & $2183^{a}$ & 132 & $2189^{a}$ & 121 & 170 \\
\hline 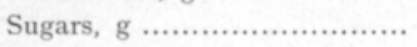 & $694^{a}$ & 60 & $765^{a}$ & 94 & $687^{a}$ & 71 & 79 \\
\hline Uric acid, $g$...................... & 186 & 31 & - & & - & & \\
\hline 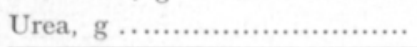 & - & & - & & 140 & 3 & \\
\hline
\end{tabular}


DPM2 SBM2 UREA2

\begin{tabular}{|c|c|c|c|c|c|c|c|}
\hline Cotal dry matter intake, kg & $15.77^{\mathrm{bd}}$ & 0.85 & $15.19^{\mathrm{ab}}$ & 0.33 & $14.25^{\mathrm{ac}}$ & 0.96 & 0.98 \\
\hline DM/100 kg live weight $\ldots$ & $2.98^{\mathrm{a}}$ & 0.12 & $2.83^{\mathrm{a}}$ & 0.25 & $2.82^{\mathrm{a}}$ & 0.34 & 1.14 \\
\hline ergy supply, FU ............ & $12.92^{\mathrm{a}}$ & 0.76 & $13.79^{\mathrm{a}}$ & 0.39 & $12.61^{\mathrm{a}}$ & 1.01 & 0.89 \\
\hline 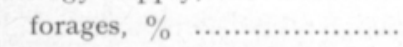 & $28.9^{\mathrm{a}}$ & 1.4 & $27.2^{\mathrm{a}}$ & 1.1 & $29.8^{\mathrm{a}}$ & 2.4 & 2.0 \\
\hline concentrates, $\%$................ & $71.1^{\mathrm{a}}$ & 1.4 & $72.8^{\mathrm{a}}$ & 1.1 & $70.2^{\mathrm{a}}$ & 2.4 & 2.0 \\
\hline Digestible crude protein, $g$... & $1438^{\mathrm{a}}$ & 89 & $1630^{b}$ & 50 & $1480^{\mathrm{a}}$ & 128 & 122 \\
\hline forages, $\%$..................... & $24.7^{\mathrm{d}}$ & 1.3 & $22.0^{\mathrm{e}}$ & 1.0 & $24.3^{\mathrm{d}}$ & 2.1 & 1.4 \\
\hline grain, $\%$........................... & $56.30^{d}$ & 0.9 & $52.8^{\mathrm{e}}$ & 0.7 & $57.3^{\mathrm{d}}$ & 1.6 & 2.1 \\
\hline protein supplement, $\%$...... & $19.0^{\mathrm{e}}$ & 0.4 & $25.2^{\mathrm{d}}$ & 0.3 & $18.4^{\mathrm{e}}$ & 0.5 & 2.9 \\
\hline Grude fibre, $\mathrm{g} \ldots \ldots \ldots \ldots \ldots \ldots \ldots \ldots \ldots \ldots \ldots \ldots$ & $2918^{e}$ & 119 & $2636^{\mathrm{ad}}$ & 19 & $2553^{\mathrm{ad}}$ & 98 & 179 \\
\hline 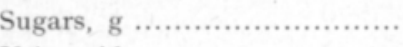 & $1183^{\mathrm{ac}}$ & 48 & $1280^{\mathrm{d}}$ & 15 & $1157^{\mathrm{ac}}$ & 51 & 65 \\
\hline Jric acid, $g$..................... & 24 & 2 & - & & - & & \\
\hline ea, $g$ & - & & - & & 141 & 2 & \\
\hline
\end{tabular}

Mean with different letter were significantly different.

a, b $(\mathrm{P}<0.05)$, c. d, e $(\mathrm{P}<0.01)$.

Table 8. Calculated mean daily intake of minerals and trace elements obtained from feeds and mineral supplements.

\begin{tabular}{|c|c|c|c|c|c|c|c|c|c|c|c|c|}
\hline \multirow{3}{*}{ Groups } & \multicolumn{6}{|c|}{ Experiment 1} & \multicolumn{6}{|c|}{ Experiment 2} \\
\hline & \multicolumn{2}{|c|}{ DPM1 } & \multicolumn{2}{|c|}{ SBM1 } & \multicolumn{2}{|c|}{ UREA1 } & \multicolumn{2}{|c|}{ DPM2 } & \multicolumn{2}{|c|}{ SBM2 } & \multicolumn{2}{|c|}{ UREA2 } \\
\hline & $\overline{\mathrm{x}}$ & S.D. & $\overline{\mathrm{x}}$ & S.D. & $\bar{x}$ & S.D. & $\overline{\mathrm{x}}$ & S.D. & $\bar{x}$ & S.D. & $\bar{x}$ & S.D. \\
\hline Calcium, g/d & 144.6 & 26.4 & 42.3 & 7.9 & 39.3 & 6.2 & 172.0 & 26.1 & 43.2 & 3.3 & 39.7 & 4.8 \\
\hline Phosphorus, g/d & 76.1 & $12 \cdot 3$ & 53.7 & 9.7 & 50.0 & 7.5 & 92.8 & 10.3 & 54.4 & 5.4 & 47.6 & 6.9 \\
\hline Magnesium, g/d & 27.9 & 4.7 & 24.4 & 5.1 & 21.9 & 3.8 & 30.5 & 3.4 & 24.9 & 2.3 & 21.5 & 3.2 \\
\hline Sodium, g/d & 35.4 & 9.4 & 38.2 & 10.2 & 37.5 & 9.6 & 59.6 & 37.9 & 59.1 & 37.2 & 58.0 & 38.1 \\
\hline Potassium, g/d & 189.7 & 18.1 & 186.1 & 18.2 & 170.5 & 14.8 & 249.3 & 31.0 & 235.2 & 31.0 & 211.9 & 27.5 \\
\hline Iron, $\mathrm{mg} / \mathrm{d}$ & 3851 & 804 & 2580 & 726 & 2476 & 656 & 6835 & 814 & 2769 & 312 & 2438 & 372 \\
\hline Copper, mg/d & 138 & 22 & 167 & 33 & 155 & 28 & 525 & 150 & 289 & 122 & 266 & 121 \\
\hline Zinc, mg/d & 1392 & 228 & 1052 & 159 & 1022 & 168 & 1916 & 251 & 1199 & 166 & 1122 & 200 \\
\hline Manganese, mg/d & 939 & 132 & 505 & 72 & 477 & 65 & 1450 & 159 & 583 & 77 & 536 & 80 \\
\hline
\end{tabular}

\subsubsection{Digestibilities of the rations}

Data on the apparent digestibilities of the experimental rations in Expt. 1 are given in Table 9. The dry matter, organic matter, crude fibre, crude fat

Table 9. Apparent digestibility of the different rations in Experiment 1.

\begin{tabular}{|c|c|c|c|}
\hline Groups & DPM1 & SBM1 & UREA1 \\
\hline 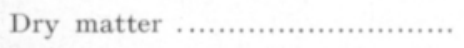 & $69.9^{\mathrm{a}}$ & $72.0^{\mathrm{ab}}$ & $74.0^{\mathrm{b}}$ \\
\hline 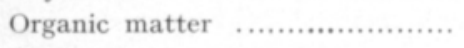 & $70.6^{\mathrm{ad}}$ & 73.1 abde & $75.0^{\text {be }}$ \\
\hline 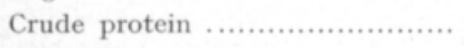 & $72.3^{\text {ade }}$ & $71.8^{\mathrm{ad}}$ & $75.9^{\text {be }}$ \\
\hline 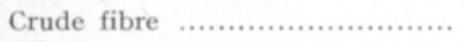 & $57.4 \mathrm{a}$ & $56.7^{\mathrm{a}}$ & $59.7^{\mathrm{a}}$ \\
\hline Ether extract $\ldots \ldots \ldots \ldots \ldots \ldots \ldots \ldots \ldots \ldots \ldots \ldots \ldots \ldots$ & $74.1^{\mathrm{a}}$ & $75.5^{\mathrm{a}}$ & $77.6^{\mathrm{a}}$ \\
\hline Nitrogen free extract $\ldots . \ldots \ldots \ldots \ldots$ & $75.9^{\mathrm{a}}$ & $77.7 \mathrm{ab}$ & $80.0^{\mathrm{b}}$ \\
\hline
\end{tabular}

Means with different letters were significantly different.

a, b $(\mathrm{P}<0.05)$ d, e $(\mathrm{P}<0.01)$ 
and NFE digestibilities were lower in the diet including $20 \%$ DPM than in the other diets. The digestibility of the organic matter was $4.4 \%$ lower in the DPM diet than in the UREA diet, the difference being significant $(\mathrm{P}<0.01)$. The organic matter digestibility of the DPM diet was only $0.7 \%$ lower than the dry matter digestibility, indicating a high solubility of the minerals in DPM. The crude protein digestibility of the UREA diet was higher $(\mathrm{P}<0.01)$ than that of the SBM and DPM diets $(\mathrm{P}<0.05)$. NPN-components constitute the major part of the nitrogen in poultry manure, making the general digestibility of the crude protein high, as set forth in the literature (EL-SABBAN et al. 1970, Lowman and KNight 1970, Tinnimit et al. 1972). The digestibility of DPM decrease as its proportion in the diet increases (PARIGI-BINI 1969, Lowman and KNight 1970, Thomas 1970). DM intakes during collection periods were on average $14.9,13.6$ and $13.6 \mathrm{~kg}$ for DPM1, SBM1 and UREA1. Generally as feed intakes are increased, digestibilities are depressed (EKERN 1972, RoBERTSon et al. 1974, VANEs 1976).

The DM digestibilities of DPM reported in the literature normally vary between 57 and $65 \%$, this range being lower than the DM digestibilities of grain and good quality hay. DPM supplementation in high proportion is therefore not feasible because of the low energy value.

\section{1.3. Milk yield and feed utilisation}

Averages and standard deviations of the daily yield and chemical composition of milk are presented in Table 10 and Figures 3-6. The differences in milk yield and milk constituents between groups during the experimental period were not statistically significant $(\mathrm{P}>0.05)$. The differences between groups were greater, however, during Expt. 2.

The non-significance of diet effects for these measures have been due to sample size and variation among cows. The mean daily milk production of cows fed diets containing DPM was generally slightly lower than production of cows on SBM. Milk fat content was not clearly influenced by feeding DPM, as noted also by Smith and WheELER (1979).

One cow of the SBM group was withdrawn from the experiment because of mastitis, and the average results for the SBM2 group are based on five cows. The CMT-value of milk in the SBM2 group, $(1.76)$ was higher $(\mathrm{P}<0.05)$ than in the DPM2 (1.22) or UREA2 group (1.34). The production data is thus difficult to compare directly.

The composition of the milk was clearly related to the lactation stage. The fat percent decreased $(\mathrm{P}<0.05)$ in all groups, the protein percent increased $(\mathrm{P}<0.05)$ in Expt. 1 and $(\mathrm{P}<0.01)$ in Expt. 2 , and the lactose content decreased very significantly $(\mathrm{P}<0.001)$ during the experimental period. The dry matter content of milk decreased only slightly in Expt. 1 but very significantly $(\mathrm{P}<0.001)$ in Expt. 2. There was also a strong correlation between milk yield and many consitutuents of the milk, but few of the correlations were linear in either experiment when time was eliminated.

The average milk yield declined $(\%)(\mathrm{P}<0.05)$ in DPM1 $(-1.94)$ compared with SBM1 $(-1.03)$ and UREA1 $(-0.95)$. The corresponding values for 
Table 10. Mean daily milk yield and composition.

\begin{tabular}{ccccccccc}
\hline \multirow{2}{*}{ Groups } & \multicolumn{3}{c}{ DPM1 } & \multicolumn{3}{c}{ SBM1 } & \multicolumn{3}{c}{ UREA1 } \\
\cline { 2 - 9 } & & $\bar{x}$ & S.D. & $\bar{x}$ & S.D. & $\bar{x}$ & S.D. & SEM \\
\hline
\end{tabular}

Experiment 1
Milk yield $/ d$

\begin{tabular}{|c|c|c|c|c|c|c|c|}
\hline Milk yield, $\mathrm{kg}$................. & $20.4^{\mathrm{a}}$ & 2.5 & $21.4^{\mathrm{a}}$ & 5.0 & $20.3^{\mathrm{a}}$ & 4.1 & 3.7 \\
\hline 4 \% FCM, kg .................. & $22.7^{\mathrm{a}}$ & 3.7 & $23.2^{\mathrm{a}}$ & 5.5 & $21.7^{a}$ & 4.4 & 4.3 \\
\hline Milk dry matter, $g$. .......... & $2782^{a}$ & 398 & $2889^{\mathrm{a}}$ & 627 & $2177^{\mathrm{a}}$ & 509 & 491 \\
\hline 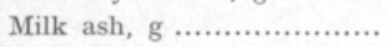 & $126^{\mathrm{a}}$ & 16 & $139^{\mathrm{a}}$ & 28 & $129^{\mathrm{a}}$ & 27 & 23 \\
\hline Milk fat, $g$...................... & $966^{\mathrm{a}}$ & 188 & $979^{\mathrm{a}}$ & 238 & $906^{\mathrm{a}}$ & 190 & 195 \\
\hline Milk protein, $g$. ................. & $706^{\mathrm{a}}$ & 96 & $748^{\mathrm{a}}$ & 161 & $677^{\mathrm{a}}$ & 118 & 122 \\
\hline Milk sugar, $g$............... & $998^{\mathrm{a}}$ & 118 & $1049^{\mathrm{a}}$ & 224 & $993^{\mathrm{a}}$ & 189 & 175 \\
\hline
\end{tabular}

Milk composition

\begin{tabular}{lrrrrrrr} 
Milk dry matter, $\% \ldots \ldots \ldots$. & $13.60^{\mathrm{a}}$ & 0.48 & $13.57^{\mathrm{a}}$ & 0.51 & $13.21^{\mathrm{a}}$ & 0.38 & 0.46 \\
Milk ash, $\% \ldots \ldots \ldots \ldots \ldots \ldots$ & $0.63^{\mathrm{a}}$ & 0.02 & $0.65^{\mathrm{a}}$ & 0.03 & $0.63^{\mathrm{a}}$ & 0.02 & 0.03 \\
Milk fat, $\% \ldots \ldots \ldots \ldots \ldots \ldots$. & $4.69^{\mathrm{a}}$ & 0.51 & $4.58^{\mathrm{a}}$ & 0.37 & $4.46^{\mathrm{a}}$ & 0.31 & 0.39 \\
Milk protein, $\% \ldots \ldots \ldots \ldots .$. & $3.46^{\mathrm{a}}$ & 0.15 & $3.53^{\mathrm{a}}$ & 0.21 & $3.36^{\mathrm{a}}$ & 0.24 & 0.20 \\
Milk sugar, $\% \ldots \ldots \ldots \ldots \ldots$. & $4.88^{\mathrm{a}}$ & 0.13 & $4.92^{\mathrm{a}}$ & 0.12 & $4.89^{\mathrm{a}}$ & 0.04 & 0.10 \\
\hline
\end{tabular}

\section{Experiment 2}

DPM2

SBM2

UREA2

SEM

Milk yield/d

Milk yield, $\mathrm{kg}$.................. 20.6

$4 \%$ FCM, kg ................. 22. 2 a

Milk dry matter, g ......... 2672a

Milk ash, $g$................... 134a

Milk fat, $g$................. $928^{\mathrm{a}}$

Milk protein, $g$............. $651^{\mathrm{a}}$

Milk sugar, $g$.............. 1020a

$\begin{array}{rrrrrr}1.4 & 19.1^{\mathrm{a}} & 1.4 & 19.5^{\mathrm{a}} & 2.4 & 3.1 \\ 1.1 & 22.0^{\mathrm{a}} & 1.9 & 20.6^{\mathrm{a}} & 3.3 & 2.3 \\ 119 & 2613^{\mathrm{a}} & 210 & 2566^{\mathrm{a}} & 352 & 245 \\ 10 & 128^{\mathrm{a}} & 7 & 128^{\mathrm{a}} & 18 & 13 \\ 52 & 956^{\mathrm{a}} & 104 & 854^{\mathrm{a}} & 162 & 120 \\ 23 & 650^{\mathrm{a}} & 51 & 641^{\mathrm{a}} & 82 & 56 \\ 69 & 930^{\mathrm{a}} & 100 & 969^{\mathrm{a}} & 119 & 101\end{array}$

Milk composition

\begin{tabular}{|c|c|c|c|c|c|c|c|}
\hline Milk dry matter, $\%$ & $12.97^{\mathrm{a}}$ & 0.47 & $13.67^{\mathrm{a}}$ & 0.57 & $13.11^{\mathrm{a}}$ & 0.42 & 0.55 \\
\hline Milk ash, $\%$................... & $0.65^{\mathrm{a}}$ & 0.03 & $0.67 \mathrm{a}$ & 0.03 & $0.65^{\mathrm{a}}$ & 0.03 & 0.03 \\
\hline Milk fat, $\%$. ….............. & $4.52^{\mathrm{a}}$ & 0.35 & $5.02^{\mathrm{a}}$ & 0.48 & $4.36^{\mathrm{a}}$ & 0.42 & 0.48 \\
\hline Milk protein, $\%$............. & $3.16^{\mathrm{a}}$ & 0.14 & $3.42^{\mathrm{a}}$ & 0.23 & $3.30^{\mathrm{a}}$ & 0.20 & 0.21 \\
\hline Milk sugar, $\%$. .............. & $4.93^{\mathrm{a}}$ & 0.06 & $4.84^{\mathrm{a}}$ & 0.18 & $4.94^{\mathrm{a}}$ & 0.08 & 0.12 \\
\hline
\end{tabular}

Means with different letters were significantly different.

$\mathrm{a}, \mathrm{b}(\mathrm{P}<0.05)$.

Expt. 2 were $-0.81,-1.64$ and $-1.80 \%$ for DPM2, SBM2 and UREA2, respectively, but the differences were not statistically significant $(\mathrm{P}>0.05)$.

All groups had deficient energy intake during the first part of the experiment (Table 11). The percentages of the FU requirements available were on average 96.8, 96.8 and $96.1 \%$ for DPM2, SBM1 and UREA1 and 98.2, 112.3 and 106.5 $\%$ for DPM2, SBM2 and UREA2. The difference between DPM2 and SBM2 was significant $(\mathrm{P}<0.05)$. The protein supply of DPM2 was also deficient, $88.0 \%$ of requirement, and the difference between this and the other groups was significant $(\mathrm{P}<0.05)$. 

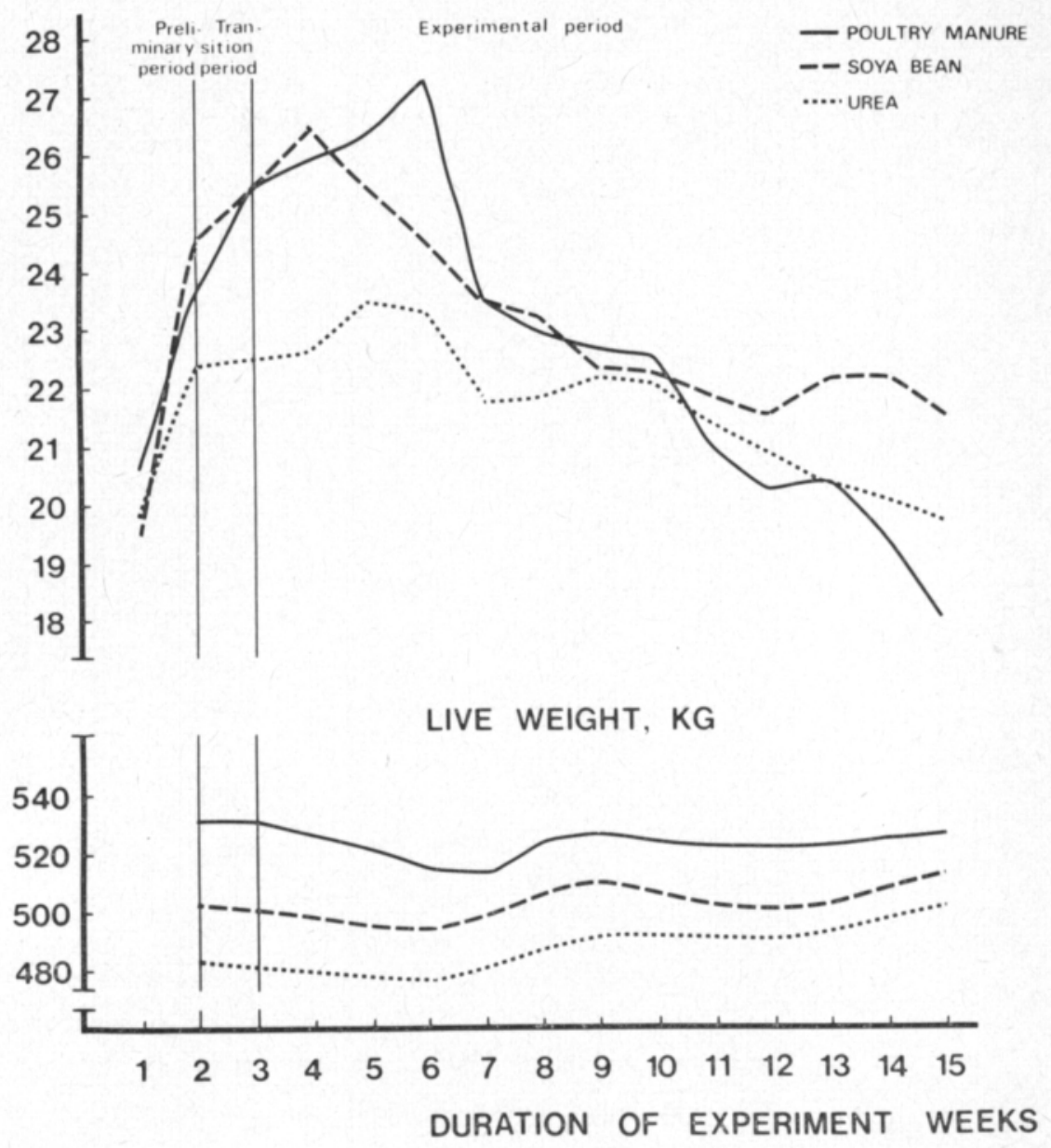

Fig. 3. Milk yield and live-weight changes of the cows in different groups. Experiment 1.

The average bodyweight changes were $-0.048,0.119,0.216 \mathrm{~kg} / \mathrm{d}$ for DPM1, SBM1 and UREA1 and $0.033,-0.017$ and $-0.056 \mathrm{~kg} / \mathrm{d}$ for DPM2, SBM2 and UREA2. The differences were not significant $(\mathrm{P}>0.05)$ (Table 11).

Feed utilisation did not differ in Expt. 1, the average FU consumption $/ \mathrm{kg}$ FCM being 0.37, but in Expt. 2 DPM2 had a smaller value, $0.39(\mathrm{P}<0.05)$, compared with the other groups $(0.45$ and 0.43$)$. Digestible crude protein utilisation varied between groups but the differences were not significant $(\mathrm{P}>0.05)$ in Expt. 1. In Expt. 2 DPM2 had a significantly smaller $(\mathrm{P}<0.05)$ value, $51.2 \mathrm{DCP} / \mathrm{kg} 4 \% \mathrm{FCM}$, compared with other groups.

The intake of nutrients cannot match the output in milk during early lactation regardless of diet composition. Dry matter intake reaches a peak only about $12-15$ weeks after calving (Broster and Alderman 1977). The 


\section{EXPERIMENT 2 MILK PRODUCTION, (4\%) KG/D}
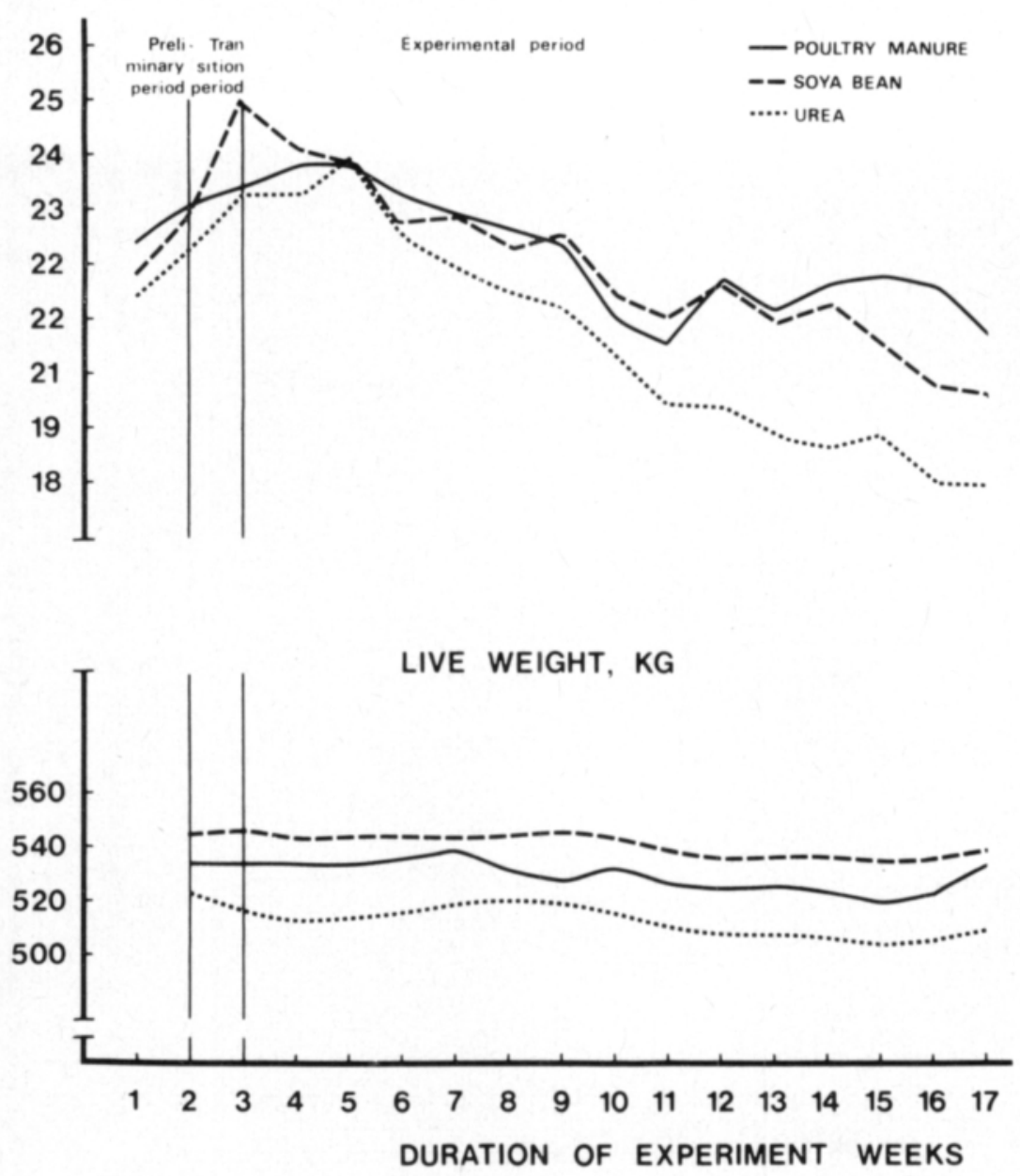

Fig. 4. Milk yield and live-weight changes of the cows in different groups. Experiment 2.

intake is affected by the liveweight, liveweight changes, and milk yield of the individual cow.

Intake is affected by diet composition (BINEs 1976). The average energy value of the DPM-concentrate was $13 \%$ lower than that of SBM or UREA, with the effect that the cows on DPM diet could not consume enough energy to meet their reguirement. The same observation was made in studies performed by Bull and Reid (1971). Thomas et al. (1972) Kneale and Garstang (1975), Silva et al. (1976), and Sмiтh et al. (1976).

The rapid decline in milk yield in early lactation may reflect a shortage of dietary protein that can not be totally compensated for by mobilizing protein from body reserves. The lactating cow can draw on body reserves only for a limited time, after which the shortage of dietary protein reduces milk production. 
Fig. 5. Chemical composition of milk in different groups, Experiment 1 .

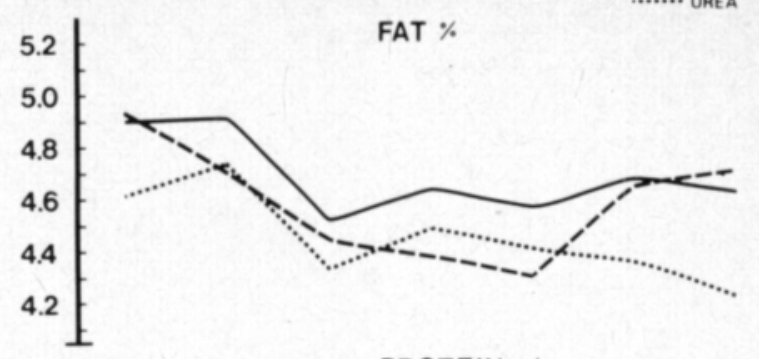

PROTEIN \%

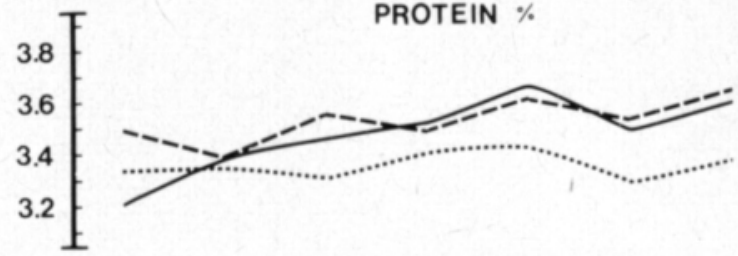

LACTOSE \%

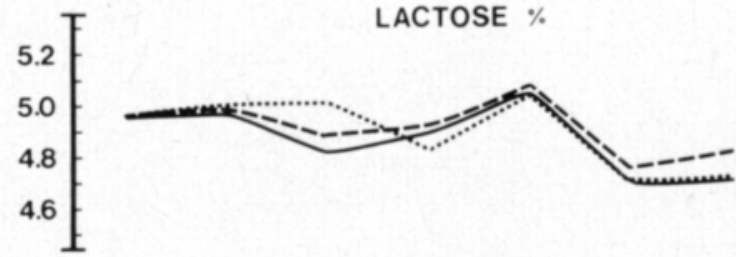

DRY MATTER \%

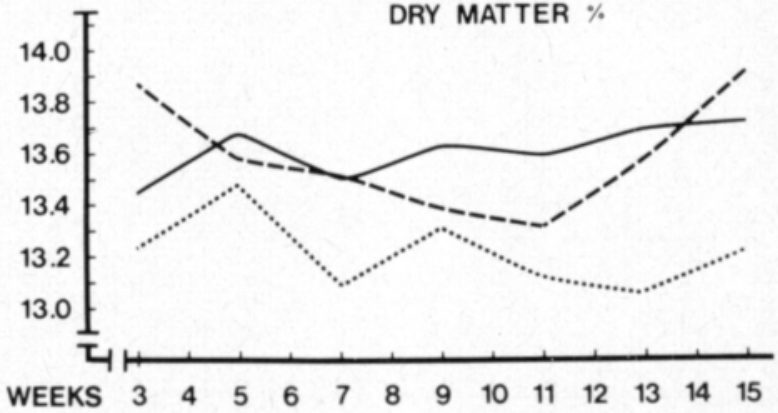

BATH et al. (1965) reported that approximately $19 \%$ of the body weight loss in lactating dairy cattle was body protein, but SATTER and Roffler (1975) suggested only $15 \%$. The sharp reduction in milk production of the cows on the DPM diet in Expt. 1 at about 7 weeks indicates that the DPM diet was not meeting the amino acid requirement of the cows over a long period and body protein reserves were being depleted. This was also indicated by the rapid decline of live weights, on average $642 \mathrm{~g} / \mathrm{cow} / \mathrm{d}$, during weeks $3-7$ and more efficient DCP utilisation in milk production, $55.1 \mathrm{~g} / \mathrm{kg}$ FCM, for DPM1. The corresponding figures for SBM1 and UREA1 were 57.6 and $\mathbf{5 8 . 8}$ g, respectively.

The peak yields of the UREA groups were $23.5 \mathrm{~kg} \mathrm{FCM} / \mathrm{d}$ in UREA1 and $24.0 \mathrm{~kg}$ in UREA2. These peaks were lower than in the other groups, especially in Expt. 1 where the peaks were 27.3 and $26.6 \mathrm{~kg} \mathrm{FCM} \mathrm{in} \mathrm{DPM1} \mathrm{and} \mathrm{SBM1,}$ respectively. However, the decline in milk production was not very rapid for the UREA groups. 


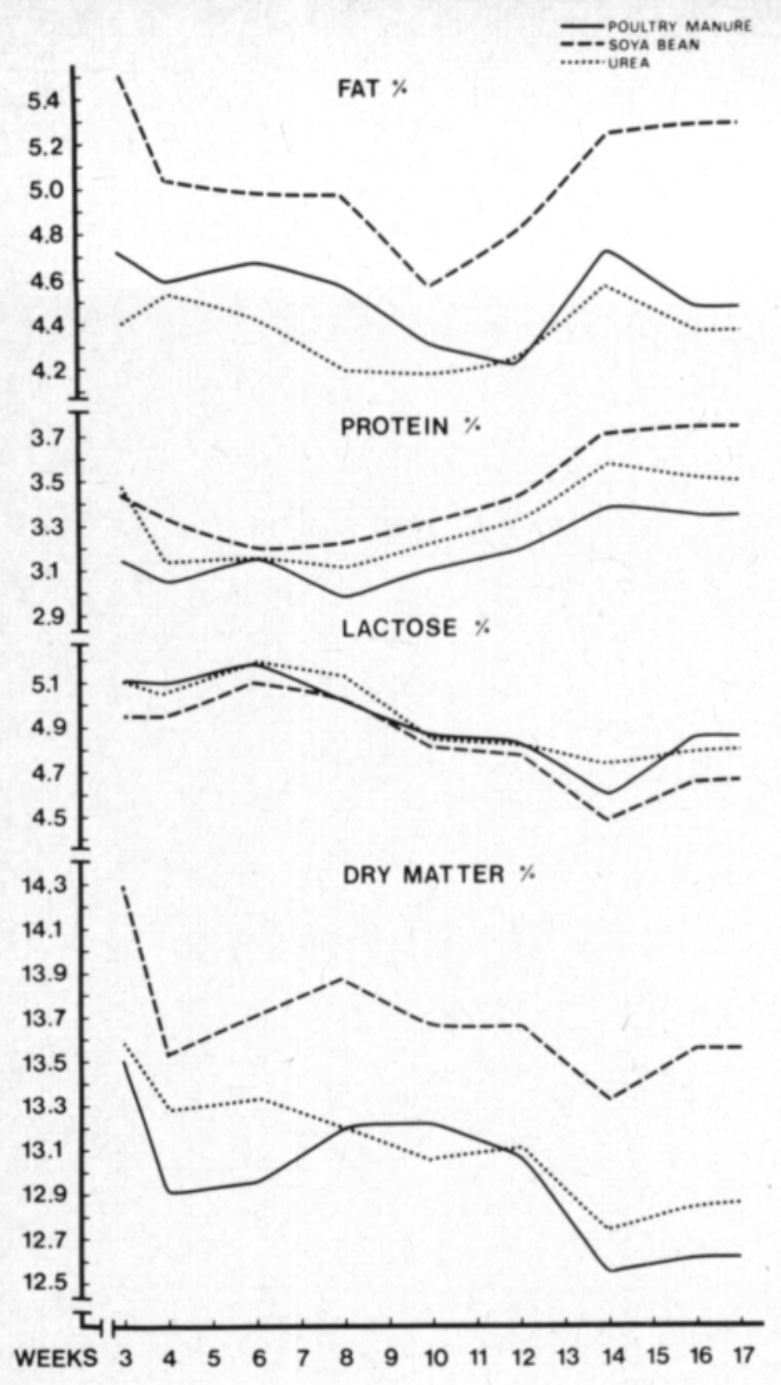

Fig. 6. Chemical composition of milk in different groups, Experiment 2.

When the diet contained only soybean meal as the supplementary nitrogen the source a greater quantity of amino acids presumably reached the lower gut of cows and more amino acids were available for synthesis of milk. Since supplying additional amino acids in the form of casein to the lower gut has improved animal performance (CLARK 1975), protecting high quality protein from microbial fermentation in the rumen and adding NPN to the diet as a source of ammonia for maximizing microbial protein synthesis may offer an alternative and more economical method of feeding high yielding dairy cows during early lactation (CHALUPA 1975). However, if the high quality protein is not protected, non protein nitrogen may have limited value in the diet of high producing dairy cows during early lactation, as the degradation of dietary plant protein in typical diets of dairy cows, especially on grass silage based diets, would supply adequate ammonia for microbial synthesis (SATter and SLYTER 1974, Satter and Roffler 1975, Wohlt et al. 1978). 
An average $200 \mathrm{~g}$ microbial protein per $\mathrm{kg}$ organic matter (OM) in synthesised in the rumen (Roffler and SAtter 1975, Hagemeister et al. 1976). Employing the net energy system used in Finland ( $\mathrm{FU}=0.7 \mathrm{~kg}$ starch) this value corresponds to $70 \mathrm{~g}$ digestible bacterial protein per $\mathrm{FU}$ if $65 \%$ of digestible organic matter (DOM) of the ration is fermented, the digestibility of bacterial protein being set at $70 \%$ and one $\mathrm{kg}$ DOM corresponding to $0.63 \mathrm{FU}$ (HAGEmeister and Kaufmann 1974, Roffler and Satter 1975, Kaufmann 1977 b, Roy et al. 1977). According to Finnish feeding standard, dairy cows require $70 \mathrm{~g} \mathrm{DCP} / \mathrm{FU}$ for maintenance, $109 \mathrm{~g}$ for a milk yield of $10 \mathrm{~kg}$ and $123 \mathrm{~g}$ for a yield of $20 \mathrm{~kg}$ daily. The maintenance requirement of digestible crude protein can be covered by bacterial protein or by an NPN source totally. When the yield of milk is $25 \mathrm{~kg}$, the cow requires totally $14.2 \mathrm{FU}$ and $1800 \mathrm{~g} \mathrm{DCP}$. Because only $1000 \mathrm{~g}$ digestible bacterial protein will be supplied, the remainder, about $45 \%$ of the requirement, will have to be supplied by undegraded dietary protein or from body reserves. From these figures it follows that a level of $100 \mathrm{~g} \mathrm{DCP}$ per FU is the maximum which will supply usable nitrogen from an NPN supply.

The calculated DCP concentration in the diets without protein supplement was on average $103 \mathrm{~g} / \mathrm{FU}$ in Expt. 1 and $96 \mathrm{~g} / \mathrm{FU}$ in Expt. 2. The protein provided by DPM was 29.0 and $19.0 \%$ of the DCP supply in diets DPM1 and DPM2, respectively. The average uric acid intake was $186 \mathrm{~g}$ and $24 \mathrm{~g} / \mathrm{d}$. The corresponding values for urea were $17.5 \%$ and $18.4 \%$ and the average urea intake was $140 \mathrm{~g} / \mathrm{d}$. The basal ration, consisting only of hay and grain concentrate might satisfy the DCP requirement of a milk production of about $5-10 \mathrm{~kg}$. In this study milk production obviously responded well to DPM and urea supplementation. The energy supply of the total FU-intake from concentrate was 74 and $73 \%$ in Expts. 1 and 2, respectively, and in these cases microbial synthesis from non protein nitrogen seems to be efficient owing the high amount of available energy from starch. SATTER and Roffler (1975) and Burroughs et al. (1975) have shown a strong dependence of microbial use of NPN on the energy content of diet. In addition, the microbial protein production is affected by the solubility of the dietary protein, its degradation by rumen microbes, the content of protein in the ration, the source of energy and the level of milk yield.

The literature suggests, that feeding of NPN is efficient only for milk yields up to $15 \mathrm{~kg}$ daily. This is in good agreement with results for cows fed purified diets where urea was the only of nitrogen (VIRTANEN 1966) and with results of feeding trials carried out by Helmer and BARTLEy (1971), Huber et al. (1972) and Møller (1973).

Kaufmann and Hagemeister (1975) concluded on the basis of 45 reported studies that partial use of NPN can be justified where $80 \%$ or less of the protein requirement is met from natural protein for cows producing $20 \mathrm{~kg}$ milk/d. Drops in the milk yield when NPN was used were reported by RoFFLER and SATtER (1975) in a literature study. The results of studies by MøLlER and Neiman-Sørensen (1977), however, showed no decrease in milk yield of 20 $\mathrm{kg} \mathrm{FCM}$ if urea was substituted for about $20 \%$ of the total in the ration. These findings are in good agreement with the results obtained in present study. 


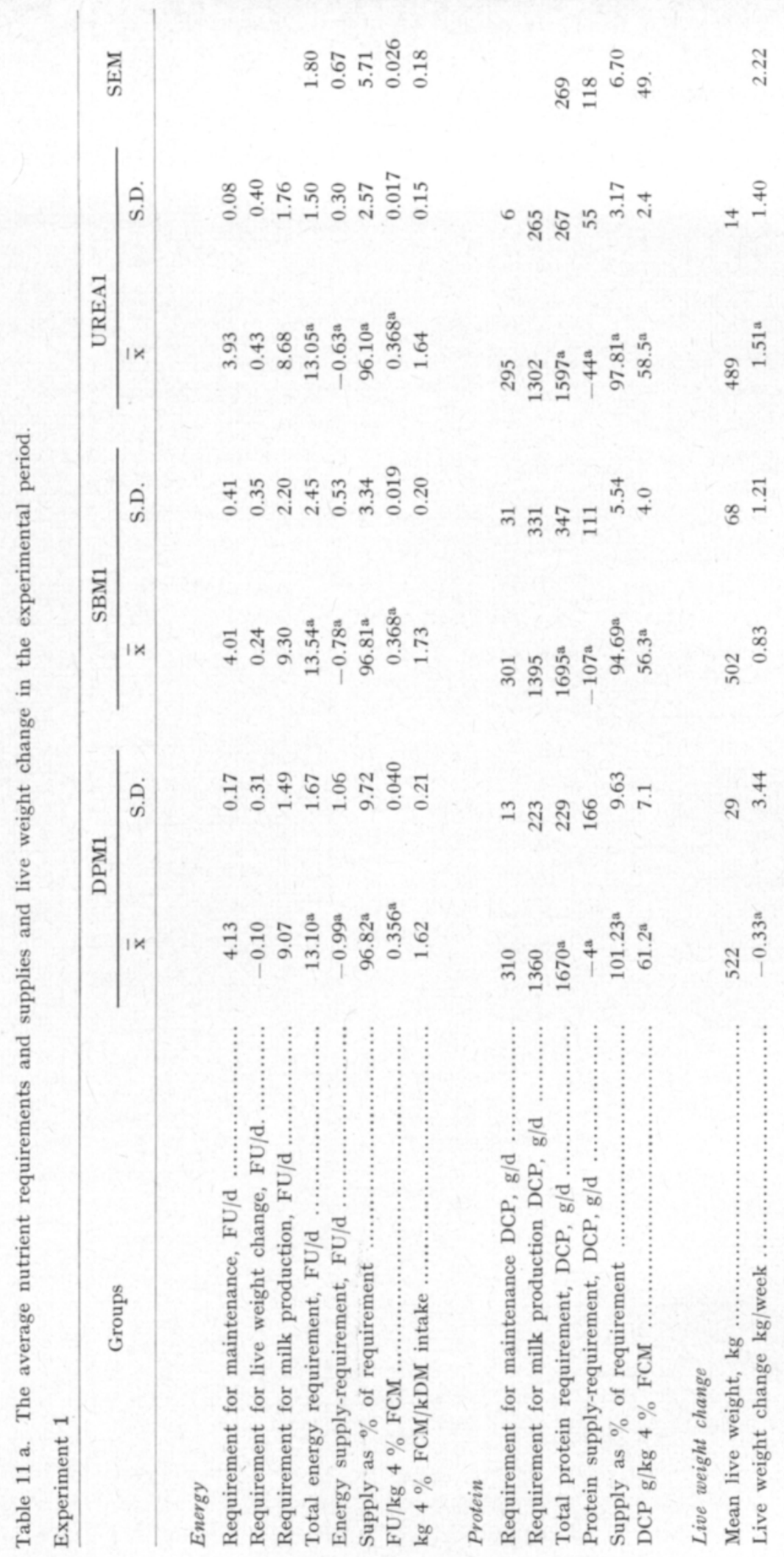




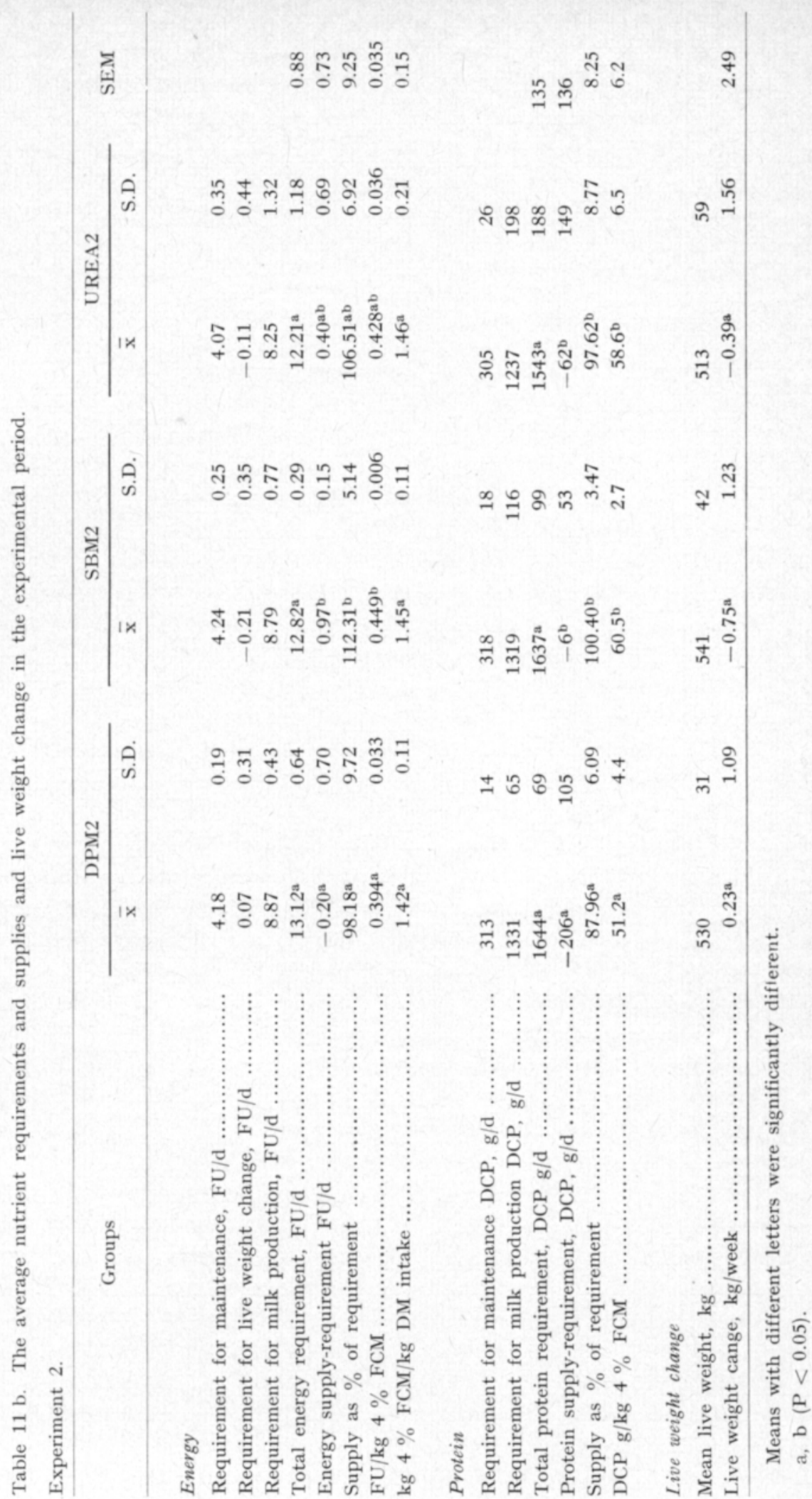


The maximum level of dietary crude protein at which cows will respond to NPN supplementation is still somewhat controversial. ROFFLER and SATTER (1975), Kaufmann (1977 a) and Satter and Roffler (1977 a) showed the ineffectiveness of NPN in dairy ration containing more than 12 to $13 \%$ crude protein in dry matter. Yet the data of Jones et al. (1975) showed a response to NPN when crude protein complete rations were raised from 14.5 to $15.8 \%$ with NPN. In present study the crude protein level was on average $14.2 \%$ in DM.

\section{2. Blood metabolic profile}

The effect of different protein supplements on the hematological and blood chemical data are given in Table 12 and Figures 7-12. In Table 13 are presented the corresponding data from two cows fed different amounts of poultry manure and in Table 14 are the values at different sampling times after feeding.

Hemoglobin was higher $(\mathrm{P}<0.05)$ in DPM1 than in the other groups, while PCV \% was higher $(\mathrm{P}<0.05)$ in SBM2. The plasma glucose of DPM1 was significantly $(\mathrm{P}<0.01)$ lower than that of SBM1 and lower than that UREA1 $(\mathrm{P}<0.05)$. In Experiment 2 the plasma glucose concentration was again higher in the SBM2 groups than in the others but the difference was not statistically significant. Plasma glucose increased $(\mathrm{P}<0.05)$ with an increase in the DPM supplement, 0 to $40 \%$ in concentrate mixture. Also plasma glucose increased significantly after feeding $(\mathrm{P}<0.05)$. The energy deficiency of cows receiving poultry manure reflected the lower plasma glucose concentration.

Plasma urea-N was significantly $(\mathrm{P}<0.01)$ higher in UREA1 and UREA2 groups than in other groups and higher $(\mathrm{P}<0.01)$ in DPM1 than in SBM1, but lower $(\mathrm{P}<0.01)$ in DPM2 than in SBM2. Plasma urea-N increased $(\mathrm{P}<$ 0.05) with an increase in the DPM supplement in concentrate mixture, but neither effect was consistently linear. Plasma urea- $\mathrm{N}$ increased rapidly after feeding and then decreased, and the plasma urea- $\mathrm{N}$ value $\mathbf{5 . 5}$ hours after feeding was statistically lower $(\mathrm{P}<0.05)$ than at 2.5 hours. Also the plasma urea-N increased significantly $(\mathrm{P}<0.01)$ during the feeding experiments with respect to days after calving the correlation coefficients being .333 and .418 in the Expts 1. and 2. respectively. The plasma urea-N was likewise correlated to the urea intake $(.365$ and $.354 ; \mathrm{P}<0.01)$ and to the percentage of supply minus requirement of digestible crude protein (.239 and .490; $\mathrm{P}<$ 0.01 ). There was no correlation between plasma urea-N and intake of DCP. Urea nitrogen in blood, produced by conversion of absorbed ammonia to urea by the liver was shown by LEwIS (1957) to be a sensitive indicator of changes in the rumen ammonia concentration. Plasma urea-N was higher of cows receiving DPM compared to SBM, and also the rumen ammonia-N was higher on the DPM diets. This agrees with the results of CASwELL et al. (1978), they found the blood urea levels were within the normal range and followed the same general trend as ruminal fluid ammonia nitrogen levels, but were not significantly different among treatments with different amount of poultry litter. The blood urea- $\mathrm{N}$ of lactating cows has also been directly related to the intake of dietary protein (MAnston et al. 1975, TrEacher et al. 1976). In general, 
urea diets result in greater blood urea- $\mathrm{N}$ than do isonitrogenous plant protein diets (Huber 1975, Kwan et al. 1977). Plasma urea-N was not so high with DPM as with urea feeding because the uric acid, the major NPN fraction in DPM is less soluble and more slowly available to rumen bacteria than urea and hence the passage of ammonia direct throught the rumen wall is less. SмrтH et al. (1978 b) also observed lower plasma urea-N values in calves fed DPM diets compared with urea, but higher than with soybean meal feeding. They found the peak in plasma urea-N concentration to occur 2 hours post feeding, after which it rapidly decreased, which agrees with the results found in this study.

Table 12. Hematological and blood chemical data from cows (mean \pm S.D.).

\begin{tabular}{lrrrrrrr}
\hline Groups & & DPM1 & & \multicolumn{2}{c}{ SBM1 } & & UREA1 \\
Experiment $\underline{1}$ & $\overline{\mathrm{x}}$ & S.D. & $\overline{\mathrm{x}}$ & S.D. & $\overline{\mathrm{x}}$ & S.D. \\
\hline
\end{tabular}

n

42

35

42

Hemoglobin, g/1 $10.3 \quad 98.1^{\mathrm{a}}$

$8.6 \quad 98.8^{\mathrm{a}}$

8.5

PCV, \% $100.2^{\mathrm{b}}$

10.3

$32.3^{\mathrm{a}}$

$2.6 \quad 33.0^{\mathrm{a}}$

2.8

Plasma glucose, mmol/1 .............. 2.50ae

Plasma urea-N, mmol/1 .............. 2.93e

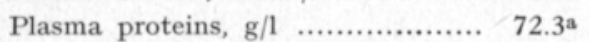

Plasma uric-acid, $\mu \mathrm{mol} / 1$............ $50^{\mathrm{a}}$

Inorg. phosphorus, mmol/1 ......... $1.73^{\mathrm{b}}$

Calcium, mmol $/ 1$....................... $1.86^{\mathrm{a}}$

$0.39 \quad 2.59^{\mathrm{bt}}$

0.39

$2.57^{\mathrm{b}}$

0.32

0.55

$2.55^{\mathrm{d}}$

0.93

$3.59^{t}$

1.32

$9.3 \quad 69.0^{\mathrm{a}}$

11

0.33

$45^{\mathrm{a}}$

0.21

$1.52^{\mathrm{a}}$

9.9

$68.8^{\mathrm{a}}$

8.4

Magnesium, mmol/1 .

$0.80^{\mathrm{a}}$

Sodium, mmol/1

$115.5^{\mathrm{ab}}$

0.10

$1.78^{\mathrm{a}}$

6

$43^{\mathrm{a}}$

8

Potassium, mmol/1 ................... 4.37 bde

$19.6 \quad 112.7^{\mathrm{ad}}$

Iron, $\mu \mathrm{mol} / 1$

$30.8^{\text {be }}$

0.52

$0.74^{\mathrm{a}}$

0.37

$1.68^{\mathrm{ab}}$

0.23

Copper, $\mu \mathrm{mol} / 1$

$12.7 \quad 25.9^{\mathrm{ad}}$

$4.1 \quad 11.2^{\mathrm{a}}$

0.31

$1.88^{\mathrm{a}}$

0.38

Zinc, $\mu \mathrm{mol} / 1$

$11.4^{\mathrm{b}}$

$6.3 \quad 12.0^{\mathrm{e}}$

0.16

$0.78^{\mathrm{a}}$

0.10

$20.2 \quad 122.5^{e}$

22.3

$0.62 \quad 4.44^{\mathrm{ee}}$

0.50

$8.6 \quad 28.5^{\text {bde }}$

8.9

2.2. $11.1^{\mathrm{a}}$

2.0

$11.1 \quad 13.4^{\mathrm{f}}$

10.4

n

Hemoglobin, g/1 ...................... 103.9a

PCV, $\%$................................ $34.3^{\mathrm{a}}$

Plasma glucose, mmol/1 .............. $3.23^{\mathrm{a}}$

Plasma urea $\mathrm{N}, \mathrm{mmol} / 1$.............. $3.10^{\mathrm{d}}$

Plasma proteins, $g / 1 \quad \ldots \ldots \ldots \ldots \ldots \ldots . . . .75 .3^{\mathrm{a}}$

Plasma uric acid, $\mu \mathrm{mol} / 1 \ldots \ldots \ldots \ldots .44^{\mathrm{b}}$

Inorg. phosphorus, mmol/1 ......... $1.88^{\mathrm{b}}$

Calcium, mmol $/ 1$...................... $1.92^{\mathrm{ab}}$

Magnesium, mmol ..................... $0.91^{\mathrm{ad}}$

Sodium, $\mathrm{mmol} / 1$ $138.8^{\mathrm{a}}$

Potassium, mmol/1 .................... 4.28 be

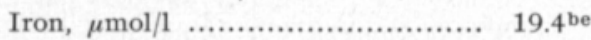

Copper, $\mu \mathrm{mol} / 1$.......................... 10.9 $19^{\text {bde }}$

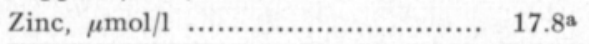

48

40

40

\begin{tabular}{ccccc}
10.8 & $109.9^{\mathrm{a}}$ & 6.5 & $103.2^{\mathrm{a}}$ & 12.0 \\
3.6 & $36.4^{\mathrm{b}}$ & 2.2 & $33.7^{\mathrm{a}}$ & 3.6 \\
0.36 & $3.37^{\mathrm{a}}$ & 0.56 & $3.22^{\mathrm{a}}$ & 0.49 \\
0.87 & $3.62^{\mathrm{e}}$ & 0.93 & $5.14^{\mathrm{f}}$ & 1.25 \\
6.4 & $76.3^{\mathrm{a}}$ & 5.6 & $74.2^{\mathrm{a}}$ & 8.0 \\
9 & $43^{\mathrm{a}}$ & 9 & $44^{\mathrm{b}}$ & 5 \\
0.41 & $1.64^{\mathrm{a}}$ & 0.31 & $1.65^{\mathrm{a}}$ & 0.27 \\
0.27 & $2.00^{\mathrm{be}}$ & 0.23 & $1.84^{\mathrm{ad}}$ & 0.24 \\
0.13 & $0.97^{\mathrm{be}}$ & 0.11 & $0.94^{\mathrm{abde}}$ & 0.12 \\
6.5 & $137.9^{\mathrm{a}}$ & 6.1 & $142.2^{\mathrm{a}}$ & 10.9 \\
0.55 & $4.12^{\mathrm{ab}}$ & 0.53 & $3.99^{\mathrm{ad}}$ & 0.44 \\
4.8 & $16.8^{\mathrm{abde}}$ & 4.2 & $15.3^{\mathrm{ad}}$ & 3.9 \\
1.8 & $11.8^{\mathrm{be}}$ & 1.6 & $10.6^{\mathrm{ad}}$ & 1.7 \\
9.1 & $21.4^{\mathrm{ab}}$ & 14.7 & $22.6^{\mathrm{b}}$ & 20.0 \\
\hline
\end{tabular}

Means with different letters were significantly different.

a, b, c $(\mathrm{P}<0.05)$; d, e, f $(\mathrm{P}<0.01)$ 

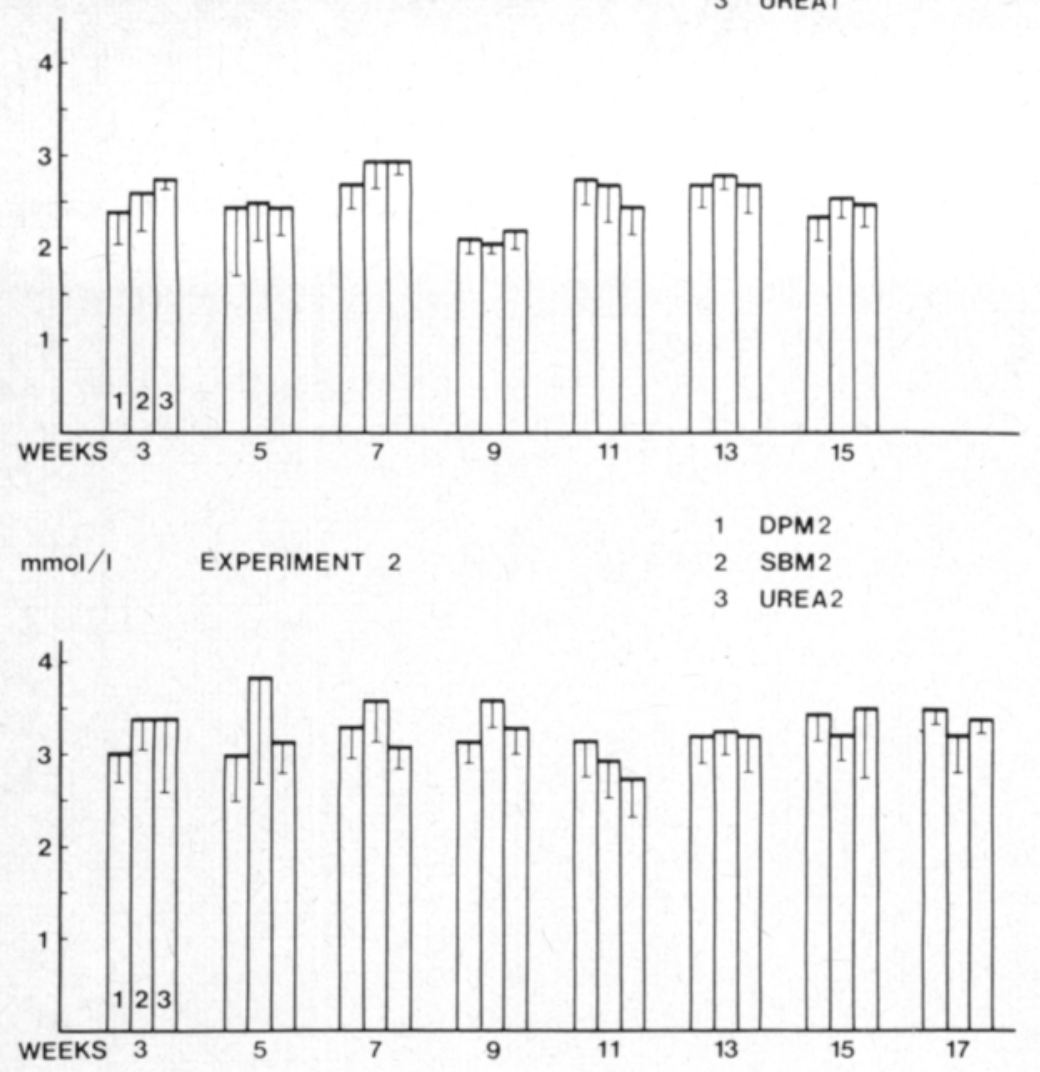

Fig. 7. Plasma glucose concentration during experimental period.
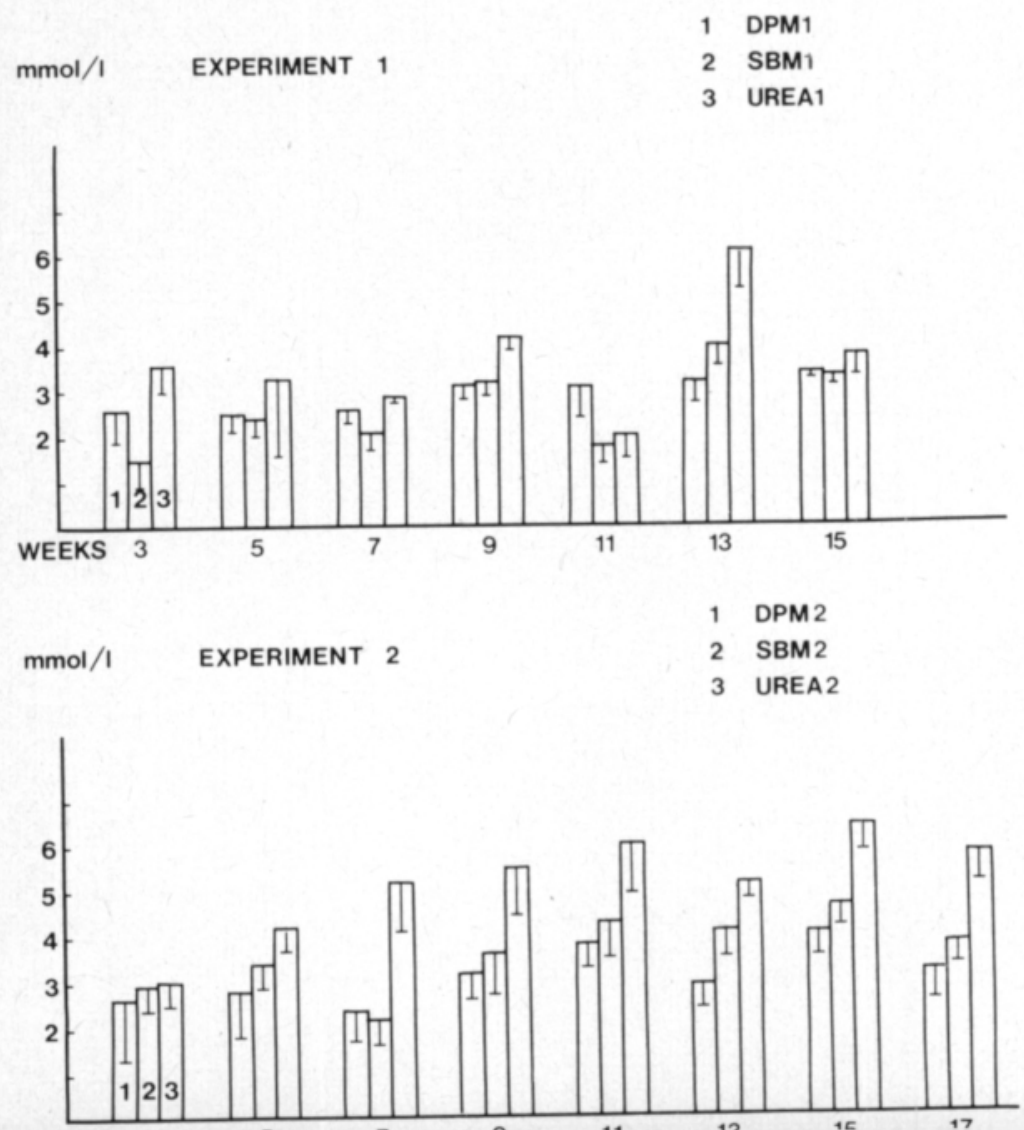

Fig. 8. Plasma urea-N concentration during experimental period. 


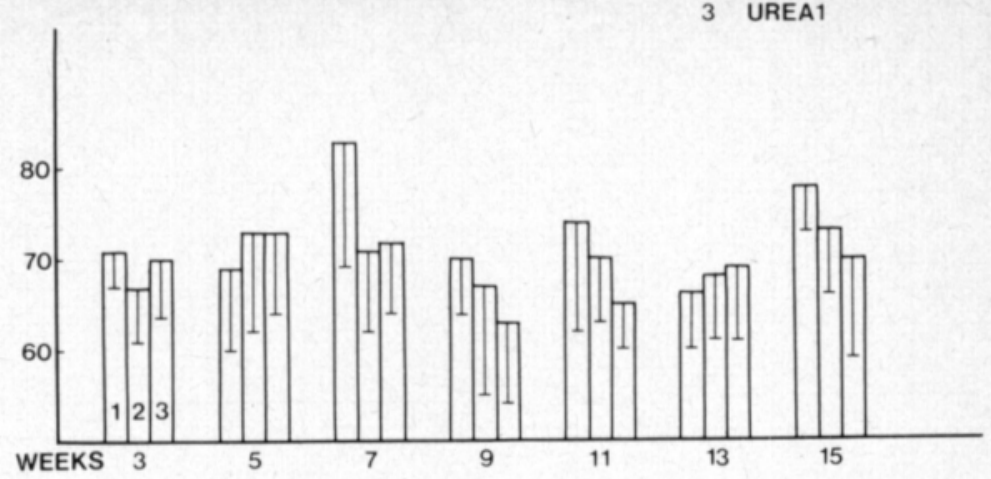

Fig. 9. Concentration of plasma proteins during experimental period.
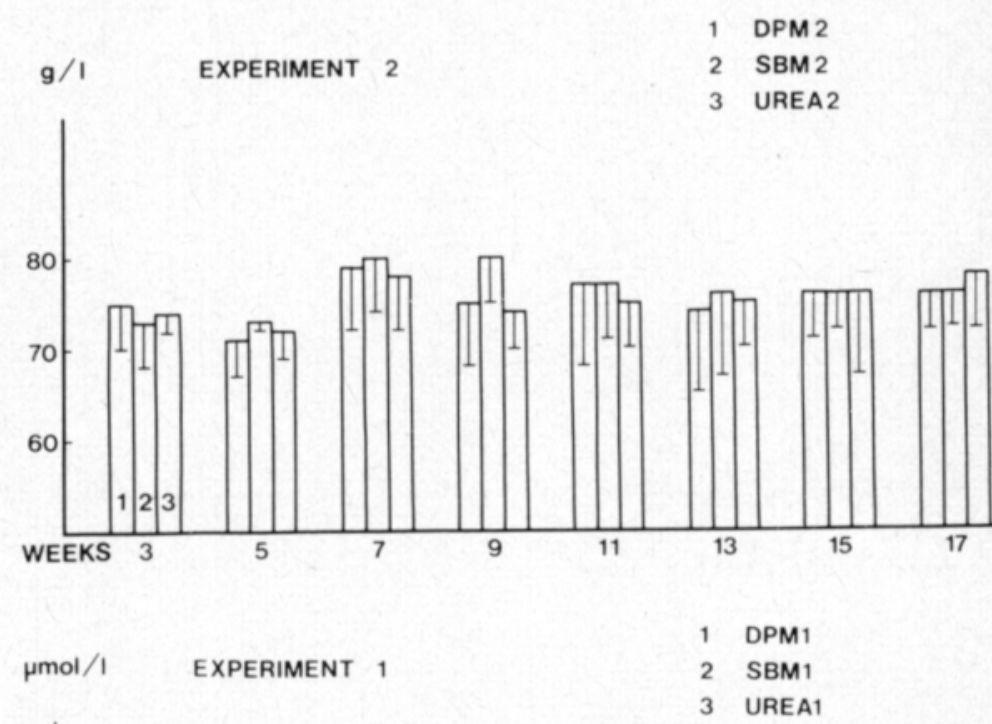

Fig. 10. Plasma uric acid concentration during experimental period.

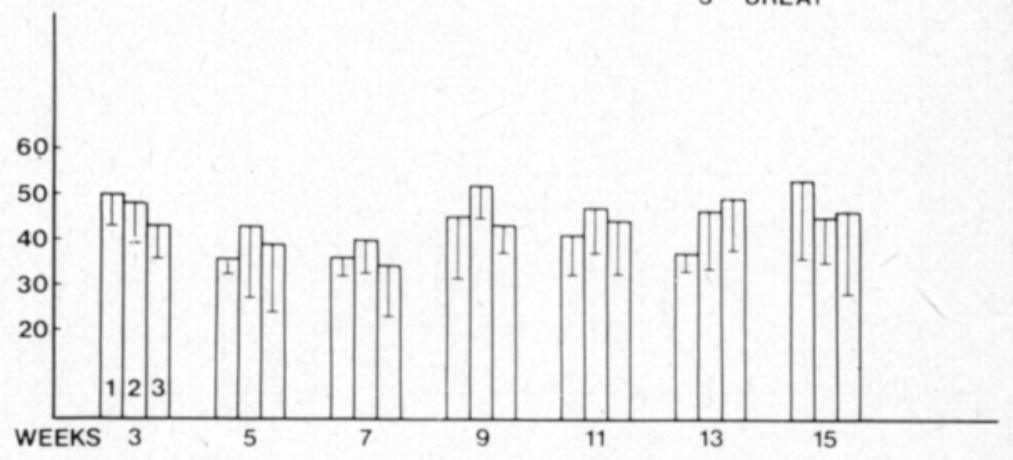



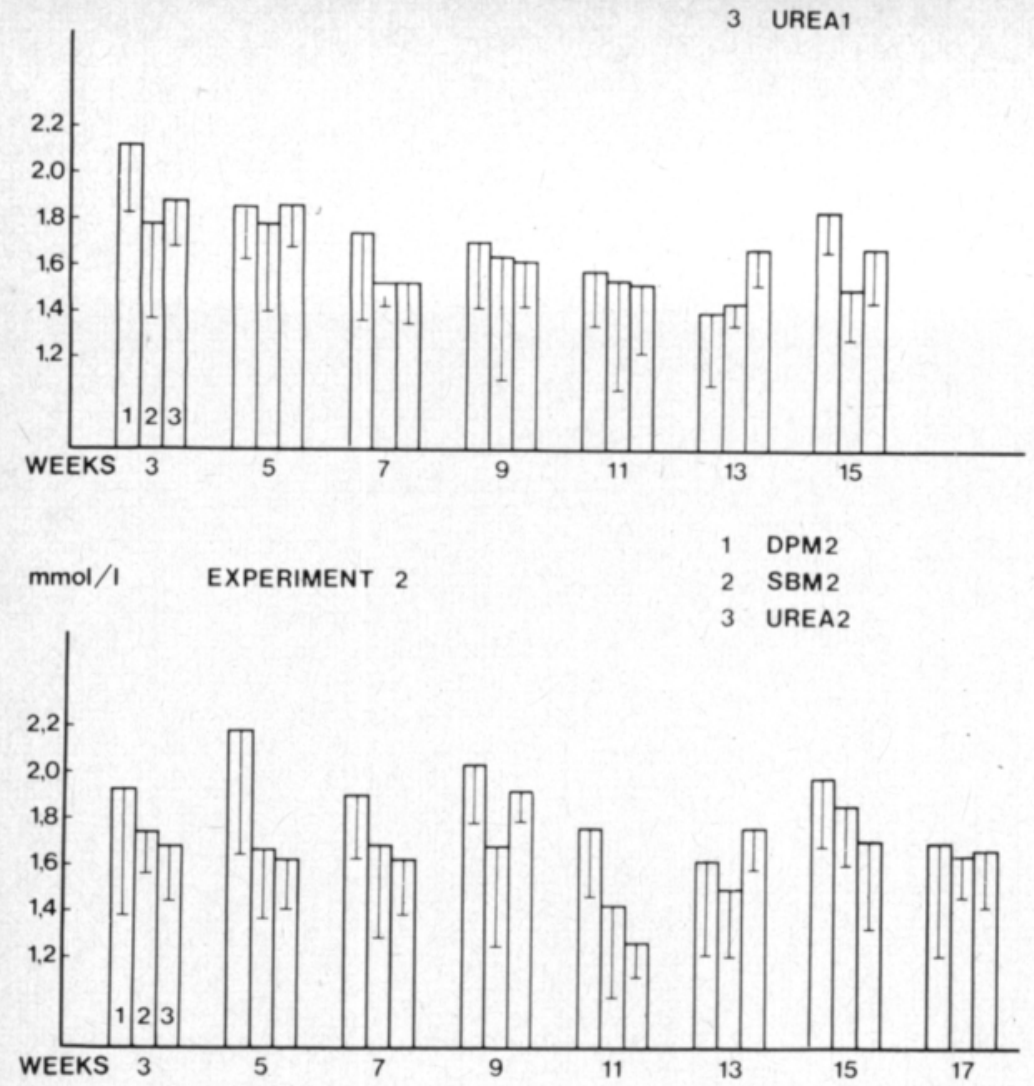

Fig. 11. Plasma inorganic phosphorus concentration during experimental period.
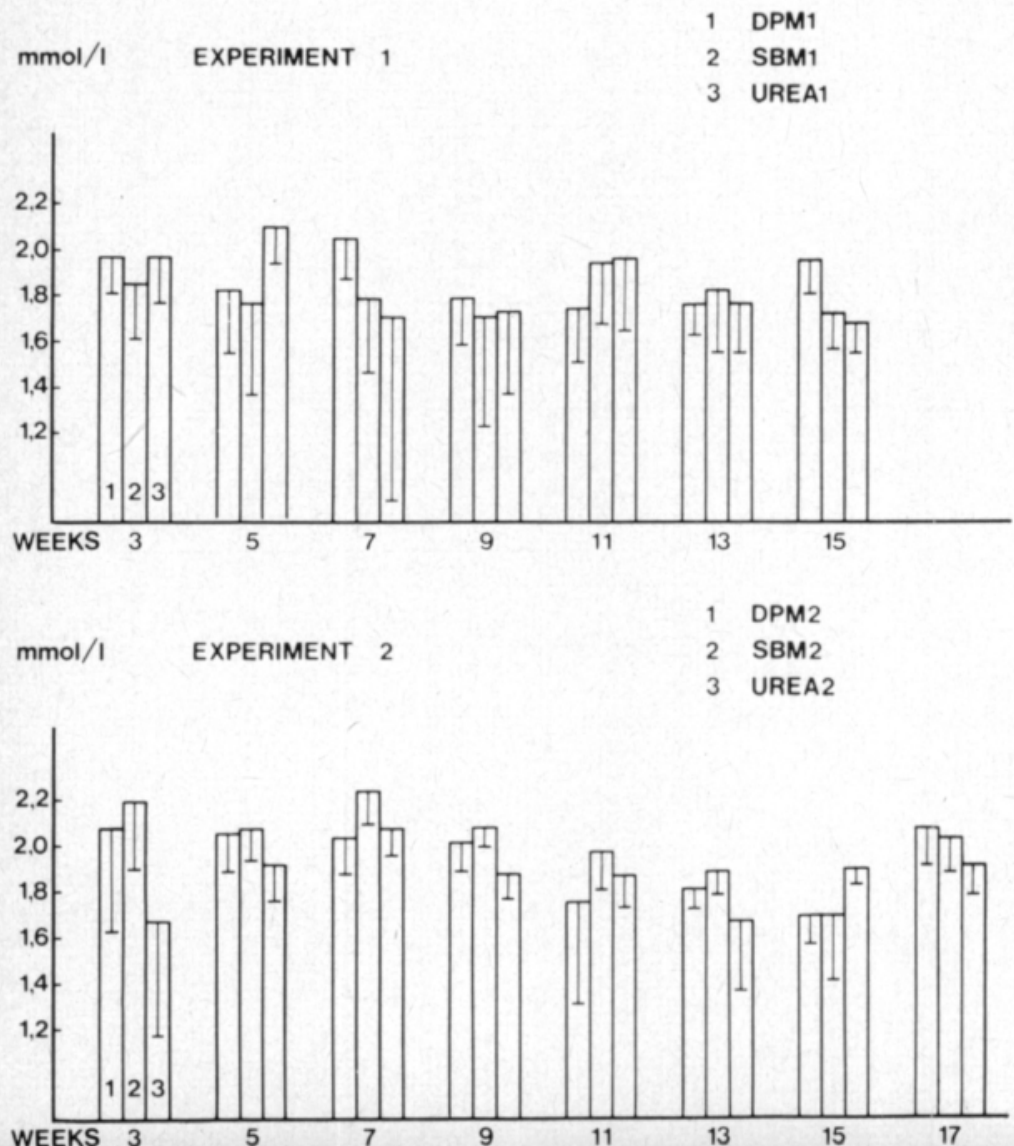

Fig. 12. Plasma calcium concentration during experimental period. 


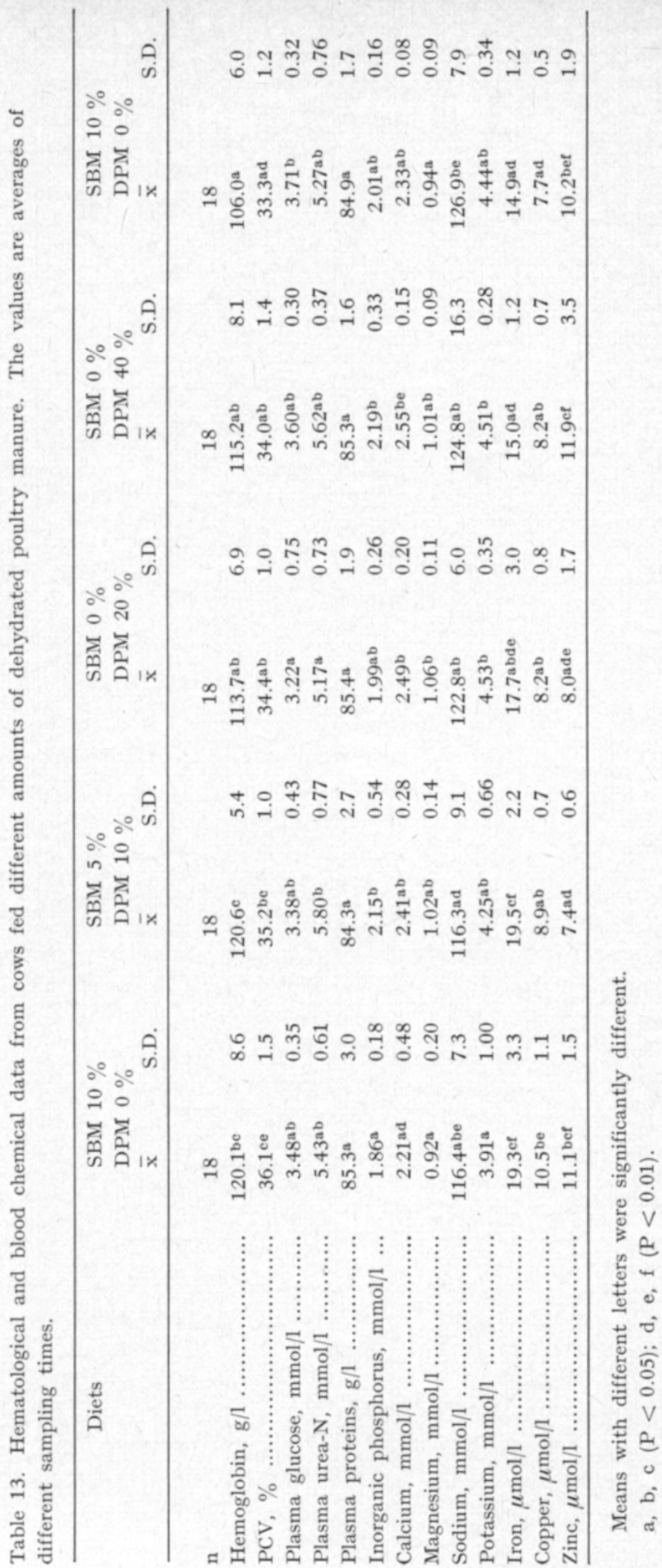


Table 14. Hematological and blood chemical data from cows fed different amounts poultry manure; the average values at different sampling times.

\begin{tabular}{|c|c|c|c|c|c|c|}
\hline & \multicolumn{2}{|c|}{$\begin{array}{c}0.5 \mathrm{~h} \text { after } \\
\text { feeding }\end{array}$} & \multicolumn{2}{|c|}{$\begin{array}{l}2.5 \mathrm{~h} \text { after } \\
\text { feeding }\end{array}$} & \multicolumn{2}{|c|}{$\begin{array}{l}5.5 \mathrm{~h} \text { after } \\
\text { feeding }\end{array}$} \\
\hline & $\bar{x}$ & S.D. & $\overline{\mathbf{x}}$ & S.D. & $\bar{x}$ & S.D. \\
\hline $\mathrm{n}$ & 30 & & 30 & & 30 & \\
\hline Hemoglobin, $g / 1$.......... & $116.3^{\mathrm{a}}$ & 9.3 & $113.8^{\mathrm{a}}$ & 9.0 & $115.3^{\mathrm{a}}$ & 8.7 \\
\hline PCV,$\%$ & $34.7^{\mathrm{a}}$ & 1.9 & $34.4^{\mathrm{a}}$ & 1.3 & $34.7 \mathrm{a}$ & 0.03 \\
\hline Plasma glucose, $\mathrm{mmol} / 1$............... & $3.44^{\mathrm{a}}$ & 0.42 & $3.38^{\mathrm{a}}$ & 0.44 & $3.61^{\mathrm{b}}$ & 0.56 \\
\hline Plasma urea-N, $\mathrm{mmol} / 1$.............. & $5.55^{\mathrm{ab}}$ & 0.61 & $5.72^{\mathrm{b}}$ & 0.66 & $5.22^{\mathrm{a}}$ & 0.70 \\
\hline Plasma proteins, $g / 1$..................... & $85.4^{\mathrm{a}}$ & 2.2 & $84.9^{\mathrm{a}}$ & 2.3 & $84.8^{\mathrm{a}}$ & 2.1 \\
\hline Inorganic phosphorus, mmol/1 $\ldots \ldots \ldots$ & $2.09^{\mathrm{a}}$ & 0.31 & $2.06^{\mathrm{a}}$ & 0.38 & $1.95^{\mathrm{a}}$ & 0.30 \\
\hline Calsium, mmol/1 .......................... & $2.38^{\mathrm{a}}$ & 0.31 & $2.39^{\mathrm{a}}$ & 0.22 & $2.41^{\mathrm{a}}$ & 0.35 \\
\hline Magnesium, mmol/1 .................... & $0.99^{\mathrm{a}}$ & 0.15 & $0.99^{\mathrm{a}}$ & 0.13 & $0.98^{\mathrm{a}}$ & 0.16 \\
\hline Sodium, $\mathrm{mmol} / 1$............................ & $121.3^{\mathrm{a}}$ & 11.5 & $122.9^{\mathrm{a}}$ & 7.7 & $120.1^{\mathrm{a}}$ & 12.8 \\
\hline Potassium, mmol/1 …................. & $4.10^{\mathrm{a}}$ & 0.58 & $4.39^{\mathrm{b}}$ & 0.48 & $4.47^{b}$ & 0.75 \\
\hline Iron, $\mu \mathrm{mol} / 1$ & $16.8^{\mathrm{a}}$ & 4.0 & $17.6^{\mathrm{a}}$ & 3.3 & $16.9^{\mathrm{a}}$ & 3.1 \\
\hline Copper, $\mu \mathrm{mol} / 1$.......................... & $8.6^{\mathrm{a}}$ & 1.4 & $8.8^{\mathrm{a}}$ & 1.2 & $8.7^{\mathrm{a}}$ & 1.2 \\
\hline Zinc, $\mu \mathrm{mol} / 1$............................ & $9.8^{\mathrm{a}}$ & 3.3 & $9.9^{\mathrm{a}}$ & 2.4 & $9.6^{\mathrm{a}}$ & 2.3 \\
\hline
\end{tabular}

Means with different letters were significantly different.

a, b $(\mathrm{P}<0.05)$

Plasma uric acid was higher in DPM groups but only the difference between DPM2 and SBM2 was statistically significant $(\mathrm{P}<0.05)$. Uric acid values of cows receiving poultry manure in the diet were in normal ranges as reported by LAIRD (1972); $0.0-2.8 \mathrm{mg} / 100 \mathrm{ml}$ and Durst et al. (1978); $0.7 \mathrm{mg} / 100 \mathrm{ml}$ plasma. Uric acid is decomposed in the rumen by microbes to ammonia and direct passage of uric acid through the rumen wall to blood is low when cows are eaten large amounts of uric acid in DPM.

The values of plasma proteins did not differ significantly among the groups but in the UREA groups the values were lowest. The inclusion rate of DPM did not have any effect on the concentration of plasma proteins. The values were quite like on different sampling times. Blood proteins have been related to nitrogen intake (Unshelm 1969, PAyne et al. 1970). Total protein in plasma is composed of albumin and globulins (SwEnson 1970). Albumin serves as the major amino acid pool (Drmopoullos 1970) and reflects the adequacy of the amino acid supply relative to demand and to some extent protein in the diet (Smith and Vandersall 1973). Manston et al. (1975) observed an increase in serum albumin in cows fed medium protein but a decrease in cows fed low protein diets. LiTTLE (1974) claimed that intake had no effect on serum albumin, but increases with increasing dietary protein have been observed by others (MAnston et al. 1975, Treacher et al. 1976). PAYne et al. (1970) concluded that albumin level is a far more important indicator of the metabolic condition than total protein or globulin.

Inorganic phosporus of the plasma was higher $(\mathrm{P}<0.05)$ in DPM1 and DPM2 than in other groups. The differences in other plasma minerals between groups were not significant. Plasma inorganic phosphorus increased $(\mathrm{P}<0.05)$, whereas magnesium $(\mathrm{P}<0.05)$ potassium $(\mathrm{P}<0.05)$ and zinc 
$(\mathrm{P}<0.05)$ decreased with increase in the amount of DPM in concentrate mixture, 0 to $40 \%$. Potassium levels increased after feeding $(\mathrm{P}<0.05)$, but other blood parameters were approximately constant throughout the sampling times (Table 14). The effect of lactation and diet upon blood electrolytes have not been established clearly. Some electrolytes vary with age, herd, breed, stress, diurnal effects and physiological stage (Rowlands and Manston 1976, AdAms et al. 1978, LEE et al. 1978). Poultry manure contains large amounts of various minerals and trace elements and the supply of those elements in the DPM diets was greater than in other diets (Table 8) even though the mineral supplement in the DPM diet was only half that in the others. The solubility of minerals in DPM has been reported to bee good (BULL and REID 1971. McNAB et al. 1974, NÄsI 1976).

The following correlation coefficients were found between milk production and blood parameters in Expt. 1: hemoglobin $-.269(\mathrm{P}<0.01), \mathrm{PCV}-.347$ $(\mathrm{P}<0.001)$, plasma glucose $-.243(\mathrm{P}<0.01)$, plasma urea- $\mathrm{N}-.214(\mathrm{P}<0.01)$, plasma proteins $-.263(\mathrm{P}<0.01)$, uric acid $-.148(\mathrm{P}>0.05)$ and plasma calcium $-.242(\mathrm{P}<0.01)$ and in Expt. $2 .:$ hemoglobin $-.234(\mathrm{P}<0.01)$, $\mathrm{PCV}-.347(\mathrm{P}<0.001)$, plasma glucose $-.256(\mathrm{P}<0.01)$, plasma urea-N $-.249(\mathrm{P}<0.01)$ plasma proteins $-.276(\mathrm{P}<0.01)$, uric acid $-.132(\mathrm{P}>$ $0.05)$ and plasma calcium $-.242(\mathrm{P}<0.01)$.

The values obtained in hematological and chemical analyses of the blood samples were within the normal range (PAYNe et al. 1970, Hewet 1974, Belyea et al. 1975, Rowlands et al. 1975, Treacher et al. 1976) and the biological significance of statistical differences is therefore difficult to assess. Blood metabolites respond to various conditions varying with age, diurnal effects and physiological stage (ADAms et al. 1978, LEE et al. 1978).

Feeding different amounts of broiler litter was not found to have a consistent effect on blood ammonia, blood urea, total red cell numbers and total and differential white cell numbers in sheep or ewes but a slight copper toxity was observed in some ewes (Fontenot et al. 1970, Fontenot et al. 1971, a WEBB et al. 1973).

From the values of the various metabolic parameters obtained in this study can be concluded that dried poultry manure in moderate amounts used as feed for dairy cows has no detrimental effect on the health or the metabolism of the animals.

\section{3. Rumen fermentation}

The average chemical compositions of the feeds used in the metabolism trials are given in Table 15, together with the calculated energy and digestible crude protein values.

The consumption of different feedstuffs and supplies of nutrients are presented in Table 16.

Rumen fluid $\mathrm{pH}$, rumen ammonia nitrogen $\left(\mathrm{NH}_{3}-\mathrm{N}\right)$ concentrations and total volatile fatty acid (VFA) production, molar percentages of various volatile fatty acids, and ratios of acetic, propionic and buturic acids are presented in Tables 17 and 18 and in Figures 13 and 14, respectively. The rumen samples 
Table 15. Compostion of feeds and calculated feed values.

\begin{tabular}{|c|c|c|c|c|c|c|c|c|c|c|}
\hline & \multirow{2}{*}{$\begin{array}{c}\text { Dry } \\
\text { matter, } \\
\%\end{array}$} & \multicolumn{3}{|c|}{$\%$ in dry matter } & \multirow[b]{2}{*}{$\begin{array}{l}\text { Crude } \\
\text { fibre }\end{array}$} & \multirow{2}{*}{$\frac{1 .}{\mathrm{NFE}}$} & \multirow{2}{*}{ Sugars } & \multirow{2}{*}{$\begin{array}{l}\text { Uric } \\
\text { acid }\end{array}$} & \multirow{2}{*}{$\begin{array}{l}\text { FU/ } \\
\text { kg DM }\end{array}$} & \multirow{2}{*}{$\begin{array}{l}\text { DCP, } \\
\text { kg DM }\end{array}$} \\
\hline & & Ash & $\begin{array}{l}\text { Crude } \\
\text { protein }\end{array}$ & $\begin{array}{l}\text { Ether } \\
\text { extract }\end{array}$ & & & & & & \\
\hline Experiment 1 & & & , & & & & & & & \\
\hline 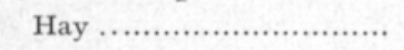 & 84.7 & 6.6 & 11.0 & 2.5 & 32.1 & 47.8 & 7.0 & & 0.65 & 79 \\
\hline 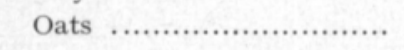 & 86.7 & 2.9 & 14.2 & 6.8 & 9.7 & 66.4 & 2.0 & & 1.16 & 117 \\
\hline Barley ............................. & 87.6 & 2.5 & 14.3 & 1.9 & 5.0 & 76.4 & 3.1 & & 1.16 & 108 \\
\hline Molasses-beet pulp .......... & 86.3 & 6.8 & 13.2 & 0.4 & 14.6 & 64.9 & 24.6 & & 0.97 & 73 \\
\hline Dried poultry manure .... & 92.4 & 22.8 & 31.5 & 2.2 & 19.5 & 24.0 & 0.7 & 9.4 & 0.35 & 236 \\
\hline Soybean meal ................ & 85.6 & 6.1 & 53.3 & 1.0 & 5.9 & 33.7 & 9.1 & & 1.12 & 485 \\
\hline \multicolumn{11}{|l|}{ Experiment 2} \\
\hline 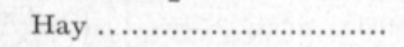 & 93.2 & 6.4 & 9.9 & 1.1 & 35.9 & 46.7 & 7.0 & & 0.53 & 57 \\
\hline Oats ............................... & 90.7 & 3.3 & 15.4 & 5.0 & 9.8 & 66.5 & 2.0 & & 1.07 & 126 \\
\hline Barley ............................ & 89.9 & 2.2 & 14.0 & 2.0 & 4.7 & 77.0 & 3.7 & & 1.16 & 105 \\
\hline Molasses-beet pulp .......... & 93.7 & 7.2 & 13.7 & 0.5 & 14.4 & 64.2 & 23.0 & & 0.97 & 76 \\
\hline Dried poultry manure .... & 94.3 & 24.8 & 34.2 & 1.9 & 17.1 & 22.1 & 0.7 & 7.2 & 0.33 & 309 \\
\hline Soybean meal ................. & 93.6 & 6.6 & 52.0 & 0.7 & 6.2 & 34.6 & 10.8 & & 1.11 & 478 \\
\hline
\end{tabular}

were taken 1, 3, 5 and 8 hours after feeding in Expt. 1 and 0.5, 2.5 and $\mathbf{5 . 5}$ hours after feeding in Expt. 2, so the results of the trials are not directly comparable.

The supplementation of DPM in the diet increased the $\mathrm{pH}$ of the rumen fluid slightly, the difference being significant $(\mathrm{P}<0.01)$ when the inclusion of DPM was $40 \%$. The increase reflected the increased nitrogen intake and rumen fluid ammonia- $\mathrm{N}$ concentration. The uric acid intake in Expt. 1 was on average 48, 84 and $206 \mathrm{~g}$ and in Expt. 246,76 and $152 \mathrm{~g}$ daily, from DPM inclusions of 10,20 and $40 \%$ in the concentrate mixture. The total DM intake was kept constant and crude protein percentages of the different rations were 14.3, 14.2, 14.2, 16.5, 14.6 in Expt. 1 and 14.1, 13.8, 14.4, 15.9 and 14.7 in Expt. 2 when supplementation was $0,10,20,40$ and $0 \%$ of the concentrate, respectively. Rumen fluid $\mathrm{NH}_{3}-\mathrm{N}$ increased with increasing DPM inclusion because of the higher solubility of the nitrogen components in DPM than in soybean and consequent higher nitrogen intake in the diet with $40 \%$ DPM. The differences between rations were significant $(\mathrm{P}<0.05, \mathrm{P}<0.01)$.

OLtJEN et al. (1968) noticed that uric acid was degraded to ammonia in the rumen more slowly than urea, and after a 2-hour latent period the ammonia concentration increased for the uric acid source. The same finding was made here. Koenig et al. (1978) found from data on in vitro cellulose and uric acid disappearence that the rumen microbes were capable of utilising the uric acid nitrogen in poultry excreta after a two- to three day adaptation period and that adapted microbes were capable of degrading uric acid within a 6-hour incubation period. HARMON et al. (1974) and CASWELL et al. (1978) reported higher rumen fluid ammonia concentrations when feeding DPM or processed poultry litter to sheep compared with control protein, the values being on average 
Table 16. Consumption of feeds.

Diets

SBM DPM SBM DPM SBM DPM SBM DPM SPM DPM

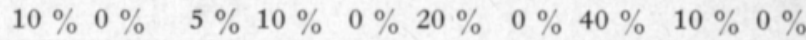

Experiment 1

\begin{tabular}{|c|c|c|c|c|c|}
\hline Hay, $\mathrm{kg}$............................... & 5.1 & 5.1 & 5.1 & 5.1 & 5.1 \\
\hline 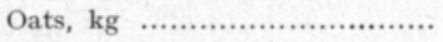 & 2.1 & 2.0 & 1.8 & 1.3 & 2.1 \\
\hline 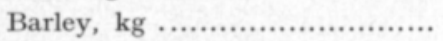 & 2.1 & 2.0 & 1.8 & 1.3 & 2.1 \\
\hline Molasses-beet pulp, $\mathrm{kg}$............. & 0.5 & 0.5 & 0.5 & 0.5 & 0.5 \\
\hline Soybean meal, kg ................. & 0.51 & 0.17 & - & - & 0.51 \\
\hline Dried poultry manure, $\mathrm{kg} \ldots \ldots$ & - & 0.55 & 1.10 & 2.24 & - \\
\hline 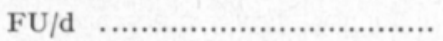 & 8.6 & 8.0 & 7.8 & 6.9 & 8.7 \\
\hline 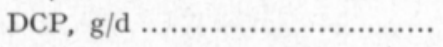 & 903 & 900 & 931 & 1099 & 934 \\
\hline 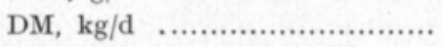 & 10.3 & 10.4 & 10.4 & 10.5 & 10.2 \\
\hline Crude fibre, $g / d$.................... & 2033 & 2097 & 2224 & 2323 & 2037 \\
\hline Uric acid, g/d ...................... & - & 48 & 84 & 206 & - \\
\hline Nitrogen, g/d ........................ & 235 & 236 & 237 & 278 & 239 \\
\hline Sugars, g/d ….................... & 642 & 593 & 642 & 547 & 588 \\
\hline \multicolumn{6}{|l|}{ Experiment $\underline{2} \quad \cdots$} \\
\hline 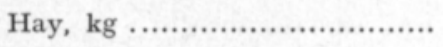 & 5.7 & 6.1 & 6.1 & 5.7 & 5.0 \\
\hline 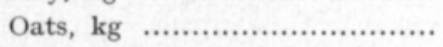 & 2.5 & 2.2 & 1.9 & 1.3 & 2.0 \\
\hline 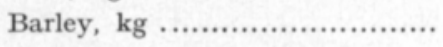 & 2.5 & 2.2 & 1.9 & 1.3 & 2.0 \\
\hline Molasses-beet pulp, $\mathrm{kg}$............. & 0.7 & 0.6 & 0.6 & 0.5 & 0.5 \\
\hline Soybean meal, kg .................... & 0.66 & 0.30 & - & - & 0.51 \\
\hline Dried poultry manure, $\mathrm{kg} . . . .$. & - & 0.59 & 1.14 & 2.15 & - \\
\hline ……...................... & 10.0 & 9.2 & 8.5 & 7.1 & 8.1 \\
\hline 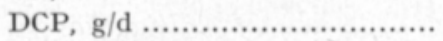 & 1250 & 1208 & 1226 & 1330 & 1032 \\
\hline DM, $\mathrm{kg} / \mathrm{d}$ & 12.0 & 12.0 & 11.6 & 10.8 & 9.9 \\
\hline Crude fibre, g/d ...................... & 2620 & 2701 & 2698 & 2591 & 2147 \\
\hline Uric acid, g/d .......................... & - & 46 & 76 & 152 & - \\
\hline 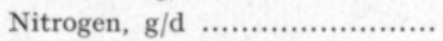 & 270 & 264 & 268 & 275 & 234 \\
\hline 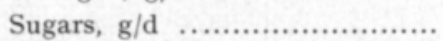 & 774 & 717 & 741 & 564 & 585 \\
\hline
\end{tabular}

$16.0-21.0 \mathrm{mg} / 100 \mathrm{ml}$. These correspond with values given by CLAESSON and AhLström (1974) who found rumen fluid ammonia concentrations of $20 \mathrm{mg} /$ $100 \mathrm{ml}$ in beef cattle and $25 \mathrm{mg} / 100 \mathrm{ml}$ in lactating cows receiving $40 \%$ DPM in concentrate. The values of the present investigation $\left(19.7-35.9 \mathrm{mg} \mathrm{NH}_{3}-\mathrm{N}\right.$ / $100 \mathrm{ml}$ rumen fluid) are in close agreement with all the mentioned values. Consistently more $(\mathrm{P}<0.05)$ rumen fluid ammonia $\left(\mathrm{NH}_{3}-\mathrm{N}\right)$ has been observed by Oltjen and Dinius (1976) in steers fed poultry waste than in steers fed uric acid or sodium urate. With urea in concentrates, rumen fluid ammonia nitrogen values of $50-60 \mathrm{mg} / 100 \mathrm{ml}$ are very common during a long interval between feeds (FonNESBECK et al. 1975). High values of 51.0 and $42.7 \mathrm{mg}$ $\mathrm{NH}_{3}-\mathrm{N} / 100 \mathrm{ml}$ have also been found when soybean was replaced with 25 or $50 \%$ poultry litter nitrogen (BhatTacharya and Fontenot 1965).

In vitro experiments likewise suggest that there is no advantage in having a high ammonia concentration in the rumen fluid. ØRSKOv (1977) was unable 


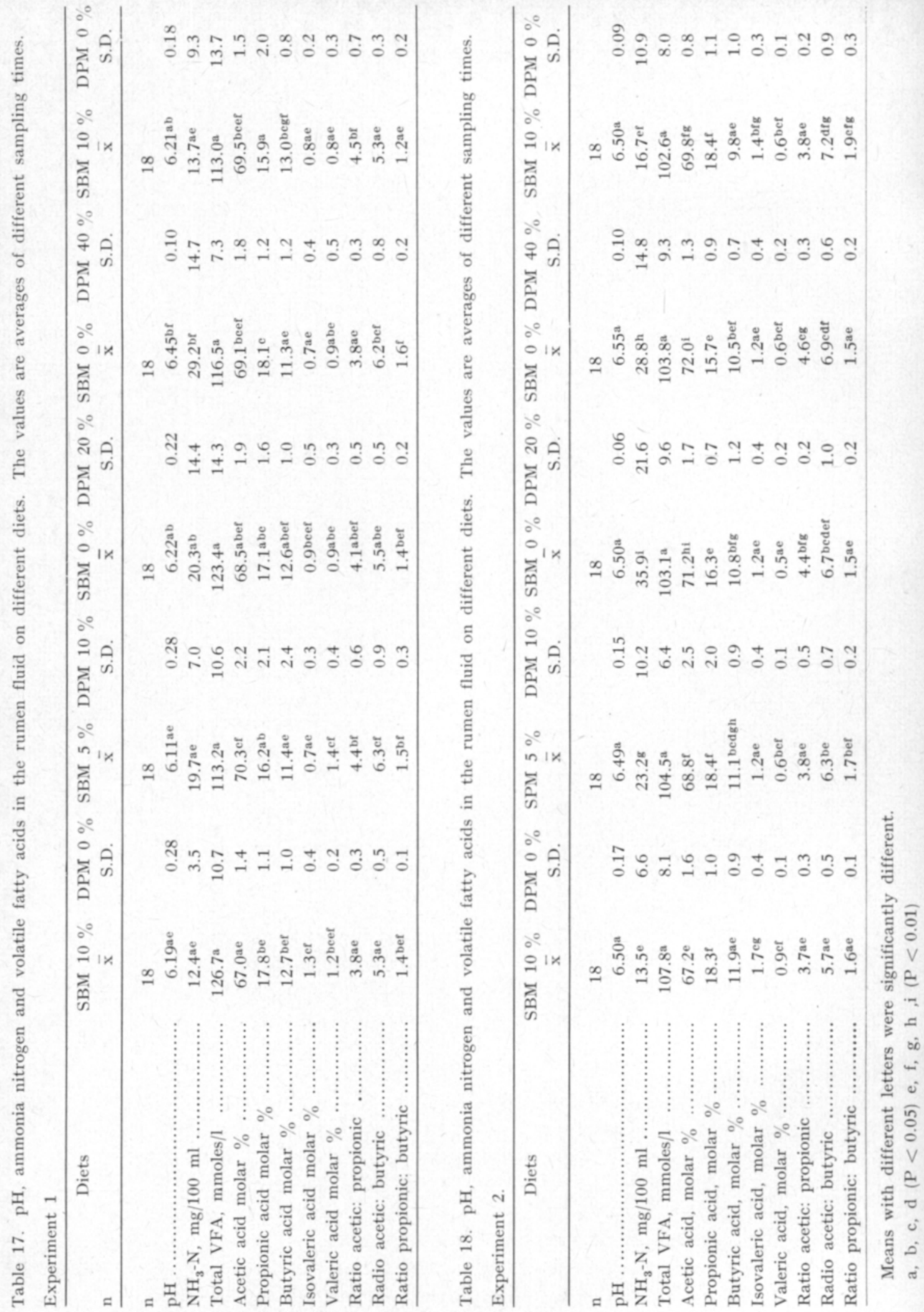


Fig. 13. $\mathrm{pH}, \mathrm{NH}_{3}-\mathrm{N}$ and VFA in the rumen fluid of cows fed different amounts of DPM, Experiment 1 .
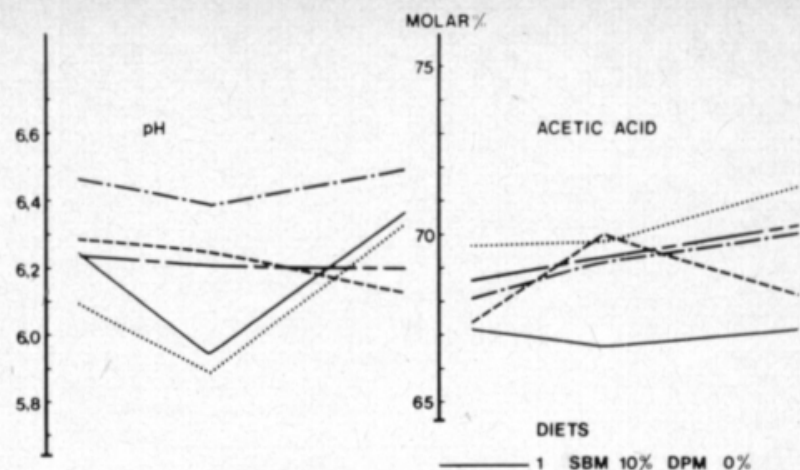

-1 SBM $10 \%$ DPM $0 \%$

2 SBM 5\% DPM $10 \%$

-

$-\cdot-4$ SBM $0 \%$ DPM $40 \%$

$--\square$ SBM $10 \%$ DPM $0 \%$

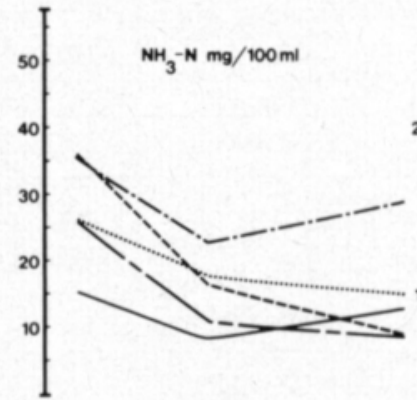

TOTAL VFA mmol//

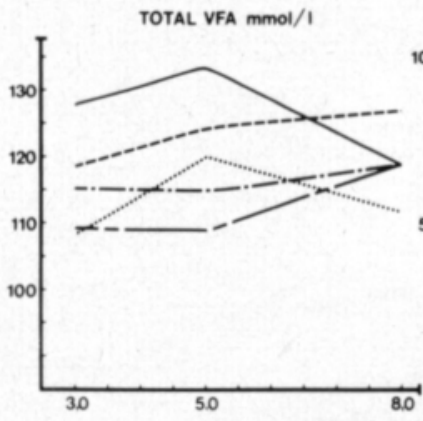

SAMPLING TIME, h AFTER FEEDING
ISOVALERIC+VALERIC ACID

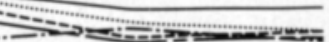

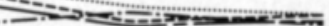

30

to increase the flow of protein from the rumen in sheep when the ammonia rose above $8.8 \mathrm{mg} / 100 \mathrm{ml}$. SATter and SLyter (1973) have found an $\mathrm{NH}_{3}-\mathrm{N}$ limit of $6.3 \mathrm{mg} / 100 \mathrm{ml}$ above which an increase of bacterial protein synthesis could not be found. Allen and Miller (1972) observed that the greatest flow of microbial $\mathrm{N}$ from the rumens of lambs fed a high energy - low protein diet supplemented with urea occurred when the $\mathrm{NH}_{3}-\mathrm{N}$ concentration reached $23.8 \mathrm{mg} / 100 \mathrm{ml}$. In fairly protein free rations Hume (1970) found an optimum $\mathrm{NH}_{3}-\mathrm{N}$ concentration of $20.4 \mathrm{mg} / 100 \mathrm{ml}$ in sheep with re-entrant fistula. Recent measurements of ROFFLER et al. (1976) have shown a requirement level of about $5 \mathrm{mg} / 100 \mathrm{ml}$. Evidently the optimum ammonia level is higher with an increasing urea percentage (KAUFMANN 1977 a).

Rumen ammonia concentration normally fluctuates reaching a peak concentration one to two hours after feeding, and then decreasing. It was found that in cattle fed a minimum of twice daily, with both low and high protein rations, $\mathrm{NH}_{3}-\mathrm{N}$ usually fluctuates 2 and $8 \mathrm{mg} / 100 \mathrm{ml}$ between feedings 


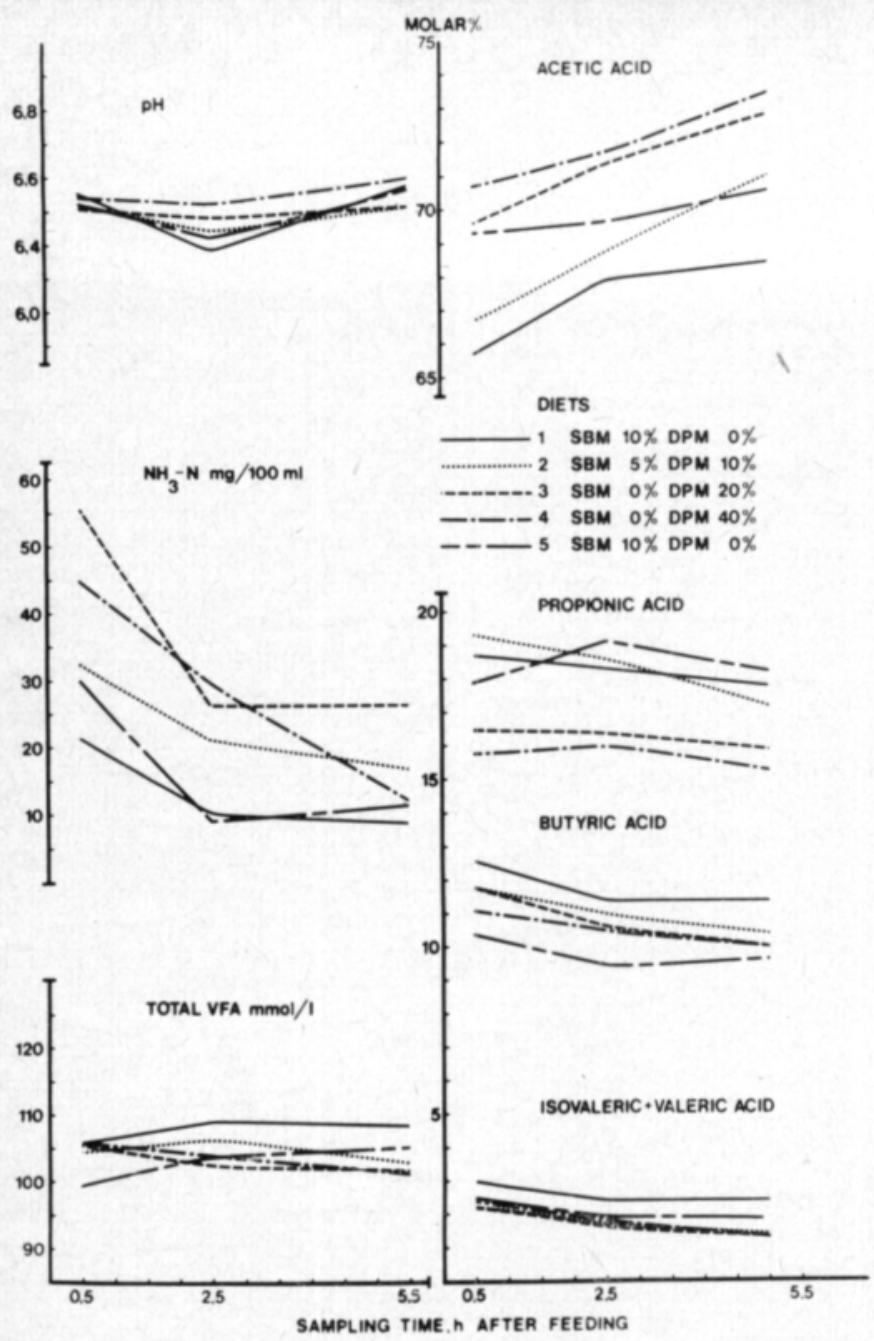

Fig. 14. $\mathrm{pH}, \mathrm{NH}_{3}-\mathrm{N}$ and VFA in the rumen fluid of cows fed different amounts of DPM, Experiment 2 .

when fed to maintain a mean concentration of $5 \mathrm{mg}$ (SATTER and Roffler 1977 b).

It is unclear if the inclusion of DPM causes differences in the total VFA production of the diets. The refusal of diet 5 in Expt. 2 for the concentrate mixture was $25 \%$, which led to some marked anomalies in the results.

Acetic acid as a molar $\%$ was statistically significantly $(\mathrm{P}<0.05, \mathrm{P}<0.01)$ increased with the increasing DPM supplementation, while propionic and butyric acid were decreased. The ratio of acetic to propionic acid increased statistically significantly in Expt. 2 and partially in Expt. $1(\mathrm{P}<0.01)$. Ratios of acetic to butyric and propionic to butyric acid were not linear with amount of DPM supplementation and showed no conclusive trends.

Rumen fluid total VFA concentration has been found to increase with feeding of DPM steers (Cullison et al. 1976) and sheep (Smith and CalverT 1976), though not in all trials (CASWELL et al. 1975, 1978). The higher concentrations of VFA may have been the result of an increased buffering capacity 
provided by the higher ash content of the diet containing DPM (SMrth and Calvert 1976).

The acetic acid molar percentage has been raised in trials of diets containing DPM made by CASWell et al. (1975) and Smith and CALVERT (1976), but not in trials made by Cullison et al. (1976). Butyric acid has also been lowered by the inclusion of DPM in the diet of cows (Smith and CALvERT 1976). Both these trends were observed in the present study. Molar percentages of volatile fatty acids in the rumen fluid of animals fed rations containing DPM were similar to those normally observed for high roughage rations. The roughage to concentrate ratio was 50:50 on a dry matter basis in all of the present rations.

The figures for composition and volume of rumen microbes are given in Tables $19-22$. The ciliates found in the rumen fluid of the experimental animals represented 13 different species but not all species were found in every sample. Of the 18 samples $1,4,3$ and 1 were found to be defaunated when DPM inclusion was $0,10,20$ and $40 \%$ respectively. The genus Entodinium was found in largest numbers in the rumen fluid from every treatment. The numbers of total ciliates were increased with the increasing amount of DPM in the ration, but the differences between diets were not significant $(\mathrm{P}>0.05)$. By comparison, the number of bacteria decreased significantly $(\mathrm{P}<0.05)$. The numbers of Entodinium vorax increased significantly $(\mathrm{P}<0.05)$ and $E$. dilobum increased $(\mathrm{P}<0.01)$ when DPM replaced soybean in the diet.

The number of total ciliates was higher $(\mathrm{P}<0.05) 0.5$ hours after feeding than at the two subsequent sampling times. The differences in the numbers

Table 19. The mean number of ciliates $\left(\mathrm{n} \times 10^{3}\right)$ and bacteria $\left(\mathrm{n} \times 10^{9}\right)$ cells per ml rumen content on different diets.

\begin{tabular}{|c|c|c|c|c|}
\hline Diets & $\begin{array}{l}\text { SBM } 10 \% \\
\text { DPM } \quad 0 \%\end{array}$ & $\begin{array}{c}\text { SBM } 5 \% \\
\text { DPM } 10 \%\end{array}$ & $\begin{array}{r}\text { SBM } 0 \% \\
\text { DPM } 20 \%\end{array}$ & $\begin{array}{c}\text { SBM } 0 \% \\
\text { DPM } 40 \%\end{array}$ \\
\hline Total ciliates ..... & $248^{\mathrm{a}}$ & $302^{\mathrm{a}}$ & $431^{a}$ & $343^{\mathrm{a}}$ \\
\hline Holotrichs .................. & $54^{\mathrm{a}}$ & $86^{a}$ & $83^{\mathrm{a}}$ & $70^{\mathrm{a}}$ \\
\hline 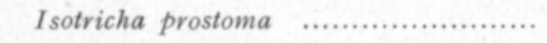 & $12^{\mathrm{a}}$ & $33^{\mathrm{a}}$ & $30^{\mathrm{a}}$ & $31^{\mathrm{a}}$ \\
\hline Dasytricha ruminantum '.................... & $41^{\mathrm{a}}$ & $53^{\mathrm{a}}$ & $53^{\mathrm{a}}$ & $39 \mathrm{a}$ \\
\hline Entodiniomorphs ......................... & $194^{\mathrm{a}}$ & $216^{\mathrm{a}}$ & $348^{\mathrm{a}}$ & $273^{\mathrm{a}}$ \\
\hline 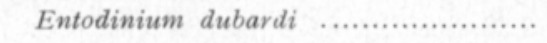 & $28^{\mathrm{a}}$ & $40^{\mathrm{a}}$ & $58^{\mathrm{a}}$ & $36^{\mathrm{a}}$ \\
\hline 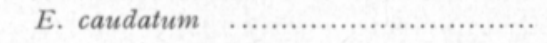 & $54^{\mathrm{a}}$ & $54^{\mathrm{a}}$ & $37 \mathrm{a}$ & $58^{\mathrm{a}}$ \\
\hline 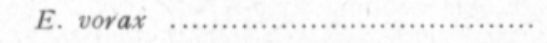 & $9 \mathrm{a}$ & $18^{b}$ & $12^{\mathrm{ab}}$ & $14 \mathrm{ab}$ \\
\hline 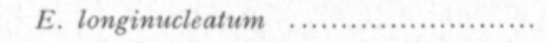 & 31 a & $37^{\mathrm{a}}$ & $91^{b}$ & $43^{\mathrm{a}}$ \\
\hline 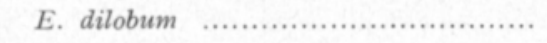 & $6^{e}$ & $16^{d}$ & $10^{\mathrm{ed}}$ & $17^{d}$ \\
\hline 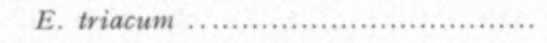 & $38^{b}$ & $26 \mathrm{ab}$ & $19 \mathrm{a}$ & $40^{\mathrm{b}}$ \\
\hline 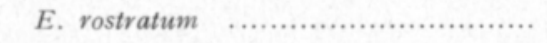 & $6^{\mathrm{a}}$ & $0^{\mathbf{a}}$ & $100^{e}$ & $19^{\mathrm{a}}$ \\
\hline 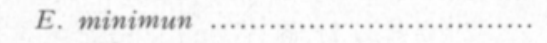 & $7 \mathrm{a}$ & $5^{\mathrm{a}}$ & $15^{e}$ & $6^{\mathrm{a}}$ \\
\hline Eudiplodinium medium .................... & $11^{b}$ & $14^{\text {be }}$ & $4^{\mathbf{a d}}$ & $9 \mathrm{ab}$ \\
\hline 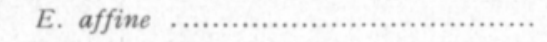 & $1^{\mathrm{a}}$ & $5^{\mathrm{a}}$ & $2^{a}$ & $29^{d}$ \\
\hline Ostracosinium granile ..................... & $2^{a}$ & $0^{\mathrm{a}}$ & $0^{\mathbf{a}}$ & $2^{a}$ \\
\hline Bacteria ............................................. & $37 \mathrm{~b}$ & $29 \mathrm{ab}$ & $30^{\mathrm{ab}}$ & $26^{\mathrm{a}}$ \\
\hline
\end{tabular}

Means with different letters were significantly different.

a, b $(\mathrm{P}<0.05)$, c, d $(\mathrm{P}<0.01)$ 
of Holotrichs were not significant but the numbers of Entodiniomorphs were higher $(\mathrm{P}<0.05) 0.5$ hour after feeding. Numbers of bacteria were higher 0.5 hours after feeding than after 5.5 hours and 2.5 hours $(\mathrm{P}<0.01$ and $\mathrm{P}<0.05$, respectively).

Table 20. The mean number of ciliates $\left(\mathrm{n} \times 10^{3}\right)$ and bacteria $\left(\mathrm{n} \times 10^{9}\right)$ cells per $\mathrm{ml}$ rumen content of different diets at different sampling times after feeding.

\begin{tabular}{|c|c|c|c|}
\hline \multicolumn{4}{|c|}{ Time after feeding } \\
\hline & 0.5 hours & 2.5 hours & 5.5 hours \\
\hline Total ciliates ................. & $422^{\mathrm{b}}$ & $313^{\mathrm{a}}$ & $306^{\mathrm{a}}$ \\
\hline Holotrichs .................... & $98^{\mathrm{a}}$ & $61^{\mathrm{a}}$ & $59^{\mathrm{a}}$ \\
\hline Isotricha prostoma ....... & $36^{\mathrm{a}}$ & $18^{\mathrm{a}}$ & $21^{\mathrm{a}}$ \\
\hline Dasytricha ruminantum & $62^{\mathrm{a}}$ & $43^{\mathrm{a}}$ & $38^{\mathrm{a}}$ \\
\hline Entodiniomorphs ............ & $324^{\mathrm{b}}$ & $252^{\mathrm{a}}$ & $247^{a}$ \\
\hline Entodinium dubardi ..... & $55^{\mathrm{a}}$ & $35^{\mathrm{a}}$ & $35^{\mathrm{a}}$ \\
\hline E. caudatum ................ & $70^{\mathrm{b}}$ & $47^{\mathrm{a}}$ & $43^{\mathrm{a}}$ \\
\hline 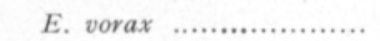 & $18^{\text {bd }}$ & $13^{\mathrm{ab}}$ & $11^{\mathrm{ac}}$ \\
\hline E. longinucleatum ....... & $54^{\mathrm{a}}$ & $45^{\mathrm{a}}$ & $48^{\mathrm{a}}$ \\
\hline E. dilobum ............... & $15^{\mathrm{a}}$ & $11^{\mathrm{a}}$ & $12^{\mathrm{a}^{\prime}}$ \\
\hline E. triacum ...................... & $38^{\mathrm{a}}$ & $31^{\mathrm{a}}$ & $29^{\mathrm{a}}$ \\
\hline E. rostratum ............... & $41^{\mathrm{a}}$ & $44^{\mathrm{a}}$ & $38^{\mathrm{a}}$ \\
\hline E. minimum .............. & $10^{\mathrm{a}}$ & $7^{\mathrm{a}}$ & $8^{\mathrm{a}}$ \\
\hline Eudiplodinium medium & $9^{\mathrm{a}}$ & $9^{\mathrm{a}}$ & $11^{\mathrm{a}}$ \\
\hline E. affine ................... & $12^{\mathrm{a}}$ & 9 a & $10^{\mathrm{a}}$ \\
\hline Ostracosinium granile .... & $2^{\mathrm{a}}$ & $1^{\mathrm{a}}$ & $2^{\mathrm{a}}$ \\
\hline Bacteria .......................... & $36^{\text {bd }}$ & $30^{\mathrm{ab}}$ & $25^{\mathrm{ac}}$ \\
\hline
\end{tabular}

Means with different letters were significantly different.

a, b $(\mathrm{P}<0.05)$; c, d $(\mathrm{P}<0.01)$

The numbers of various species of ciliates varied between samples and diets and in some samples ciliates were completely lacking. It has been shown in many experiments that even in animals given the same dietary and environmental treatment the rumen microbial populations may differ greatly both quantitatively and qualitatively (HuNGATE 1966) and temporal variation may be marked (EADIE et al. 1970).

Statistically significant $(\mathrm{P}>0.05)$ differences between the present diets were not found in either the volume of ciliates or bacteria mass. The variability in individual samples was quite large, however. The differences in total volume of the microbial mass between sampling times were not statistically significant $(\mathrm{P}>0.05)$.

The proportion of the total volume of the microbe mass in the rumen content (Tables 21 and 22) was found to be on average $4.0 \%$ and $4.4,4.0,4.0$ and $3.7 \%$ when DPM was $0,10,20$ and $40 \%$ of the concentrate mixture. The corresponding values at $0.5,2.5$ and 5.5 hours after feeding were $4.9,3.8$ and $3.5 \%$, respectively. 
Table 21. Total volume of microbe mass of rumen content on different diets $\left(\mu^{3} \times 10^{7}\right)$ per ml rumen content.

\begin{tabular}{|c|c|c|c|c|c|c|c|c|}
\hline Diets & $\begin{array}{c}1 \text { SBM } 10 \% \\
\text { DPM } 0 \%\end{array}$ & $\%$ & $\begin{array}{l}2 \text { SBM } 5 \% \\
\text { DPM } 10 \%\end{array}$ & $\%$ & $\begin{array}{l}3 \text { SBM } 0 \% \\
\text { DPM } 20 \%\end{array}$ & $\%$ & $\begin{array}{l}4 \text { SBM } 0 \% \\
\text { DPM } 40 \%\end{array}$ & $\%$ \\
\hline Total ciliates ........ & 674 & 15.5 & 1179 & 29.2 & 1047 & 25.9 & 1056 & 28.6 \\
\hline Holotrichs ......... & 248 & & 438 & & 403 & & 369 & \\
\hline Entodiniomorphs & 441 & & 740 & & 643 & & 710 & \\
\hline Bacteria $\ldots \ldots \ldots \ldots \ldots$ & .. 3684 & 84.5 & 2863 & 70.8 & 2994 & 74.1 & 2642 & 71.4 \\
\hline Total volume $. . . \ldots .$. & .. 4359 & & 4042 & & 4041 & & 3698 & \\
\hline
\end{tabular}

Table 22. Total volume of microbe mass of rumen content at different sampling time $\left(\mu^{3} \times 10^{7}\right)$ per $\mathrm{ml}$ rumen content.

\begin{tabular}{|c|c|c|c|c|c|c|}
\hline \multicolumn{7}{|c|}{ Sampling times after feeding } \\
\hline & 0.5 hours & $\%$ & 2.5 hours & $\%$ & 5.5 hours & $\%$ \\
\hline Total ciliates & 1269 & 26.0 & 849 & 22.5 & 894 & 25.6 \\
\hline Holotrichs .................. & 491 & & 297 & & 333 & \\
\hline Entodiniomorphs . ........ & 808 & & 565 & & 561 & \\
\hline Bacteria $\ldots \ldots \ldots \ldots \ldots \ldots \ldots$ & 3605 & 74.0 & 2932 & 77.5 & 2601 & 74.4 \\
\hline Total volume .................. & 4874 & & 3781 & & 3495 & \\
\hline
\end{tabular}

The bacteria proportion on the different diets averaged $75.3 \%$ and that of ciliates $24.7 \%$ of the total microbial volume. DPM supplementation lowered the bacterial volume of the total volume and the volume of ciliates was higher. These volumes corresponds to the numbers of ciliates and bacteria with the different diets. The cell numbers and total cell volumes corresponded on the different diets.

The numbers of total ciliates found in this study were much lower than those found by SYRJ $\ddot{L} L \ddot{A}$ et al. (1978) in a study with cows fed skimmilk powder as protein supplement. Their values varied from 767 to $1723 \times 10^{3}$ cells $/ \mathrm{ml}$ rumen fluid. The numbers of bacteria were comparable. Milk protein is much more soluble than soybean meal (KAUFMANN 1977 a), so protein synthesis is higher in the rumen.

On a restricted grain ration Coleman (1975) reported that each $\mathrm{ml}$ of rumen liquor contained the following volumes of protozoa: Epidinia $0.03 \mathrm{ml}$, Entodinia $0.07 \mathrm{ml}$, Isotrichs $0.05 \mathrm{ml}$ and medium sized protozoa $0.03 \mathrm{ml}$. The volume occupied by the bacteria was only $0.03 \mathrm{ml}$, corresponding to $20 \%$ of the total volume of the micro-organisms. In this study the volume of bacteria was comparable, and the volume of protozoa was much lower; the protozoa constituted only about $25 \%$ of the total microbe mass.

On some special diets, such as those with a high urea content, all ciliates may be lacking (Virtanen 1966, Mäkinen 1972). Oltjen et al. (1966) have reported that the ruminal ingesta of cattle fed purified diets are frequently devoid of protozoa and have increased bacterial populations. When protein free diets are used the protozoa disappear from the rumen and the number of bacteria increases (VIRTANEN 1971). With using uric acid or DPM as nitrogen source there is no observations of the effect on the microbial population. 


\section{General conclusions}

The shortage and cost of conventional protein supplemenst for ruminant diets is forcing producers to look for alternative raw materials. In this context there is interest in dried poultry manure, although part of this interest also stems from the need to find ways of disposing of droppings from intensive poultry production systems.

The composition of poultry excreta is highly variable, depending upon the ingredients of the diet of the birds and the environmental conditions under which the droppings are kept. The nature of the dehydrating process significantly affects the composition, moisture content, texture and odour of the resulting product.

Poultry excreta contains considerable amounts of crude protein, on average $30 \%$ in DM. NPN is the major portion of the total nitrogen in DPM, the main NPN component being uric acid which constitutes 20 to $60 \%$ of the total nitrogen. Rumen microorganisms are capable of efficient utilisation of uric acid as a nitrogen source. In terms of protein and amino acids, DPM is broadly equivalent to a cereal such as barley.

The primary deficiency of DPM is the low energy value $(0.34-0.35 \mathrm{FU} / \mathrm{kg}$ DM): for the large amounts of manure necessary to meet energy needs would make the ration too bulky. The FU-value of the present isonitrogenous concentrate mixture containing $20 \%$ DPM was $13 \%$ lower than the soybean meal and urea mixtures. The ash content and mineral value of DPM were high.

The feed intake was equal in all groups but due to the lower energy value of the concentrate mixture including the DPM the energy requirement of cows in the first part of the experiment could not be met. The intake of the concentrate mixture with DPM, as a percentage of the offered ration, was lower than with soybean or urea. Adaptation periods of $1-3$ weeks were necessary before maximal levels of intakes of rations containing DPM were achieved.

The DM digestibility of rations including DPM was $2-3 \%$-units lower than other rations. There were no significant differences between the protein sources in the milk production, milk constituents, or the composition of the milk. On average there were only small differences in the milk production and milk composition of the two experiments. This may be due to sample size and variation among the cows. Energy and protein utilisation was better in the DPM group in the second trial.

Urea had only limited value for high producing cows during early lactation as the degradation of dietary plant protein of the diets supplied adequate ammonia for maximal microbial synthesis. The peak yields of cows receiving urea was lower than of cows fed DPM or SBM. The utilisation of NPN from DPM is not very efficient in high yielding dairy cows.

The values obtained in hematological and blood chemical analyses of the blood samples were within the normal range, and the biological significance of statistical differences is therefore difficult to asses. There was a positive relationship between blood urea nitrogen and the total amount of dietary crude protein in excess of requirements, regardless of the protein supplement used. From the values of the various blood metabolic parameters one can 
conclude that DPM in moderate amounts has no detrimental effects on the health of dairy cows.

The different treatments had no marked effects on the rumen fermentation except for the concentration of ammonia- $\mathrm{N}$ of rumen fluid which was increased with increasing DPM in the ration. The molar percentage of acetic acid of total VFA amount increased and propionic acid and butyric acid decreased, when DPM inclusion increased.

The numbers of ciliates increased and bacteria decreased with greater DPM inclusion. Likewise the proportion of ciliate mass increased and bacteria mass decreased. The total volume of microbial mass was about $10-20 \%$ higher with the SBM than the DPM diet. Nitrogen was in excess relative to energy with the DPM diet and the utilisation of ammonia was not as efficient.

The results obtained serve further to indicate that dried poultry manure in combination with feed produced on the farm can replace a great part of the vegetable protein feed supplement for high yielding dairy cows, and urea may be beneficial as a supplement in high-energy low-protein diets such as grain concentrate feeds. Higher milk yields may be expected with conventional protein supplementation.

\section{REFERENCES}

Adams, R. S., Stout, W. L., Kradel, D. C., Guss, S. B. Jr, Moser, B. L. \& Jung, G. A. 1978. Use and limitations of profiles in assessing health or nutritional status of dairy herds. J. Dairy Sci. 61: $1671-1679$.

AнLströм, B. 1974. Torkad burhösgödsel (Tyrea) som proteinfodermedel till mjölkkor. Alnarp. 1972. Kungsängen 1972. Inst. Husdj. utfodr. vård. Landbr. högsk. Stencil. $12 \mathrm{p}$.

Alexander, D. C., Carriere, J. A. J. \& Mc Kay, K. A. 1968. Bacteriological studies of poultry litter fed to livestock. Canad. Vet. J. 9: 127-131.

Allen, S. A. \& Miller, E. L. 1972. The effect of urea supplementation on the nitrogen reaching the abomasum of lambs. Proc. Nutr. Soc. 31: $26 \mathrm{~A}$.

ANoN. 1975. Laki: Sika-ja kanataloustuotannon ohjaaminen eräissä tapauksissa, No 302/9. 5. 1975.

- 1976. Hylps-käsikirja. Helsingin yliopisto, Laskentakeskus. Mimeogr. 231 p.

Arndt, D. L., Day, D. L. \& Hatfield, E. E. 1979. Processing and handling of animal excreta for refeeding. J. Anim. Sci. 48: 157-162.

Bath, D. L., Ronning, M., Mayer, J. H. \& Lofgren, G. P. 1965. Caloric equivalent of liveweight loss in cattle. J. Dairy Sci. $48: 374-380$.

Belasco, I. J. 1954. New nitrogen feed compounds for ruminants - a laboratory evaluation. J. Anim. Sci. 13: 601-610.

BelyeA, R. L., Coppock, C. E. \& LAKE, G. B. 1975. Effects of silage diets on health, reproduction and blood metabolites of dairy cattle. J. Dairy Sci. 58: 1336-1346.

Bhattacharya, A. N. \& Fontenot, J. P. 1965. Utilization of different levels of poultry litter nitrogen by sheep. J. Anim. Sci. 24: 1174-1178.

- \& Fontenot, J. P. 1966. Protein and energy value of peanut hull and wood shaving poultry litters. J. Anim. Sci. 25: 367 .

- \& TAYlor, T. C. 1975. Recycling animal waste as a feedstuff: A review. J. Anim. Sci. $41: 1438-1457$. 
Biely, J., Soong, R., Serer, L. \& Pope, W. H. 1972. Dehydrated poultry waste in poultry rations. Poult. Sci. 51: $1502-1511$.

- \& Stapleton P. 1976. Recycled dried poultry manure in chick starter diets. Br. Poult. Sci. 17: 5-12.

BINES, J. A. 1976. Factors influencing voluntary intake of cattle. SwAN, H. and Broster, W. H. (Ed.). Principles of cattle Production. p. 287-305, Butterworth, London.

BLAIR, R. 1975. Utilizing wastes in animal feeds - A European overview. Feedstuffs 47 (26): 16, $33-34$.

- \& KNight, D. W. 1973 a. Recycling animal wastes. I. Feedstuffs, 45, (10), 32-34.

- \& KNight, D. W. 1973 b. Recycling animal wastes. II. Feedstuffs 45, (12), $31-35$.

Broster, W. H. \& Alderman, G. 1977. Nutrient requirements of the high yielding cows. Livest. Prod. Sci. 4: 263-275.

Brugman, H. H., Dickey, H. C., Plummer, B. E., Goater, J., Heiteman, R. N. \& Taka, M. R. Y. 1968. Drug residues in lamb carcasses fed poultry litter. J. Anim. Sci. 27: 1132.

- , Dickey, H. C., Plummer, B. E. \& Poulton, B. R. 1964. Nutritive value of poultry litter. J. Anim. Sci. 23: 869.

- Dickey, H. C., Plummer, B. E. \& Poulton, B. R. 1967. Digestibility of sterilized poultry litter. J. Anim. Sci. 26: 915.

Bucholtz, H. F., Henderson, H. E., Thomas, J. W. \& Zindel, H. C. 1971. Dried animal waste as a protein supplement for ruminants. Livestock Waste Management and Pollution Abatement. Proc. Int. Symp. on Livestock waste. ASAE Publ. Proc. 271: 308-310. Columbus, Ohio.

BulL, L. S. \& REID, J. T. 1971. Nutritive value of chicken manure for cattle. Livestock Waste Management and Pollution Abatement. Proc. Int. Symp. on Livestock Waste. ASAE Publ. Proc. 271: 297-300. Columbus, Ohio.

Burroughs, W., Nelson, D. K. \& Mertens, D. R. 1975 . Evaluation of protein nutrition by metabolizable protein and urea fermentation potential. J. Dairy Sci. 58: 611-619.

Вӧнме, H. 1972. Möglichkeiten der Verfütterung von getrockneten Geglügelkot. Jahrestagung des Verbandes Landw. Untersuchungs- und Forschungsanstalten, Mainz.

Calvert, C. C. 1974. Animal wastes as substrates for protein production Feder. Proc. 33: $1938-1939$.

- 1979. Use of animal excreta for microbial and insect protein synthesis. J. Anim. Sci. 48: $178-192$.

- \& KrNG, R. L. 1977. Dehydrated caged laying hen excreta (DEP) as a nitrogen supplement for lactating cows. Amer. Dairy Sci. Assoc. 72 Ann. Meet. Ames Iowa.p. $141-$ 142.

Caraway, W. T. \& Hald, P. M. 1963. Uric acid. Standard Methods Clin. Chem. 4: $239-247$.

Caswell, L. F., Fontenot, J. P. \& WebB, K. E. Jr. 1975. Effect of processing method on pasturization and nitrogen components of broiler litter and on nitrogen utilization by sheep. J. Anim. ci. 40: 750-759.

-, Fontenot, J. P. \& WeBB, K. E. Jr. 1978. Fermentation and utilization of broiler litter ensiled at different moisture levels. J. Anim. Sci. 46:547-561.

Chalupa, W. 1975. Rumen bypass and protection of proteins and amino acids. J. Dairy Sci. 58: $1198-1218$.

Chaney, A. L. \& Marbach, E. P. 1962. Modified reagents for determination of urea and ammonia. Clin. Chem. 8: 130-132.

Claesson, O. \& Ahlström, B. 1974. Poultry manure as a feed for dairy cows. XIX Internat. Dairy Congr. IE: $88-89$.

Clark, J. H. 1975. Lactational responses to postruminal adminisration of protein and aminoacids. J. Dairy Sci. 58: 1178-1197.

Coleman, G. S. 1975. The interrelationship between rumen ciliate protozoa and bacteria. McDonald, I. W. \& Warner, A. C. I. (Ed.). Physiology and digestion in the ruminant. p. 149-164. Australia: University of New England.

Couch, J. R. 1972. Feeding poultry manure to animals. Feedstuffs $44(31): 24-25,27$.

Greger, C. R., Gardner, F. A. \& FARR, F. M. 1973. Broiler litter silage for fattening beef animals. Feedstuffs $45(3): 25$. 
Cullison, A. E., McCampbell, H. C., Cunningham, A. C., Lowrey, R. S., Warren, E. P., McLendon, B. D. \& Sherwood, D. H. 1976. Use of poultry manures in steer finishing rations. J. Anim. Sci. 42: 219-228.

Dimopoullos, G. T. 1970. Plasma proteins. Kaneko, J. J. \& Cornelius, C. E. (Ed.). Clinical biochemistry of domestic animals. p. 97-125. Acad. Press. London, New York.

Drake, C. L., Mc Clure, W. H. \& Fontenot, J. P. 1965. Effects of levels and kind of broiler litter for fattening steers. J. Anim. Sci. 24: 875.

Dugan, G. L., Golueke, C. G., Oswald, W. J. \& Rixford, C. E. 1970. Photosynthetic reclamation of agricultural solid and liquid wastes. SERL Report No 70-1. Univ. of Calif.

Durst, H. I., Willett, L. B., Brumm, C. J. \& Schanbacher, F. L. 1978. Changes in blood and urine composition from feeding polybrominated biphenyls to pregnant Holstein heifers. J. Dairy Sci. 61: 199-205.

Eadie, J. M., Hyldgandd-Jensen, J., Mann, S. O., Reid, R. S. \& Whitelaw, F. C. 1970. Observations on the microbiology and biochemistry of a pelleted barley ration. Br. J. Nutr. 24: 157-177.

EKERN, A. 1972. Feeding of high yielding cows. IV. Ration digestibility in high yielding cows fed at different levels of intakes. Meld. Norg. Landbr. Høgsk. 51 (33): 1-18.

El-Sabban, F. F., Bratzler, J. W., Long, T. A., Frear, D. E. H. \& Gentry, R. F. 1970. Value of processed poultry waste as a feed for ruminants. J. Anim. Sci. 31: 107-111.

Es, A. J. H. VAN 1976. Factors influencing the efficiency of energy utilization by beef and dairy cattle. Swan, H. \& Broster, W. H. (Ed.), Principles of cattle production. p. 237-253. Butterworth, London.

Essig, H. W. 1975. Recycling nutrients for livestock. Feedstuffs 47 (21): 35, 43.

Evans, E., Morgan, E. T. Jr. \& Walker, J. P. 1978 a. Laying hen excreta as a ruminant feedstuff I. Influence of practical extremes in diet, waste management procedure and stage of production on composition. J. Anim. Sci. 46: 520-526.

Morgan, E. T. Jr., Macleed, G. K. \& Turner, E. M. Jr. 1978. Laying hen excreta as a ruminant feedstuff II. Preservation and acceptability of wet excreta by sheep. J. Anim. Sci. 46:527-534.

Flegal, C. J., Sheppard, C. C. \& Dorn, D. A. 1972. The effects of continuos recycling and storage of nutrient quality of dehydrated poul try waste (DPM). Proc. 1972. Cornell Agric. Waste Manag. p. 295-300.

- \& ZindeL, H. C. 1970. The utilization of poultry waste as a feedstuff for growing chicks. Mich. St. Univ. Agric. Exp. Sta. Res. Rep. 117: 21-28.

Fonnesbeck, P. V., Kearl, L. C. \& Harris, L. E. 1975. Feed grade biuret as a protein replacement for ruminants. A review. J. Anim. Sci. 40: 1150-1184.

Fontenot, J. P., Bhattacharya, A. N., Drake, C. L. \& McClure, W. H. 1966. Value of broiler litter as feed for ruminants. Proc. Natl. Symp. on Anim. Waste Management ASAE Publ. Proc. SP-0036: 105-108.

Fontenot, J. P., McClure, W. H., Kelly, R. F. \& Litron, G. W. 1963. The value of poultry litter as feedstuffs for fattening beefsteers. Va. Agr. Exp. Sta. Livestock Res. Proc. Rep. p. 9-12.

- , Tucker, R. E., Harmon, B. W., Libbe, K. G. \& Moore, W. E. 1970. Effects of feeding different levels of broiler litter to sheep. J. Anim. Sci. 30: 319.

- \& WEBв, K. E. Jr. 1974. The value of animal wastes as feeds for ruminants. Feedstuffs $46(14): 30-31,33$.

-, Webb, K. E. Jr., Buehler, R. J., Harmon, B. W. \& Philips, W. 1972. Effects of feeding different levels of broiler litter to ewes for long periods of time on performance and health. Livestock Res. Rep. Va. Polytech. Inst. and State Univ., Blacksburg. 145: 33 .

- \& WebB, K. E. Jr., Libke, K. G. \& Buehler, R. J. 1971 a. Performance and health of ewes fed broiler litter. J. Anim. Sci. 33: 283.

- , Webb, K. E. Jr., Harmon, B. W., Tucker, R. E. \& Moore, W. E. C. 1971 b. Studies of processing nutritional value and palatability of broiler litter for ruminants. Livestock Waste Management and Pollution Abatement. Proc. Int. Symp. on Livestock Waste. ASAE Publ. Proc. 271: 301-304. Columbus, Ohio. 
GERI, G. 1968. Growth intake of feed and results of rearing of young pigs fed on mixtures containing poultry droppings. Aliment. anim. 12:559-567 (Engl. sum.).

Griel, L. C. Jr., Kradel, D. C. \& Wickersham, E. W. 1969. Abortion in cattle associated with feeding of poultry litter. Cornell Vet. 59: 226-235.

Hagemeister, H. \& Kaufmann, W. 1974. Der Einfluss der Rationsgestaltung auf die Verfügbarkeit von Protein-N bzw. Aminosäure-N im Darm der Milchkuh. Kieler Milchw. Forschungsber. 26: 199-220.

- Kaufmann, W. \& Pfeffer, E. 1976. Factors influencing the supply of nitrogen and amino acids to the intestine of dairy cows. Protein metabolism and nutrition. EAAP, Publ. 16. p. 425-439. Butterworths, London.

Halbrook, E. R., Winter, A. R. \& Sutton, T. S. 1951. the microflora of poultry house litter and droppings. Poult. Sci. 30:381-388.

Harmon, B. W., Fontenot, J. P. \& WebB, K. E. Jr. 1974. Effect of processing method of broiler litter nitrogen utilization by lambs. J. Anim. Sci. 39: 942-946.

- , Fontenot, J. P. \& WeBb, K. E. Jr. 1975 a. Ensiled broiler litter and corn forage I. Fermentation characteristics. J. Anim. Sci. 40: 144-155.

- , Fontenot, J. P. \& WeBB, K. E. Jr. 1975 b. Ensiled broiler litter and corn forage II. Digestibility, nitrogen utilization and palatability by sheep. J. Anim. Sci. 40: 156 -160 .

HaRnisch, S. 1974. Energie- und Stickstoffsumsatz nach Verfütterung von Geflügel-Trockenkot an Legehennen. Arch. Geflügelk. 38:1-4.

Hashimoтo, A. G. 1974. Characterization of white leghorn manure. Proc. the 1974 Cornell Agric. Waste Managem. Conf. p. 141-152.

Helmer, L. G. \& Bartley, E. E. 1971. Progress in the utilization of urea as a protein replacer for ruminants. J. Dairy Sci. 54: 25-51.

Henry, R. J., Cannon, D. C. \& Winkelman, J. W. 1974. Clinal Chemistry: Principles and Technics. 1629 p. 2nd Ed. New York.

Hewetr, C. 1974. On the causes and effects of variations in the blood profile of Swedish dairy cattle. Acta et. scand. Suppl. 50:1-152.

Hodgetrs, B. 1971. The effects of including dried poultry waste in the feed of laying hens. Livestock Waste Mangement and Pollution Abatement. Proc. Int. Symp. on Livestock Waste. ASAE Publ. Proc. 281: 311-313. Columbus, Ohio.

Howes, J. R. 1968. Management and utilization of poultry wastes. Feédstuffs $50(50): 22-23$.

HuBER, J. T. 1975. Protein and nonprotein nitrogen utilization in practical dairy rations. J. Anim. Sci. 41: 954-961.

- Andrus, D. F., Erickson, R. E. \& Polan, C. E. 1972. Influence of production on response to high urea or low protein intakes. J. Dairy Sci. 55: 708-709.

HuIDA, L. 1973. Quantitative determination of volatile fatty acids from rumen sample and silage by gas-liquid chromatography. J. Scinet. Agric. Soc. Finl. 45: 483-488.

Hultman, E. 1959. Rapid specific method for determination of aldosaccharides in body fluids. Nature 183: 108-109.

Hume, I. D., Morr, R. J. \& Somers, M. 1970. Synthesis of microbial protein in the rumen. I. Influence of the level of nitrogen intake. Aust. J. agric. Res. 21: 283-296.

Hungate, R. E. 1966. The rumen and its microbes. 544 p. Acad. Press. New York.

Hyvärinen, A. \& NikкiLÄ, E. 1962. Specific determination of blood glucose with 0-toluidine. Clin. Chim. Acta 7:140-143.

Jackson, S. W., Langlois, B. E. \& Johnson, T. H. 1970. Growth of micro-organism in fresh chicken manure under aerobic and anaerobic conditions. Poult. Sci. 49: 1749-1750.

Jones, G. M., Stephens, C. \& Kensetr, B. 1975. Utilization of starea, urea or soybean meal in complete rations for lactating dairy cows. J. Dairy Sci. 58: 689-695.

Jurtshuk, P., Doetsch, R. N. \& Shaw, J. C. 1958. Anaerobic purine dissimilation by washed suspensions of bovine rumen bacteria. J. Dairy Sci. 41: 190-202.

Jönsson, E. 1976. Burhönsgödsel - hantering och avsättning. Landbrugshögsk. Konsul. avd. stencils. Husdjur. 48. 55 p.

KaUfmann, W. 1977 a. Economic and other considerations covering decisions on the advisability of incorporating additional and new sources of protein and nonprotein nitrogen into diet of beef cattle. Symp. Recent developments in the use of new sources of 
protein, essential amino acids and non-protein nitrogen with special reference to ruminants. FAO, AGRI/SEM. 7. Mimeogr. 26 p.

- $1977 \mathrm{~b}$. Calculation of the protein requirements for dairy cows according to measurements of $\mathrm{N}$ metabolism. Protein metabolism and nutrition. EAAP Publ. 22: 130 -132 .

- \& Hagemeister, H. 1975. Zur Wervertung von Harnstoff (NPN) beim Wiederkäuer. Übers. Tierernähr. 3:33-65.

Kiefer, H. 1971. Hühnerdung als Futtermittel. Dt. Geflügelwirschaft 23:55-556.

Kimura, F. T. \& Mrller, V. L. 1957. Improved determination of chromic oxide in cow, feed and feces. J. Agr. Food Chem. 5: 216.

Kneale, W. A. \& Garstang, J. R. 1975. Milk production from a ration containing dried poultry waste. Expl. Husb. 28: 18-24.

Koenig, S. E., Hatfield, E. E. \& Spears, J. E. 1978. Animal performance and microbial adaptation of ruminants fed formaldehyde treated poultry waste, J. Anim. Sci. 46: $490-498$.

Kraft, D. J., Olechowski-Gerhardt, C., Berkowitz, J. \& Finstein, M. S. 1969. Salmonella in wastes produced at commercial poultry farms. Appl. Microbiol. 18: 703-707.

Kristensen, V. F., Andersen, P. A., KJaegaard-Jensen, G., Fisker, A. N. \& Birkkjaer, H. E. 1976. Tørret fjerkaegødnings fodervaerdi til malkekøer og dens indflydelse på mejeriprodukternes kvalitet. Faellesudvalget for Statens Mejeri og Husdyrbrugsforsøg. 2. beret. $48 \mathrm{p}$.

Kubena, L. F., ReEce, F. N. \& MaY, J. D. 1973. Nutritive properties of broiler excreta as influenced by environmental temperature, collection interval, age of broilers and diet. Poult. Sci. 52: $1700-1703$.

Kwan, K., Coppock, C. E., Lake, G. B., Fettman, M. J., Chase, L. E. \& McDowell, R. E. 1977. Use of urea by early postpartum Holstein cows. J. Dairy Sci. 60: 1706-1724.

LAIRD, C. W. 1972. Representative values for animal and veterinary populations and their clinical significances. Hycel. Inc. Howston. Tx. p. 7-26.

LEE, D. J. W. \& BLAIR, R. 1972. Effects on chick growth of adding various non-protein nitrogen sources and dried autoclaved poultry manure to diets containing essential amino acids. Br. Poult. Sci. 13: 243-249.

- \& BLAIR, R. 1973. Growth of broilers fed on diets containing dried poultry manure. Br. Poult. Sci. 14: 379-388.

Lee, A. J., Twardock, A. R., Bubar, R. H., Hall, J. E. \& Davis, C. L. 1978. Blood metabolic profiles: Their use and relation to nutritional status of dairy cows. J. Dairy Sci. 61: $1652-1670$.

LEwIS, D. 1957. Blood urea concentration in relation to protein utilization in ruminants. J. Agr. Sci. 48: $438-446$.

Liebholz, J. 1969. Poultry manure and meat meal as a source of dietary nitrogen for sheep. Aust. J. Exp. Agr. Anim. Husb. 9: 589-593.

Little, W. 1974. An effect of stage of lactation on the concentration of albumin in the serum of dairy cows. Res. Vet. Sci. 17: 193-199.

LOEHR, R. C. 1974. Environmental Sciences. Agricultural waste management: Problems, processing and approaches. $576 \mathrm{p}$. New York.

Long, T. A., Bratzler, J. W. \& Frer, D. E. H. 1969. The value of hydrolyzed and dried poultry waste as a feed for ruminant animals. Cornell Conf. on Agric. Waste Management, p. $98-104$.

Lovett, J., Messer, J. W. \& Read, R. B. Jr. 1971. The microflora of Southern Ohio poultry litter. Poult. Sci. 50: $746-751$

Lowman, B. G. \& KNight, D. W. 1970. A note on apparent digestibility of energy and protein in dried poultry excreta. Anim. Prod. 12: 525-528.

Manoukas, A. G., Colouos, N. F. \& Dawis, H. A. 1964. Losses of energy and nitrogen in drying excreta of hens. Poult. Sci. 43:547-549.

Manston, R., Rusell, A. M., Dew, S. M. \& Payne, J. M. 1975. The influence of dietary protein upon blood composition in dairy cows. Vet. Rec. 96: 497-502.

McCaskey, T. \& Anthony, W. B. 1979. Human and animal health aspects of feeding livestock excreta. J. Anim. Sci. 48: 163-177. 
McCullough, H. 1967. The determination of ammonia in whole blood by a direct colorimetric method. Clin. Chem. Acta 17: 297-304.

McInnes, P., Austin, P. J. \& Jenkins, D. L. 1968. The value of a poultry litter and wheat mixture in the drought feeding of weaner sheep. Austr. J. Exp. Agr. Anim. Husb. 8: 401 .

McNab, J. M., LeE, D. J. W. \& Shannon, D. W. F. 1972. The growth of broiler chickens fed low-protein diets containing triammonium citrate, diammonium hydrogen citrate and auctoclaved dried poultry manure. Br. Poult. Sci. 13: 357-364.

- , Sannon, D. W. F. \& Blair, R. 1974. The nutritive value of a sample of dried poultry manure for the laying hen. Br. Poult. Sci. 15: 159-166.

McNABB, F. M. A. \& Mc NABB, R. A. 1975. Proportions of ammonia, urea and total nitrogen in avian urine and quantitative methods for their analysis on a single urine sample. Poult. Sci. 54: 1498-1505.

McNiven, M., Summers, J. D. \& Leeson, S. 1976. Liquid diets containing poultry wastes for ruminants. Can. J. Anim. Sci. 56: 221-225.

Messer, J. W., Lovett, J., Murthy, G. K., Wehby, A. J., Schafer, M. L. \& Read, R. B. Jr. 1971. An assesment of some public health problems resulting from feeding poultry litter to animals. Microbiological and chemical parameters. Poult. Sci. 50: 874-881.

Møller, P. D. 1973. The influence of different carbohydrate sources on the utilization of urea nitrogen by lactating cows. 412 Beretn. Landøkon. Forsogslab. 204 p.

- \& Nemman-Sørensen, A. 1977. Economic and other consideration govering decisions on the advisability of incorporating additional and new sources of protein and nonprotein nitrogen into the diets of dairy cows. Symp. Recent developments in the use of new sources of protein, essential amino acids and non-protein nitrogen with special reference to ruminants. FAO, AGRI/SEM 7. Mimeogr. 21 p.

MÄкıNEN, S. 1972. Aspects of the nitrogen metabolism and nutritional status of urea-fed dairy cattle. Ann. Acad. Sci. Fenn. Ser A II. 165, 67 p.

Nesherm, M. C. 1972. Evaluation of dehydrated poultry manure as a potential poultry feed ingredient. Animal Waste Conf. 1972, Cornell Univ. p. 301-309.

Noland, R. P., Ford, B. F. \& Ray, M. L. 1955. The use of ground chicken litter as a source of nitrogen for gestalting-lactating ewes and fattening steers. J. Anim. Sci. 14: $860-865$.

NÄsı, M. 1975. Kananlanta nautakarjan valkuaisrehuna. Kehittyvä Maatalous 26: $39-49$.

- 1976. Kananlannan hyödyntäminen kotieläinten rehuna ja mikrobifermentaation avulla. (The use of dried poultry manure as animal feed and by microbial fermentation). Lic. thesis, Univ. of Helsinki, Dep. Anim. Husb. 112 p.

- , Saloniemi, H. \& Kallela, K. 1978 a. Dehydrated mink manure as a protein source for growing pigs. Acta vet. scand. 19: 73-83.

- , Saloniemi, H. \& Kallela, K. 1978 b. Hematological and blood chemical data of pigs fed various amounts of mink manure. Acta vet. scand. 19: 84-92.

O'Dell, B. L., Woods, W. D., Laerdal, O. A., Jaffary, A. M. \& Savage, J. E. 1960. Distribution of the major nitrogenous compounds and amino acids in chicken urine. Poult. Sci. 39: $426-432$.

Oliphant, J. M. 1973. Dried poultry waste and intensive beef production. Br. Soc. Anim. Prod. 80: 515-518.

- 1974. Feeding dried poultry waste for intensive beef production. Anim. Prod. 18: $211-217$.

OltJen, R. R. \& Dinius, D. A. 1976. Processed poultry waste compared with uric acid, sodium urate, urea and biuret as nitrogen supplements for beef cattle fed forage diets. J. Anim. Sci. 43: 201-208.

- , Dinius, R. A., Poos, M. I. \& Wrlliams, E. E. 1972. Na-urate, $25 \%$ urate and uric acid as NPN sources for beef cattle. J. Anim. Sci. 35:272.

- , Gutierrez, J., Lehman, R. P. \& Davies, R. E. 1966. Rumen chemical and microbial characteristics of steers fed a purified and a natural diet. J. Anim. Sci. 25: 521 - 526.

- , Slyter, L. L., Kozak, A. S. \& Williams, E. E. Jr. 1968. Evaluation of urea, biuret, urea phosphate and uric acid as NPN sources for cattle. J. Nutr. 94: 193-202. 
Ørskov, E. R. 1977. Nitrogen digestion and utilization by young and lactating ruminants. Wld Rev. Nutr. Diet. 26: 225-257.

Paloheimo, L. 1969. Weender Analyse. Handb. Tierernährung I: 164-171. Hamburg.

PARIGI-BINI, R. 1969. Utilization of pure dried poultry litter Toplan in feeding sheep. Alimentz. anim. 13: 277-281. (Ref. Nutr, Abstr. \& Rev. 40:660).

Parker, M. B., Perkins, H. F. \& Fuller, H. L. 1959. Nitrogen, phosphorus and potassium content of poultry manure and some factors influencing its composition. Poult. Sci. 38: $1154-1158$.

Payne, J. M., Dew, S. M., Manston, R. \& Faulks, M. 1970. The use of metabolic profile test in dairy herds. Vet. Rec. 87: $150-158$.

Perez-Aleman, S., Dempster, D. C., English, P. R. \& Topps, J. H. 1971. A note on dried poultry manure in the diet of the growing pig. Anim. Prod. 13:361-364.

Perkins, H. F. \& PARKer, M. P. 1971. Chemical composition of broiler and hen manure. Res. Bull. Univ. of Georgia, 90:1-17.

Platz, S. 1975. Hygienisierung und Verwertungsmöglichkeit von Geflügelkot und -einstreu eine Literaturübersicht. Arch. Geflügelk. 39: 158-166.

Polin, D., Varghese, S., Neff, M., Gomez, M., Flegal, C. J. \& Zindel, H. C. 1971. The metabolizable energy value for dried poultry waste. Mich. St. Univ. Agric. Exp. Sta. Res. Rep. 152: $32-44$.

Poppe, S. \& GRUGEL, F. 1971. Untersuchungen über Einsatzmöglichkeiten von getrocknetem Hühnerkot bei Wiederkäuern. Tierzucht 25: 307-309.

Praetorius, E. \& Poulsen, H. 1953. Enzymatic determination of uric acid with detailed directions. Scand. J. Clin. Lab. Invest. 5: 273.

Pryor, W. J. \& Connor, J. K. 1964. A note on the utilization by chickens of energy from faeces. Poult. Sci. 43: $833-834$.

Quisenberry, J. H. \& Bradley, J. W. 1969. Nutrient recyeling by laying hens. Feedstuffs $41(5): 19$.

Refsgaard-Andersen, H., Sørensen, M. \& LyckkeaA, J. 1976. Anvendelse af tørret fjerkraegødning son foder i kødproduktionen. 443. Beret. Stat. Husdyrbr. fors. $32 \mathrm{p}$.

ReINhold, J. G. 1953. Total protein, albumin, and globulin. Standard Methods Clin. Chem. 1: 88-97. New York.

Robertson, J. B., Coppock, C. E., Noller, C. H., Wheeler, W. E. \& VanSoest, P. J. 1974. Regression of digestibility on intake in lactating dairy cows. J. Dairy Sci. 57:622.

RofFler, R. E. \& SATter, L. D. 1975. Relationship between ruminal ammonia and nonprotein nitrogen utilization by ruminants. II. Application of published evidence to the development of a theoretical model for predicting nonprotein nitrogen utilization. J. Dairy Sci. 58: 1889-1898.

- , Schwab, C. C. \& SATter, L. D. 1976. Relationship between ruminal ammonia and nonprotein nitrogen utilization by ruminants. Influence of intraruminal urea infusion on ruminal ammonia concentration. J. Dairy Sci. 59: 80-84.

Rowlands, G. J. \& Manston, R. 1976. The potential uses of metabolic profiles in the management and selection of cattle for milk and beef production. Livest. Prod. Sci. 3: $239-256$.

- , Manston, R., Росокc, R. M. \& Dew, S. M. 1975. Relationship between stage of lactation and pregnancy and blood composition in a herd of dairy cows and the influences of seasonal changes in management on these relationships. J. Dairy Res. 42: $349-362$.

Roy, J. H. B., Balch, C. C., Miller, E. L., Ørskov, E. R. \& Smith, R. H. 1977. Calculation of the N-requirement for ruminants from nitrogen metabolism studies. Protein metabolism and nutrition, EAAP Publ. 22: 126-129.

Ruhland, H. 1968. Möglichkeiten der Verwertung von Geflügelkot. Tierzucht 22: 420-422.

Rusnak, J. J., Long, T. A. \& KING, T. B. 1966. Hydrolysed poultry waste as a feed for cattle. J. Anim. Sci. 25: 909.

SALO, M-L. 1965. Determination of carbohydrate fractions in animal foods and faeces. Acta Agr. Fenn. 105: 1-102.

- , SUvitie, M. \& NäSI, M. 1975. Kuivatun kanansonnan energia-, valkuais- ja kivennäisarvo märehtijöillä. J. Scient. Agric. Soc. Finl. 47:462-468. 
SAtTer, L. D. \& Roffler, R. E. 1975. Nitrogen requirement and utilization in dairy cattle. J. Dairy Sci. 58: 1219-1235.

- \& Roffler, R. E. 1977 a. Calculating requirements for protein and nonprotein nitrogen by ruminants. Protein metabolism and nutrition. EAAP Publ. 22: 133-136.

- \& ROFFLER, R. E. 1977 b. Influence of nitrogen and carbohydrate inputs on rumen fermentation. Haresign, W. \& Lewis, D. (Ed.). Recent advances in animal nutrition 1977 , p. $25-49$.

- \& Slyter, L. L. 1974. Effects of ammonia concentration on ruminal microbial protein production in vitro. Br. J. Nutr. 32: 199-208.

Schefferle, H. E. 1965. The microbiology of built up poultry litter. J. appl. Bact. 28: 403411 .

Shannon, D. W. F., Blatr, R. \& LeE, D. J. W. 1973. Chemical and bacteriological composition and metabolisable energy value of eight samples of dried poultry waste produced in the United Kingdom. 4th Europ. Poult. Conf., London, p. 487-494.

- \& BRown, W. O. 1969. Losses of energy and nitrogen on drying poultry excreta. Poult. Sci. 48: $41-43$.

Sheppard, C. C., Flegal, C. J., Dorn, D. \& Dale, J. L. 1971. The relationship of drying temperature to total crude protein in dried poultry waste. Mich. St. Univ. Agric. Exp. Sta. Res. Rep. 152: 12-16.

Silva, L. A., Vanhorn, H. H., Olaloku, E. A., Willcox, C. J. \& Harris, B. Jr. 1976. Complete rations for dairy cattle. VII. Dired poultry waste for lactating cows. J. Dairy Sci. 59: 2071-2076.

Singh, Y. K. \& Anthony, W. B. 1968. Yeast production in manure solubles. J. Anim. Sci. 27: 1136.

Sloan, D. R. \& Harms, R. H. 1973. The effect of incorporating hen manure into the diet of young chicks. Poult. Sci. 52: $803-805$.

Slyter, L. L., Oltjen, R. R., Kern, D. L. \& Weaver, J. M. 1968. Microbial species including ureolytic bacteria from the rumen of cattle fed purifies diets. J. Nutr. 94: 185 -192 .

Sмгтн, L. W. 1974. Dehydrated poultry excreta as a crude protein supplement for ruminants. World anim. rev. FAO. 11: 6-11.

- \& Calvert, C. C. 1972. Dehydrated poultry waste in rations for sheep. J. Anim. Sci. $35: 275$.

- \& CAlvert, C. C. 1976. Dehydrated broiler excreta versus soybean meal as nitrogen supplements for sheep. J. Anim. Sci. 43: 1286-1292.

- , Calvert, C. C. \& Menlar, J. R. 1973. Dehydrated poultry manure as a protein supplement for sheep. Proc. Md. Nutr. Conf. p. 35.

- \& Fries, C. F. 1973. Dehydrated poultry manure as a crude protein supplement for lactating cows. J. Dairy Sci. 56: 668 .

- , Fries, G. F. \& Weinland, B. T. 1976. Poultry excreta containing polychlorinated biphenyls as a protein supplement for lactating cows. J. Dairy Sci. 59:465-474.

- \& WheEler, W. E. 1979. Nutritional and economical value of animal excreta. J. Anim. Sci. 48: 144-156.

Smith, O. B., Fox, C. A., Mowat, D. N., Macleod, G. K. \& Morgan, E. T. Jr. 1978 a. A laboratory evaluation of organic acids and formaldehyde as preservatives for wet cage layer excreta intended for recycling by feeding to livestock. Can. J. Anim. Sci. 58: $209-216$.

- , Macleod, G. K., Mowat, D. N., Fox, C. A. \& Morgan, E. T. Jr. 1978 b. Performance and health of calves fed wet caged layer excreta as a protein supplement. J. Anim. Sci. 47: 833-842.

Smith, J. W. \& VAndersall, J. H. 1973. Response of the blood proteins to protein intake of dairy cows. Proc. Md. Nutr. Conf. p. 30.

Steel, R. G. \& Torrie, J. H. 1960. Principles and procedures of statistics. 481 p. New York. SteINeck, S. 1974. Inneholl av växtnäring i olika stallgödsellslag. NJF 56 (1): $58-59$.

Somogyi, M. 1945. A new reagent for the determination of sugars. J. Biol. Chem. 160: $61-68$.

Southwell, B. L., Hale, O. M. \& McCormick, W. C. 1958. Poultry house litter as a protein supplement in steer fattening rations. Georgia Agr. Exp. Sta. Mimeo. Ser. N. S1, 55. (Ref. Fontenot, P. J. \& Webb, K. E. Jr, 1974). 
Surbrook, T, C., Sheppard, C. C., Boyd, J. S., Zindel, H. C. \& Flegal, C. J. 1971. Drying poultry waste. Livestock Waste Management and Pollution Abatement. Proc. Int. Symp. on Livestock Waste ASAE Publ. Proc. 271:348-350. Columbus, Ohio.

Suttle, N. F., Munro, C. S. \& Field, A. C. 1978. The accumulation of copper in the liver of lambs on diets containing dried poultry waste. Anim. Prod. 26:39-45.

Swenson, M. J. 1970. Physiologic properties, cellular and chemical constituents of blood. Duke's physiology of domestic animals. Cornell Univ. Press.

Sykes, A. H. 1971. Physiology and biochemistry of the domestic fowl. Bell, D. J. \& Freeman, B. M. 1481 p. London, New York.

Syretr, R. F. 1977. Microbiological aspects of recycling manure. World's Poult. Sci. J. 33: $198-215$

Syrjälä, L., Saloniemi, H. \& Laalahti, L. 1976. Composition and volume of the rumen microbiota of sheep fed on grass silage with different sucrose, starch and cellulose supplements. J. Scient. Agric. Soc. Finl. 48: 138-153.

- , Syvãoja, E.-L. \& Boman, M. 1978. Utilization of untreated and formaldehyde treated skimmilk powder and skimmilk powder barley pellets by ruminants. J. Scient. Agric. Soc. Finl. 50: 166-176.

TAUSSKy, H. H. \& SHORR, E. 1953. A microcolorimetric method for the determination of inorganic phosphorus. J. Biol. Chem. 202: 675-685.

TAYLOR, J. C. 1971. Regulatory aspects of recycled livestock and poultry wastes. Livestock Waste Management and Pollution Abatement. Proc. Int. Symp. on Livestock Waste. ASAE Publ. Proc. 271: 291-292. Columbus, Ohio.

- . Gable, D. A., Graber, G. \& Lucas, E. W. 1974. Health criteria for processed wastes. Feder. Proc. 33: 1945-1946.

- \& GEYER, R. E. 1979. Requlatory considerations in the use of animal waste as feed ingredient. J. Anim. Sci. 48: 218-222.

Terpstra, K. \& de Hart, N. 1974. The estimation of urinary nitrogen and faecal nitrogen in poultry excreta. Z. Tierphysiol., Tierernährg. und Futtermittelk. 32: 306-320.

Тномаs, J. W. 1970. Acceptability and digestibility of poultry and dairy wastes by sheep. Mich. St. Univ. Agric. Exp. Sta. Res. Rep. 117: 42-44.

- , YU, YU, Tinnimit, P \& Zindel, H. C. 1972. Dehydrated poultry waste as a feed for milking cows and growing sheeps. J. Dairy Sci. 55: 1261-1265.

- \& Zindel, H. C. 1971. Feeding dehydrated poultry waste to dairy cows. Mich. St. Univ. Agric. Exp. Sta. Res. Rep. 152: 8-11.

Tinnimit, P., McCuggey, K., YU, Yu \& Thomas, J. W. 1972. Dried animal waste as a protein supplement for sheep. J. Anim. Sci. 35: 431-435.

Treacher, R. J., Little, W., Collis, K. A. \& Stark, A. J. 1976. The influence of dietary protein intake on milk production and blood composition of high-yielding dairy cows. J. Dairy Res. 43:357-369.

TǗLLER, R. 1972. Kotverwertung in der Tierfütterung. Dt. Geflügelwirtsch. $-24: 73-75$.

UNShelm, J. 1969. Individual diurnal and time of day changes in the blood constituents of cattle. 6. Behavior of serum total protein concentration and its components. Zentralabt. Vet.-Med. 16 A: 808.

WARden, W. K. 1963. Handling and disposing of poultry manure. Mich. State Univ. Ext. Folder F 323.

VARGHESE, S. K. \& F FEGAL, C. J. 1972. The effects of continuous recycling dried poultry waste in laying hen diets on trace minerals found in various tissues. Poult. Sci. 51:1882.

WebB, K. E. \& Fontenot, J. P. 1975. Medical drug residues in broiler litter and tissues from cattle fed litter. J. Anim. 41: 1212-1217.

- , Phillips, W. A., Liebke, K. G., Harmon, B. W. \& Fontenot, J. P. 1973. Different levels of broiler litter in ewe eations. J. Anim. Sci. 36: 218.

Wehunt, K. E., Fuller, H. L. \& Edwards, H. M., Jr. 1960. The nutritional value of hydrolyzed poultry manure for broiler chickens. Poult. Sci. 39: 1057-1063.

Wilkinson, S. R. 1979. Plant nutrient value and economic value of animal waste. J. Anim. Sci. $48: 121-133$.

Virtanen, A. I. 1966. Milk production of cows on a protein free feed. Science 153: 1603-1614.

- 1971. Protein requirements of dairy cattle - artificial nitrogen sources and milk production. Milchwissenschaft 26: 129-138. 
Wittenburg, H. \& Chudy, A. 1967. Zur Analytik von Hühnerexkrementen. Arch. Geflügelk. Kleintierk. 16: $221-228$.

Vogr, H. 1973. Geflügeltrockenkot im Legehennenfutter. Arch. Geflügelk. 37: $141-147$.

Wohlt, J. E., Clark, J. H. \& Blaisdell, F. S. 1978. Nutritional value of urea versus preformed protein for ruminants. II. Nitrogen utilization by dairy cows fed corn based diets containing supplemental nitrogen from urea and/or soybean meal. J. Dairy Sci. 61: $916-931$.

Vuori, A. T. \& NÄsI, J. M. 1977. Fermentation of poultry manure for poultry diets. Br. Poult. Sci. 18: 255-262.

Young, R. J. \& Nesherm, M. C. 1972. Dehydrated poultry waste as a feed ingredient. Proc. 1972. Cornell Nutr. Conf. for Feed Manuf. p. 46-55.

Yoshida, M. \& Hosнi, H. 1968. Nutritional value of poultry manure. Jap. Poult. Sci. 5: $37-39$.

Yosнок, W. \& Bear, F. E. 1943. Poultry manure, its preservation, deodorization and disinfection. N. J. Agr. Expt. Sta. Bull. 707.

Zindel, H. C. 1970. Bacteriological procedures. Mich. St. Univ. Agric. Exp. Sta. Res. Rep. 117: $45-46$.

Zorita, E., Rodrigues, G. J., Santos, J., Burbrigs, S. \& Bejero, F. K. O. 1967. Poultry droppings for feeding ruminants 3 . Trials with milking ewes. Nutrition animal. Madrid. 5: 95 .

\title{
SELOSTUS
}

\section{Kananlanta lypsylehmien rehuna}

\author{
Matri Näsı
}

Helsingin yliopisto, kotieläintieteen laitos

Suoritetussa tutkimuksessa selvitettiin kuivatun kananlannan käyttöä runsastuottoisten lypsylehmien valkuaislähteenä vertaamalla sitä soijaan ja ureaan väkirehuvaltaisella ruokinnalla. Edelleen tutkittiin kananlantaruokinnan vaikutusta rehuyhdistelmän sulavuuteen, veriarvoihin ja pötsifermentaatioon.

Kahtena peräkkäisenä vuonna suoritettiin ruokintakoe 18 runsastuottoisella lehmällä, jotka oli jaettu kolmeen mahdollisimman samanarvoiseen ryhmäan. Perusrehuna oli heinä ja väkirehuseosta annettiin tuotostason mukaisesti. Eri ryhmien väkirehuseoksen valkuaislisäyksenä oli $20 \%$ kuivattua kananlantaa, $10 \%$ soijarouhetta ja $1.5 \%$ ureaa. Vertailukausi oli ensimmäisesså kokeessa 13 viikkoa ja toisessa kokeessa 15 viikkoa. Kokeissa määritettiin rehujen maittavuus, rehunkulutus ja rehun hyväksikäyttō, maitotuotos ja maidon koostumus sekä seurattiin eläinten terveydentilaa.

Kokeessa käytetyn kananlannan energia-arvo oli alhainen, $0.34-0.35 \mathrm{ry} / \mathrm{kg}$ ka, mutta valkuaisväkevyys oli korkea, $400-709 \mathrm{~g} \mathbf{s r v} / \mathrm{kg}$.Virtsahappoa oli kokeessa 1 käytetyssä kananlannassa keskimäärin $9.5 \%$, kun taas kokeessa 2 huomattavasti vähemmän, $1.2 \%$ ka. Kananlannan tuhkapitoisuus oli korkea sekä kivennäiskoostumus monipuolinen; kalsiumia 5.6$6.9 \%$ ja fosforia $1.8-2.6 \%$. Kananlantaa sisältävän väkirehuseoksen energia-arvo oli $13 \%$ alempi kuin soijaa tai ureaa sisältävăn seoksen. Kananlantaa sisältävän väkirehuseoksen syönti ilmaistuna prosentteina tarjotusta oli merkitsevästi alhaisempi kuin toisten seosten, ja tästä johtuen kananlantaryhmän energiavajaus oli suurempi kuin toisten varsinkin kokeen alkupuolella. Kokeen alussa syōnti oli alhaisinta, johtuen suurista väkirehumääristä. Keskimääräinen kananlannan syönti oli 1.9 ja 2.0 kg päivässä lehmää kohti kokeessa 1 ja 2 . Vastaavasti virtsahapon syönti oli 186 kg ja 24 g päivässä. Kananlannasta tulevan sulavan raakavalkuaisen osuus oli $29.0 \%$ ja $19.0 \%$ kokonaismääräistä kokeessa 1 ja 2 . Urean saanti oli keskimäärin $140 \mathrm{~g}$ päivässä. Karkearehu-väkirehusuhde oli kokeessa $136 \%$ : $64 \%$ ja kokeessa $239 \%$ : $61 \%$. Energian ja valkuaisen saanti ei poikennut merkitsevästi ryhmien välillä. Kuiva-aineen 
syönti oli kokeessa 2 kananlantaa saaneella ryhmällä suurempi kuin soijaa ja ureaa saaneilla ryhmillä. Kananlantaryhmän lehmät saivat rehuista enemmän kuitua, mutta vähemmän sokeria kuin toiset ryhmät. Useimpia kivennäisiä kananlantaryhmän lehmät saivat enemmän johtuen kananlannan sisältämistä korkeista kivennäismääristä.

Eri rehuyhdistelmien kuiva-aineen sulavuudet olivat $69.9 \%, 72.0 \%$ ja $74.0 \%$ kananlantaa, soijaa ja ureaa sisältävillä seoksilla. Raakavalkuaisen sulavuudet olivat vastaavasti $72.3 \%$, $71.8 \%$ ja $75.9 \%$. Erot kananlanta- ja ureaseosten välillä olivat merkitseviä $(\mathrm{P}<0.05)$.

Eri ryhmien maitotuotosten tai maidon koostumuksen välillä ei ollut merkitseviä eroja. Maitotuotoksen lasku oli kokeessa 1 kananlantaryhmällä nopeampaa $(\mathrm{P}<0.05)$ kuin toisilla ryhmillä. Elopainon muutosten välillä ei ollut merkitseviä eroja. Rehun hyväksikäytōssä eri ryhmien välillä kokeen 1 osalta ei ollut eroja, mutta kokeessa 2 kananlantaryhmä kulutti vähemmän energiaa ja sulavaa raakavalkuaista tuotettua maitokiloa kohti.

Verianalyysien perusteella selvitettiin lehmien aineenvaihdunnan muutoksia ja ravitsemuksellista tilaa. Lisäksi selvitettiin kananlannan typellisten yhdisteiden ja kivennäisaineiden käyttökelpoisuutta. Saaduista tuloksista voidaan todeta, ettei kananlannan syöttäminen kohtuullisella tasolla $(10-40 \%$ väkirehuseoksesta) aiheuttanut haitallisia muutoksia lehmien aineenvaihduntaan tai terveydellisen tilaan ja saadut arvot vastasivat normaaliarvoja.

Pötsifistelöidyillä lehmillä tutkittiin kananlannan typellisten yhdisteiden hajoamista pötsissä sekä kananlannan vaikutusta pötsifermentaatioon. Kokeessa käytettiin soijaa vertailuvalkuaisena ja kananlannan määrä vaihteli 10,20 ja $40 \%$ väkirehuseoksesta. Pötsinesteen ammoniakin määrä nousi kananlannan määrän noustessa. Etikkahapon osuus lisääntyi ja propionihapon ja voihapon osuudet vähentyivät rasvahappojen kokonaismäärästä, kun kananlannan määrä lisääntyi. Pötsin alkueläinten määrä oli suurempi ja bakteerien määrä pienempi kananlantaruokinnalla verrattuna soijaan.

Suoritetuissa ruokintakokeissa todettiin runsastuottoisten lehmien pystyvän käyttämään hyväkseen kananlantaa valkuaislähteenä lähes yhtä hyvin kuin soijaa ja paremmin kuin ureaa. Kananlannan typellisten yhdisteiden tehokkaan hyväksikäytön edellytyksenä on riittävä energiansaanti, johon päästään runsaalla väkirehuruokinnalla. 
Appendix 1. Chemical composition of dehydrated poultry manure (DPM), poultry litter and broiler litter.

\begin{tabular}{|c|c|c|c|c|c|}
\hline $\begin{array}{l}\text { Camposition of } \\
\text { dry matter, \% }\end{array}$ & $\begin{array}{l}\text { Poult } \\
\text { mean }\end{array}$ & $\begin{array}{l}\text { manure } \\
\text { range }\end{array}$ & $\begin{array}{l}\text { Por } \\
\text { mean }\end{array}$ & $\begin{array}{l}\text { ry litter } \\
\text { range }\end{array}$ & $\begin{array}{c}\text { Broiler } \\
\text { litter } \\
\text { mean }\end{array}$ \\
\hline Crude protein ............. & 28.3 & $15.2-42.1$ & 25.3 & $19.6-32.3$ & 43.9 \\
\hline True protein .............. & 10.8 & $8.1-12.9$ & 16.6 & $12.9-21.8$ & 24.8 \\
\hline Crude fibre..$\ldots \ldots \ldots \ldots$ & 13.1 & $10.0-19.3$ & 18.7 & $11.2-23.9$ & 16.8 \\
\hline Ether extract ............. & 2.0 & $0.0-3.0$ & 2.3 & $1.7-3.1$ & 3.3 \\
\hline NFE $\ldots \ldots \ldots \ldots \ldots \ldots \ldots \ldots \ldots$ & 31.7 & $25.1-45.1$ & & & 29.5 \\
\hline Ash ............................ & 25.8 & $18.8-40.8$ & 14.1 & $13.4-14.9$ & 25.8 \\
\hline Uric acid .................. & 7.1 & $2.8-12.7$ & 8.5 & & \\
\hline Ammonia .................. & 0.7 & $0.4-1.2$ & & & \\
\hline Lignin & 6.6 & $5.7-7.4$ & 8.0 & & \\
\hline Calcium...$\ldots \ldots \ldots \ldots \ldots \ldots$ & 7.8 & $4.9-12.5$ & 2.5 & $1.8-3.2$ & 2.4 \\
\hline Phosporus ................. & 2.2 & $1.7-2.8$ & 1.6 & $1.2-2.5$ & 1.8 \\
\hline Magnesium ................. & 0.63 & $0.4-1.0$ & 0.42 & & 0.44 \\
\hline Sodium & 0.42 & $0.1-1.0$ & 1.77 & & 0.54 \\
\hline Potassium ................. & 1.37 & $0.8-2.1$ & 0.35 & $0.33-0.38$ & \\
\hline Iron & 0.2 & $0.01-0.4$ & 0.02 & & \\
\hline Copper ...................... & 0.006 & $0.003-0.01$ & 0.009 & & 0.009 \\
\hline Manganese ................ & 0.029 & $0.019-0.041$ & 0.028 & & \\
\hline 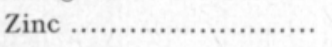 & 0.032 & $0.021-0.045$ & 0.022 & & \\
\hline Alanine $. . . \ldots \ldots \ldots \ldots \ldots . . . . . . . . .$. & 0.83 & $0.61-1.06$ & 0.88 & & 0.92 \\
\hline Arginine $\ldots \ldots \ldots \ldots \ldots \ldots \ldots$ & 0.48 & $0.38-0.61$ & 0.51 & & 0.66 \\
\hline Aapartic acid ........... & 1.03 & $1.22-0.71$ & 1.22 & & 1.29 \\
\hline Cystine ...................... & 0.27 & $0.18-0.53$ & 0.09 & & 0.41 \\
\hline Glutamic acid …........ & 1.38 & $1.66-1.11$ & 2.19 & & 2.03 \\
\hline 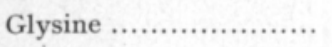 & 1.18 & $0.66-1.91$ & 2.14 & & 2.35 \\
\hline Histidine ................. & 0.24 & $0.21-0.30$ & 0.24 & & 0.27 \\
\hline Isoleucine $\ldots \ldots \ldots \ldots \ldots \ldots$ & 0.43 & $0.36-0.46$ & 0.64 & & 0.55 \\
\hline Leucine ..................... & 0.70 & $0.55-0.76$ & 1.00 & & 0.98 \\
\hline Lysine ...................... & 0.49 & $0.39-0.60$ & 0.57 & & 0.65 \\
\hline Methionine ................ & 0.15 & $0.12-0.21$ & 0.13 & & 0.19 \\
\hline Phenylalanine ............. & 0.39 & $0.35-0.45$ & 0.54 & & 0.59 \\
\hline Proline ......................... & 0.47 & & 0.93 & & 0.66 \\
\hline Serine $\ldots \ldots \ldots \ldots \ldots \ldots \ldots \ldots \ldots$ & 0.50 & $0.38-0.62$ & 0.57 & & 0.78 \\
\hline Threonine .................. & 0.46 & $0.35-0.53$ & 0.57 & & 0.70 \\
\hline Tyrosine ..................... & 0.30 & $0.27-0.34$ & 0.33 & & 0.47 \\
\hline Valine ........................ & 0.67 & $0.46-0.83$ & 0.82 & & 0.71 \\
\hline
\end{tabular}

Based on the data of

Wehunt et al. (1960), Brugman et al. (1964), Bhattacharya and Fontenot (1965), QuisenBerRy and BRADLEY (1969), Flegal and Zindel (1970), Fontenot et al. (1971 b), Kiefer (1971), Perez-Aleman et al. (1971), Polin et al. (1971), Poppe and Grugel (1971), Biely et al. (1972), Lee and Blajr (1972), Nesheim (1972), Blair and Knight (1972 a), Shannon et al. (1973), Vogt (1973), Harnisch (1974), McNab et al. (1974), Bhattacharya and Taylor (1975), SALo et al. (1975), Näsi (1976), Vuori and NÃsI (1977), Evans et al. (1978 a). 
Appendix. 2. Compilation of results of practical feeding experiments with dehydrated poultry manure to dairy cows.

\begin{tabular}{|c|c|c|c|c|c|c|c|}
\hline & Period of & Percent of & & ilk yield, & & & \\
\hline $\begin{array}{l}\text { perimental } \\
\text { cows }\end{array}$ & $\begin{array}{l}\text { experiment } \\
\text { week }\end{array}$ & $\begin{array}{l}\text { DPM in } \\
\text { concentrate }\end{array}$ & $\begin{array}{l}\text { Control } \\
\text { ration }\end{array}$ & DPM & NPN & $\begin{array}{l}\text { Deficient } \\
\text { ration }\end{array}$ & Reference \\
\hline 35 & 12 & $30 \%$ & 21.1 & 21.7 & 22.4 & 19.5 & Thomas and ZiNDEL (1971) \\
\hline 30 & 12 & $30,2 \%$ & 19.6 & 20.6 & 21.5 & 18.4 & Tномаs et al. (1972) \\
\hline 22 & 15 & $39 \%$ & 16.0 & 16.2 & & & Claesson and Ahlström (1974) \\
\hline 23 & 15 & $40 \%$ & 15.8 & 15.6 & & & AHLstRöм (1974) \\
\hline 14 & & $20 \%$ & 11.4 & 10.7 & & & KNEALE and Garstang (1975) \\
\hline 16 & & $20 \%$ & 15.3 & 16.0 & & 15.3 & 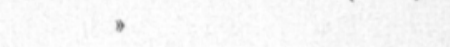 \\
\hline 48 & & $10 ; 20 \%$ & 11.7 & $12.4 ; 11.6$ & & 11.7 & , \\
\hline 24 & 4 & $10 \%$ & 21.2 & 20.6 & & & SiLvA et al. (1976) \\
\hline & & $20 ; 30 \%$ & & $17 ; 113,9$ & & & . \\
\hline 24 & 13 & $32 \%$ & 17.1 & 15.4 & & & Sмiтн et al. (1976) \\
\hline 18 & 8 & $20 ; 40 \%$ & 21.3 & $21.3 ; 22.6$ & & & KrISTENSEN et al. (1976) \\
\hline 45 & 7 & $20 ; 40 \%$ & 20.2 & $19.1 ; 19.0$ & & & , \\
\hline 63 & 6 & $20 ; 40 \%$ & 18.5 & $18.6 ; 18.0$ & & & , \\
\hline 24 & 32 & $17.2 ; 26.0 \%$ & 17.2 & $18.0 ; 16.7$ & 15.1 & & Calvert and King (1977) \\
\hline
\end{tabular}


है

क⿺

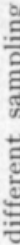

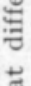

$\stackrel{\Xi}{\Xi}$

ह

른

ฉ.

$\Phi$

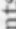

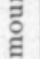

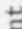

ఫ

$\sum^{\infty}$

톤 응

产究客

$$
-1 \times
$$

$$
i^{i k}
$$

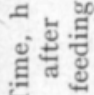

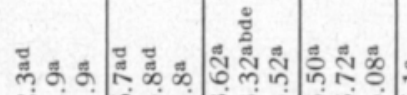

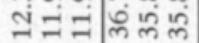

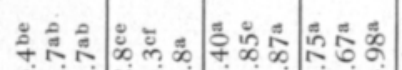

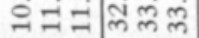
$\exists \Xi \Xi$ लं लें

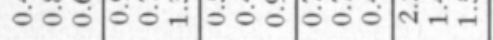

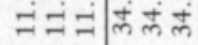

ल ल m in in + in

产空

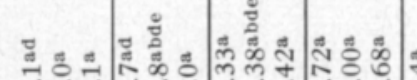

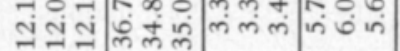
oro os

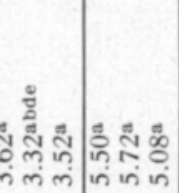

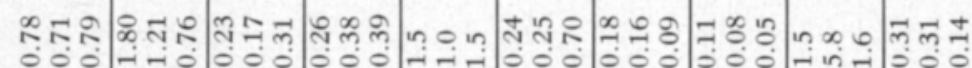

的实 in

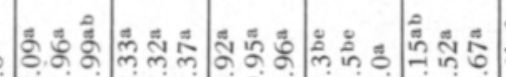

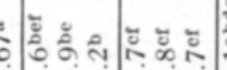

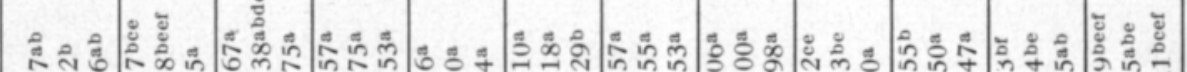

लंm

nicininis

프로원

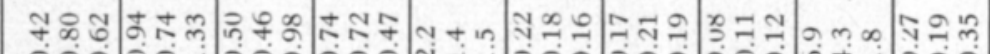

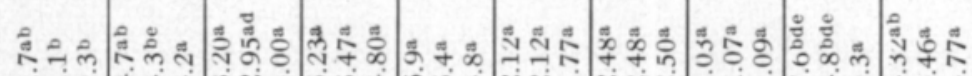

$\infty \operatorname{lin}_{\infty} \dot{0}$

ニ

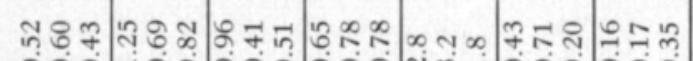

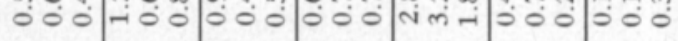

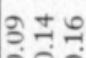

$\operatorname{man} 2$ 年去

+0 in

โุ

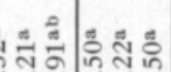

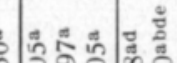
एक 폰

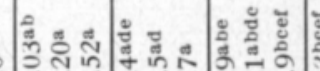

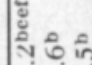

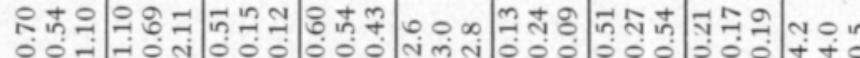

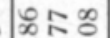

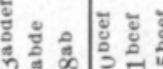

형용

$$
\text { (n) }
$$

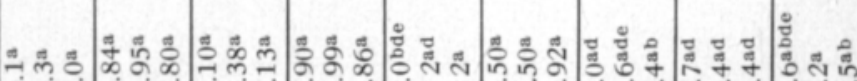
$\bowtie \infty$

$\stackrel{\infty}{\exists} \Xi \Xi$ ते
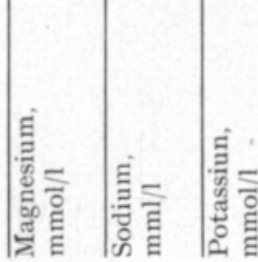
Appendix 4.

$\mathrm{pH}$, ammonia nitrogen and volatile fatty acids in the rumen fluid on different diets and different sampling times. Experiment 1.

\begin{tabular}{|c|c|c|c|c|c|c|c|c|c|c|c|c|}
\hline \multirow[b]{2}{*}{ Diets } & \multirow{2}{*}{$\begin{array}{l}\text { Time, h } \\
\text { after } \\
\text { feeding }\end{array}$} & \multirow[b]{2}{*}{$\mathrm{pH}$} & \multirow{2}{*}{$\begin{array}{c}\mathrm{NH}_{3}-\mathrm{N} \\
\mathrm{mg} / \\
100 \mathrm{ml}\end{array}$} & \multirow{2}{*}{$\begin{array}{l}\text { Total } \\
\text { VFA } \\
\mathrm{mmol} / 1\end{array}$} & \multirow[b]{2}{*}{$\begin{array}{c}\text { Acetic } \\
\text { acid }\end{array}$} & \multicolumn{3}{|c|}{ Molar \% } & \multicolumn{4}{|c|}{ Molar ratio } \\
\hline & & & & & & $\begin{array}{l}\text { Propionic } \\
\text { acid }\end{array}$ & $\begin{array}{l}\text { Butyric } \\
\text { acid }\end{array}$ & $\begin{array}{l}\text { cValeric } \\
\text { acid }\end{array}$ & $\begin{array}{c}\text { ic Iso- } \\
\text { valeric } \\
\text { acid }\end{array}$ & $\begin{array}{l}\text { Acetic/ } \\
\text { propionic }\end{array}$ & $\begin{array}{l}\text { Acetic/ } \\
\text { butyric }\end{array}$ & $\begin{array}{c}\text { Propionic/ } \\
\text { butyric }\end{array}$ \\
\hline 1 & 3 & $6.25^{\mathrm{a}}$ & $15.6^{\mathrm{ae}}$ & $127.9 \mathrm{ab}$ & $67.2^{\mathrm{a}}$ & $17.5^{\mathrm{a}}$ & $12.5^{\mathrm{a}}$ & $1.4^{\mathrm{a}}$ & $3.8^{\mathrm{a}}$ & $3.8^{\mathrm{a}}$ & $5.2^{\mathrm{a}}$ & $1.4^{\mathrm{a}}$ \\
\hline SBM $10 \%$ & 5 & $5.95^{\mathrm{b}}$ & $8.6^{d}$ & $133.3^{\mathrm{a}}$ & $66.7^{\mathrm{a}}$ & $17.8^{\mathrm{a}}$ & $13.1^{\mathrm{a}}$ & $1.2^{\mathrm{ab}}$ & $1.2^{\mathrm{a}}$ & $3.8^{\mathrm{a}}$ & $5.1^{\mathrm{a}}$ & $1.4^{\mathrm{a}}$ \\
\hline DPM $0 \%$ & 8 & $6.37 \mathrm{a}$ & $13.1^{\text {be }}$ & $119.2^{\mathrm{b}}$ & $67.2^{\mathrm{a}}$ & $18.1^{\mathrm{a}}$ & $12.3^{\mathrm{a}}$ & $1.0^{\mathrm{bd}}$ & $1.4^{\mathrm{a}}$ & $3.7^{\mathrm{a}}$ & $5.5^{\mathrm{a}}$ & $1.4^{\mathrm{a}}$ \\
\hline 2 & 3 & $6.10^{\mathrm{a}}$ & $26.2^{e}$ & $108.7^{\mathrm{a}}$ & $69.6^{\mathrm{a}}$ & $17.3^{\mathrm{a}}$ & $10.5^{\mathrm{a}}$ & $1.8^{\mathrm{ae}}$ & $0.8^{\mathrm{a}}$ & $4.1^{\mathrm{a}}$ & $6.7^{\mathrm{a}}$ & $1.7^{\mathrm{a}}$ \\
\hline SBM $5 \%$ & 5 & $5.89^{\mathrm{b}}$ & $18,0^{\mathrm{ad}}$ & $120.0^{\mathrm{a}}$ & $69.8^{\mathrm{a}}$ & $15.5^{\mathrm{a}}$ & $12.7^{\mathrm{a}}$ & $1.5^{\text {be }}$ & $0.6^{\mathrm{a}}$ & $4.6^{\mathrm{a}}$ & $5.9^{\mathrm{a}}$ & $1.3^{\mathrm{a}}$ \\
\hline DPM $10 \%$ & 8 & $6.33^{\mathrm{a}}$ & $15.0^{\mathrm{bd}}$ & $111.9^{\mathrm{a}}$ & $71.4^{\mathrm{a}}$ & $15.8^{\mathrm{a}}$ & $11.1^{\mathrm{a}}$ & $0.9^{\mathrm{d}}$ & $0.8^{\mathrm{a}}$ & $4.6^{\mathrm{a}}$ & $6.4^{\mathrm{a}}$ & $1.4^{\mathrm{a}}$ \\
\hline 3 & 3 & $6.29^{\mathrm{a}}$ & $35.9^{d}$ & $119.0^{\mathrm{a}}$ & $67.4^{\mathrm{a}}$ & $17.2^{\mathrm{a}}$ & $13.1^{\mathrm{a}}$ & $1.2^{\mathrm{a}}$ & $1.2^{\mathrm{a}}$ & $4.0^{\mathrm{a}}$ & $5.2^{\mathrm{a}}$ & $1.3^{\mathrm{a}}$ \\
\hline SBM $0 \%$ & 5 & $6.25^{\mathrm{a}}$ & $16.3^{e}$ & $124.3^{\mathrm{a}}$ & $70.0^{\mathrm{b}}$ & $16.6^{\mathrm{a}}$ & $11.9^{\mathrm{a}}$ & $0.8^{\mathrm{a}}$ & $0.7 \mathrm{a}$ & $4.3^{\mathrm{a}}$ & $5.9^{\mathrm{b}}$ & $1.4^{\mathrm{a}}$ \\
\hline DPM $20 \%$ & 8 & $6.13^{\mathrm{a}}$ & $8.8^{f}$ & $126.8^{\mathrm{a}}$ & $68.2^{\mathrm{a}}$ & $17.5^{\mathrm{a}}$ & $12.7^{\mathrm{a}}$ & $0.8^{\mathrm{a}}$ & $0.9^{\mathrm{a}}$ & $3.9^{\mathrm{a}}$ & $5.4^{\mathrm{ab}}$ & $1.4^{\mathrm{a}}$ \\
\hline 4 & 3 & $6.47^{\mathrm{a}}$ & $35.7^{\mathrm{a}}$ & $115.3^{\mathrm{a}}$ & $68.1^{\mathrm{a}}$ & $18.8^{\mathrm{a}}$ & $11.5^{\mathrm{a}}$ & $1.0^{\mathrm{a}}$ & $0.6^{\mathrm{a}}$ & $3.6^{\mathrm{a}}$ & $6.0^{\mathrm{a}}$ & $1.7 \mathrm{a}$ \\
\hline SBM $0 \%$ & 5 & $6.39^{\mathrm{a}}$ & $23.1^{\mathrm{a}}$ & $115.1^{\mathrm{a}}$ & $69.2^{\mathrm{a}}$ & $17.7^{\mathrm{a}}$ & $11.3^{\mathrm{a}}$ & $1.0^{\mathrm{a}}$ & $0.8^{\mathrm{a}}$ & $3.9^{\mathrm{a}}$ & $6.2^{\mathrm{a}}$ & $1.6^{\mathrm{a}}$ \\
\hline DPM $40 \%$ & 8 & $6.48^{a}$ & $28.9^{\mathrm{a}}$ & $119.2^{\mathrm{a}}$ & $70.0^{\mathrm{a}}$ & $17.7^{a}$ & $11.0^{\mathrm{a}}$ & $0.6^{\mathrm{b}}$ & $0.7^{\mathrm{a}}$ & $4.0^{\mathrm{a}}$ & $6.4^{\mathrm{a}}$ & $1.6^{\mathrm{a}}$ \\
\hline 5 & 3 & $6.24^{\mathrm{a}}$ & $26.1^{e}$ & $109.5^{\mathrm{a}}$ & $68.7^{\mathrm{a}}$ & $15.8^{\mathrm{a}}$ & $13.6^{\mathrm{a}}$ & $1.2^{\mathrm{a}}$ & $0.8^{\mathrm{a}}$ & $4.5^{\mathrm{a}}$ & $5.1^{\mathrm{a}}$ & $1.2^{\mathrm{a}}$ \\
\hline SBM $10 \%$ & 5 & $6.21^{\mathrm{a}}$ & $10.9^{\mathrm{ad}}$ & $109.1^{\mathrm{a}}$ & $69.3^{\mathrm{a}}$ & $16.0^{\mathrm{a}}$ & $13.2^{\mathrm{a}}$ & $0.8^{b}$ & $0.7^{\mathrm{a}}$ & $4.4^{\mathrm{a}}$ & $5.2^{\mathrm{a}}$ & $1.2^{\mathrm{a}}$ \\
\hline DPM $0 \%$ & 8 & $6.20^{\mathrm{a}}$ & $8.1^{\text {bd }}$ & $119.2^{\mathrm{a}}$ & $70.3^{\mathrm{a}}$ & $15.7^{\mathrm{a}}$ & $12.5^{\mathrm{a}}$ & $0.6^{\mathrm{b}}$ & $0.9^{\mathrm{a}}$ & $4.6^{\mathrm{a}}$ & $5.6^{\mathrm{b}}$ & $1.3^{\mathrm{a}}$ \\
\hline
\end{tabular}

Appendix 5.

$\mathrm{pH}$, ammonia and volatile fatty acids in the rumen fluid on different diets and different sampling times. Experiment 2.

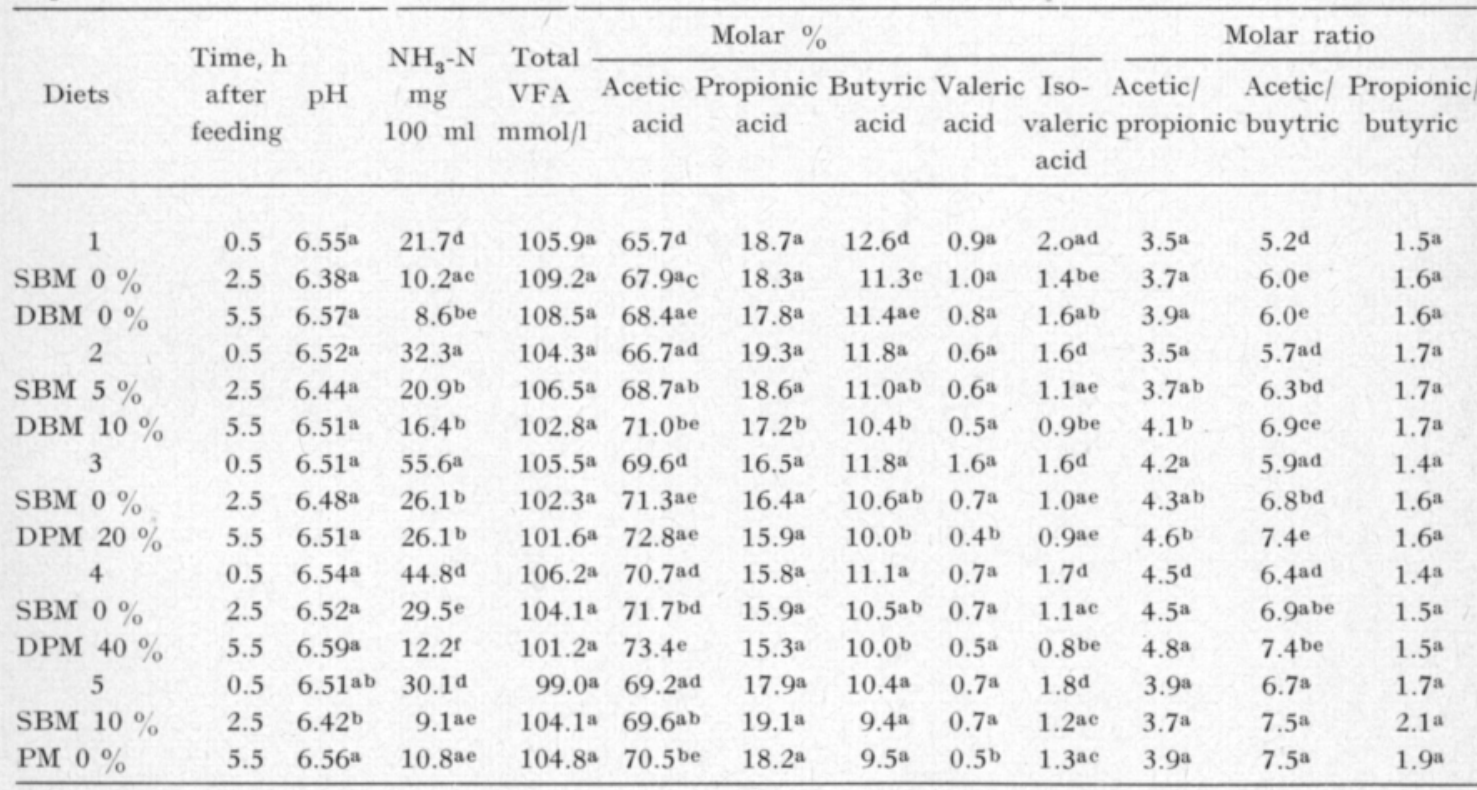


Appendix 6.

The mean number of ciliate $\left(\mathrm{n} \times 10^{3}\right)$ and bacteria $\left(\mathrm{n} \times 10^{9}\right)$ cells per $\mathrm{ml}$ rumen content on different diets.

\begin{tabular}{|c|c|c|c|c|c|c|c|c|c|c|c|c|}
\hline \multirow{2}{*}{$\begin{array}{c}\text { Diets } \\
\text { Time after feeding } \mathrm{h}\end{array}$} & \multicolumn{2}{|c|}{$\begin{array}{l}\text { SBM } \\
10 \%\end{array}$} & $\begin{array}{l}\text { DPM } \\
0 \% \\
\end{array}$ & $\begin{array}{c}\text { SBM } \\
5 \%\end{array}$ & \multicolumn{2}{|c|}{$\begin{array}{l}\text { DPM } \\
10 \%\end{array}$} & $\begin{array}{l}\text { SBM } \\
0 \%\end{array}$ & \multicolumn{2}{|c|}{$\begin{array}{l}\text { DPM } \\
20 \% \\
\end{array}$} & \multicolumn{2}{|c|}{$\begin{array}{l}\text { SBM } \\
0 \%\end{array}$} & $\begin{array}{l}\text { PMM } \\
0 \%\end{array}$ \\
\hline & 0.5 & 2.2 & 5.5 & 0.5 & 2.5 & 5.5 & 0.5 & 2.5 & 5.5 & 0.5 & 2.5 & 5.5 \\
\hline Total ciliates ................. & 248 & 247 & 245 & 351 & 257 & 316 & 725 & 366 & 349 & 410 & 334 & 344 \\
\hline Holotrichs $\ldots \ldots \ldots \ldots \ldots \ldots \ldots$ & 56 & 48 & 59 & 73 & 91 & 89 & 171 & 66 & 55 & 72 & 51 & 70 \\
\hline Isotricha prostoma ........... & 13 & 9 & 15 & 21 & 26 & 44 & 64 & 18 & 25 & 45 & 22 & 21 \\
\hline Dasytricha ruminantam ... & 42 & 39 & 44 & 52 & 65 & 46 & 106 & 49 & 30 & 57 & 29 & 39 \\
\hline Entodiniomorphs ........... & 192 & 199 & 186 & 278 & 166 & 226 & 555 & 299 & 294 & 338 & 283 & 274 \\
\hline Entodinum dubardi ......... & 26 & 28 & 28 & 71 & 23 & 35 & 94 & 46 & 51 & 50 & 32 & 36 \\
\hline E. caudatum .................. & 61 & 56 & 48 & 87 & 42 & 45 & 63 & 31 & 31 & 70 & 60 & 58 \\
\hline E. vorax ......................... & 13 & 10 & 7 & 21 & 18 & 18 & 20 & 12 & 8 & 20 & 13 & 14 \\
\hline E. longinucleatum ........... & 31 & 32 & 31 & 31 & 24 & 51 & 148 & 75 & 79 & 61 & 40 & 43 \\
\hline E. dilobum .................. & 8 & 6 & 4 & 16 & 16 & 16 & 16 & 9 & 9 & 19 & 16 & 17 \\
\hline E. triacum ..................... & 30 & 43 & 36 & 22 & 23 & 31 & 37 & 17 & 15 & 55 & 41 & 40 \\
\hline E. rostratum ..................... & 4 & 6 & 7 & 1 & 0 & 0 & 143 & 84 & 84 & 16 & 34 & 19 \\
\hline E. minimum .................. & 8 & 6 & 7 & 5 & 3 & 5 & 25 & 13 & 13 & 7 & 5 & 6 \\
\hline Eudiplodinum medium .... & 7 & 10 & 15 & 9 & 13 & 17 & 6 & 4 & 4 & 12 & 7 & 9 \\
\hline E. affine ....................... & 1 & 1 & 1 & 14 & 4 & 7 & 2 & 1 & 2 & 26 & 34 & 29 \\
\hline Ostracosinum granile ........ & 2 & 1 & 2 & 0 & 0 & 1 & 1 & 2 & 0 & 2 & 2 & 2 \\
\hline Bacteria & 39 & 37 & 33 & 34 & 30 & 23 & 39 & 33 & 24 & 33 & 23 & 24 \\
\hline
\end{tabular}

